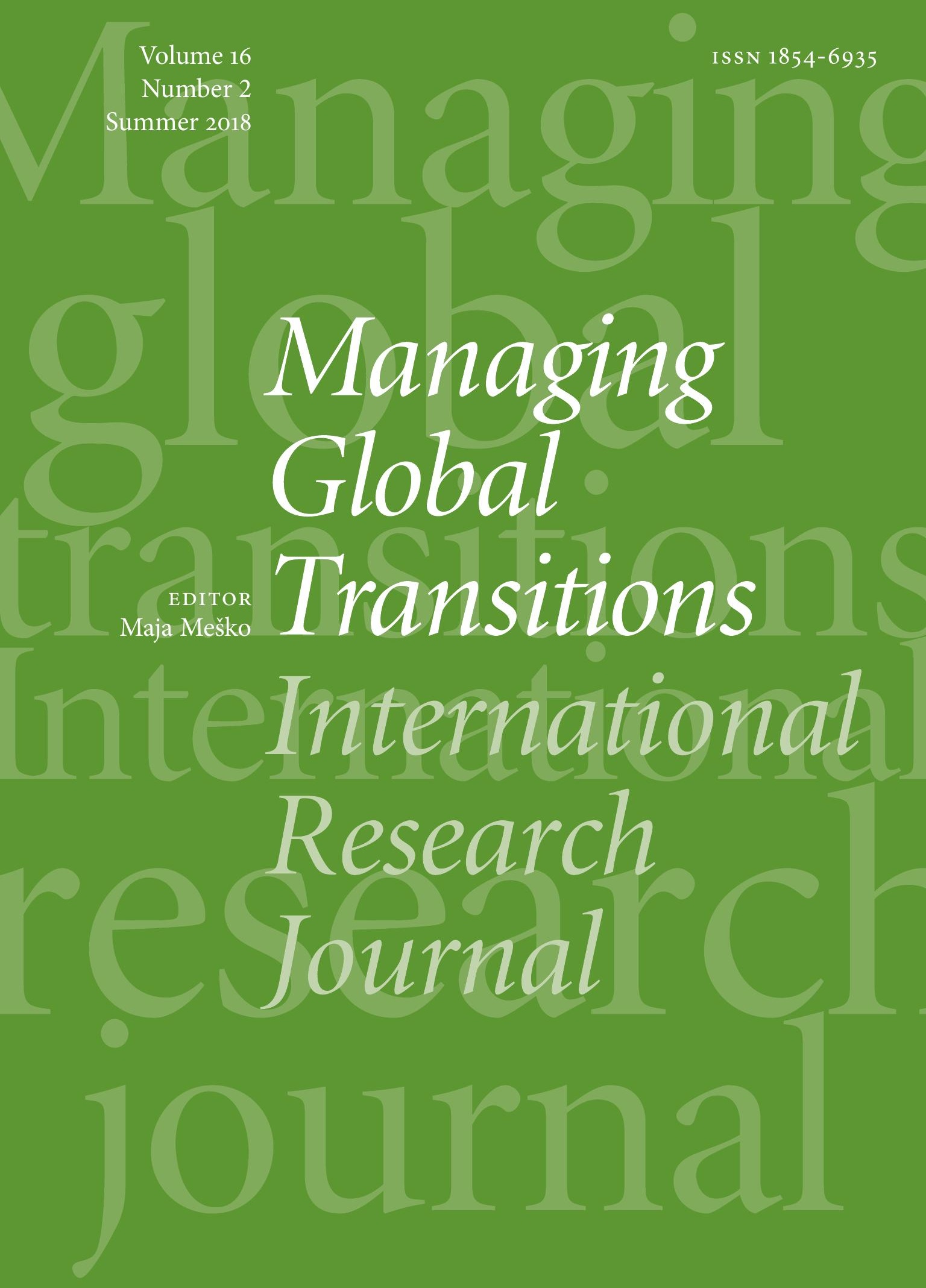




\section{Managing Global Transitions International Research Journal}

ISSN $1854-6935 \cdot$ www.mgt.fm-kp.si

EDITOR

Maja Meško, University of Primorska, Slovenia,maja.mesko@fm-kp.si

ASSOCIATE EDITORS

Andrej Bertoncelj, University of Primorska, Slovenia, andrej.bertoncelj@fm-kp.si

Gandolfo Dominici, University of Palermo, Italy,gandolfo.dominici@libero.it

Alexander Laszlo, Buenos Aires Institute of Technology, Argentina, alaszlo@itba.edu.ar

MANAGING AND PRODUCTION EDITOR

Alen Ježovnik, University of Primorska Press, Slovenia,alen.jezovnik@upr.si

EDITORIAL BOARD

Jani Bekő, Univerza v Mariboru, Slovenia, jani.beko@uni-mb.si

Heri Bezić, University of Rijeka, Croatia, bezic@efri.hr

Guido Bortoluzzi, University of Trieste, Italy, guido.bortoluzzi@deams.units.it

David L. Deeds, University of St. Thomas, usA,david.deeds@gmail.com

Evan Douglas, Griffith Universitiy, Australia, e.douglas@griffith.edu.au

Dean Fantazzini, Moscow School of Economics, Russia, fantazzini@mse-msu.ru

Henryk Gurgul, A GH University of Science and Technology, Poland, henryk.gurgul@gmail.com

András Inotai, Hungarian Academy of Sciences, Hungary, inotai.andras@krtk.mta.hu

Felicetta Iovino, University of Sannio, Italy, fiovino@unisannio.it

Hun Joon Park, Yonsei University, South Korea,hjpark@yonsei.ac.kr

Renata Karkowska, University of Warsaw, Poland,rkarkowska@wz.uw.edu.pl

Tanja Kosi Antolič, Institute of Macroeconomic Analysis and Development, Slovenia, tanja.kosi-antolic@gov.si
Leonard H. Lynn, Case Western Reserve University, UsA, leonard.lynn@case.edu Monty Lynn, Abilene Christian University, USA, monty.lynn@coba.acu.edu

Massimiliano Marzo, University of Bologna, Italy,massimiliano.marzo@unibo.it

Judita Peterlin, University of Ljubljana, Slovenia, judita.peterlin@ef.uni-lj.si

Mirjana Pejić Bach, University of Zagreb, Croatia,mpejic@efzg.hr

Sanja Peković, University of Crna Gora, Montenegro,psanja@ac.me

Sandra Penger, University of Ljubljana, Slovenia,sandra.penger@ef.uni-lj.si

Zdenko Prohaska, University of Rijeka, Croatia, zdenko.prohaska@efri.hr

José Solana Ibánez, Technical University of Cartagena, Spain, jose.solana@cud.upct.es

Marinko Škare, University of Pula, Croatia, mskare@unipu.hr

Nada Trunk Širca, International School of Social and Business Studies, Slovenia, trunk.nada@gmail.com

Šárka Velčovská, Technical University of Ostrava, Czech Republic, sarka.velcovska@vsb.cz

Manfred Weiss, Johann Wolfgang Goethe University, Germany, m.weiss@jur.uni-frankfurt.de

INDEXING AND ABSTRACTING

Managing Global Transitions is indexed/ listed in the International Bibliography of the Social Sciences, EconLit, I z Z Online, DoAJ, Erih Plus, EconPapers, Cabell's, EBsCO, and ProQuest.

SUPPORTED BY

Slovenian Research Agency.

Revija Managing Global Transitions je namenjena mednarodni znanstveni javnosti; izhaja $v$ angleščini s povzetki $v$ slovenščini. Izid revije je finančno podprla Javna agencija za raziskovalno dejavnost Republike Slovenije iz sredstev državnega proračuna iz naslova razpisa za sofinanciranje izdajanja domačih znanstvenih periodičnih publikacij. 


\section{Managing Global Transitions International Research Joumal}

VOLUME 16 - NUMBER 2 - SUMMER 2018 - ISSN 1854-6935

103 Impact of Leadership Styles on Enterprise Success in the Area of Knowledge and Human Resource Management Ivan Miloloža

123 Asymmetric Pass-through Effects from Monetary Policy to Housing Prices in South Africa Andrew Phiri

141 Time-Frequency Analysis of CA P M: Application to the CAC 40 Roman Mestre and Michel Terraza

159 Role of Multidisciplinary and Interdisciplinary Education in Computer Science: A Literature Review Kari-Pekka Heikkinen and Teppo Räisänen

173 Sustainability of the Pension System in the Republic of Macedonia: Challenges and Solutions Hyrije Abazi-Alili, Shpresa Alija, Abdylmenaf Bexheti, Irina B. Panovska, and Remzije Rakipi

189 Abstracts in Slovene 
AIMS AND SCOPE

Managing Global Transitions (MGT) is a quarterly, scholarly journal that covers diverse aspects of transitions and welcomes research on change and innovation in increasingly digitalized and networked economic environments, from a societal, organizational, and technological perspective. MGT fosters the exchange of ideas, experience and knowledge among developed and developing countries with different cultural, organizational and technological traditions. MGT invites conceptual, theorydevelopment, empirical and review papers and case-based studies advancing the field of transitions in societies, organizations and technologies.

\section{TOPICS COVERED}

\section{Transitions in Societies}

- Geo-political transitions, transition experiments, pathways and mechanisms

- Social, demographic, cross-cultural, ethical, geo-political and security aspects of transitions

- Social change, prosperity, wellbeing, happiness

- Policy making, government regulation, social responsibility

- Knowledge-based society and world futures

- New and emerging metrics for measuring, assessing and evaluating societal transitions

\section{Transitions in Organizations}

- Organizational analysis and design, modeling, developments and changes in organizational learning and behavior

- International strategy and strategic alliances, networked businesses and operations

- Entrepreneurship and leadership, decision making

- Knowledge sourcing and innovation management, personal development, education and training, HRM

- Business systems and business models

- Connective intelligence and collective intelligence in organizational behavior
Transitions in Technologies

- Managing technological/organizational change and innovation

- Technology networks, technology transfer benefits and risks, technology acquisition and diffusion

- Smart technologies and development discontinuities, renewable sources and sustainability

- Digitalization, гот, гст, cybernetics, forecasting

- Technological traditions, strategic surprise and response systems

- Studies that promote understanding of the dynamics of socio-technical systems change

- Science and technology policy that fosters transformative advancement

- Modeling technological change in vucA (volatile, uncertain, complex, ambiguous) environments

SUBMISSIONS

The manuscripts should be submitted as e-mail attachment to the editorial office at mgt@fm-kp.si. Detailed guide for authors and publishing ethics statement are available at www.mgt.fm-kp.si.

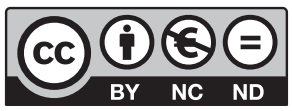

EDITORIAL OFFICE

University of Primorska

Faculty of Management

Cankarjeva 5, 6104 Koper, Slovenia

mgt@fm-kp.si · www.mgt.fm-kp.si

PUBLISHED BY

University of Primorska Press

Titov trg 4, 60oo Koper, Slovenia

zalozba@upr.si·www.hippocampus.si

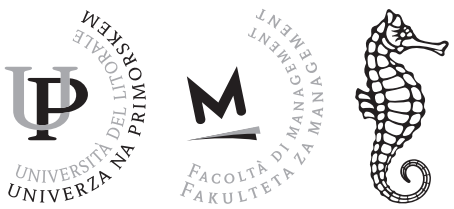




\title{
Impact of Leadership Styles on Enterprise \\ Success in the Area of Knowledge \\ and Human Resource Management
}

\author{
Ivan Miloloža \\ University of Osijek, Croatia \\ ivan.miloloza@fdmz.hr
}

\begin{abstract}
Knowledge and human resources has become the focus of numerous research due to their impact to overall company performance. In addition, the efficiency of management of knowledge and human resources management is driven by numerous factors. The goal of this research is to investigate to what extent the main types of leadership style impact the enterprise success in the area of knowledge and human resources management. Survey on a sample of Croatian companies has been conducted and the relationship between the leadership style and enterprise success in the area of knowledge and human resources management has been examined by the usage of multiple linear regression models.
\end{abstract}

Key Words: leadership style, knowledge management, human resources management, survey, linear regression

JEL Classification: 015

https://doi.org/10.26493/1854-6935.16.103-122

\section{Introduction}

Learning and growth perspective, i.e. knowledge management perspective, creates the foundation necessary to achieve success in the areas of finance, human resources and internal processes. The aims of knowledge management perspective lead to excellent results of other perspectives (Osmanagić-Bedenik 2015).

Knowledge management perspective consists of three categories: human capital, information capital and organizational capital (Nahapiet and Ghoshal 1998). The core tasks of the knowledge management perspective are employee training and progress within organizational culture. Continuous employee development, learning and acquiring new skills within the organization that encourages their work and rewards it contributes considerably to business success (Vrtiprah and Sladoljev 2012; Ženko, Mulej, and Potočan 2017). 
Employees represent the main driving force of growth and development of each enterprise (Rašić, Mulej, and Čančer 2016) Regardless of the use of the latest technological achievements, production of new products or services, enterprises cannot progress without motivated and competent employees. In addition, it is important that enterprises take care of employee satisfaction and reward them in accordance with their commitment and contribution to business development (Terzieva and Morabito 2016). It is necessary to provide further development of skills and competences through lifelong education and learning programs for employees who are willing to engage in teamwork and learning, which will have a positive impact on both employees and further enterprise development.

Information technology is used intensively in knowledge management (Tanriverdi 2005; Varnali 2011; Pejic Bach 2014). The development and progress of the application of the balanced scorecard system led to the need for automation, i.e. for the use of certain software programs during its application (Marr and Neely 2003; Morgado et al. 2014). The three main reasons for applying software programs when implementing the balanced scorecard system are: data integration, data analysis and communication within the enterprise.

In today's business environment characterized by rapid changes and adaptations to international markets, management needs to be changed or adapted to new business conditions as well (Bennis 2007), such as social media (Roblek et al. 2013). Nowadays, enterprises are focused mostly on customers, employees and constant introducing of innovations in order to be able to compete with their competitors and respond to market demands successfully (Verhoef 2003). Leadership is precisely the main factor in managing enterprises during the time of change, but also during problem solving, since only the leader is capable of creating an environment in which their associates are encouraged to be leaders, cooperate with each other and develop themselves, which contributes to the enterprise development (Sherehiy, Karwowski, and Layer 2007).

Leaders contribute to the organization success on several levels: managing change, directing associates, managing towards accomplishing set goals, encouraging others to maximize their skills and competences (Bouckenooghe, Zafar, and Raja 2015). They play an important role in international business because they encourage the creation of effective teams, increase efficiency and productivity, motivate associates, coordinate activities within several organizational units and contribute significantly to the enterprise success (Fragouli 2016). 
Behaviour-based leadership includes several types of leadership: leadership based on the use of authority, Likert's leadership systems, taskoriented leadership, leadership continuity (Renko et al. 2015). Leadership based on the use of authority, i.e. power, includes three basic styles: autocratic, democratic and laissez-faire leader (Mehta 2016). The autocratic leader is a person who manages others by a system of awards and punishments, communicates by ordering and commanding and seeks subordination of their associates. The democratic leader cooperates intensively with their associates and encourages their participation in making and implementing decisions. The laissez-faire leader gives almost full independence to their associates. The aim of this paper is to examine the correlation between enterprise success and leadership styles.

\section{Measuring Knowledge Management}

Improving the employees' knowledge and skills, as well as the rewarding system, increases employee satisfaction and motivation considerably, which also has a positive impact on the business of the enterprise (Križmarić 2014). The perspective of learning and growth is a key factor, as it defines the key competences and skills, technology and corporate culture that is needed to support the successful realization of enterprise's strategy (Osmanagić-Bedenik 2015).

The aims of learning and growth perspective include alignment of human potentials and technology with its own strategy. Each enterprise needs to determine the way to harmonize the requirements of key internal processes and management of employees' relations and career. The importance of investing in human potentials, through their progress and learning, represents the key enterprise resource.

During the implementation of measuring the balanced scorecard system, the enterprises are focused mostly on three areas (Kaplan and Norton 2001):

1. Capacity of employees - measured by employee satisfaction, productivity, formal education, further development.

2. Information system - provides access to accurate, timely and highquality information.

3. Alignment of individual interests with enterprise's interests - enterprise's employees need to be familiar with enterprise's goals in order to participate in their realization.

In the knowledge management perspective, monitoring success in the 
development of enterprise's strategic capability and intellectual capital is performed (Wiig 1997; Von Krogh, Nonaka, and Rechsteiner 2012). It can be noticed that the basic indicators are: (i) employee retention, (ii) employee satisfaction, and (iii) employee productivity. The business foundation and realization of the results are made of: employee competency, technological infrastructure and a comfortable working environment, i.e. a motivating organizational climate.

INDICATORS FOR MEASURING EMPLOYEE COMPETENCY

When selecting indicators for measuring employee competency, it is important to define what key skills and resources the enterprise needs to implement the strategy and what competencies the enterprise currently possesses, as well as what makes the difference and how big that difference is (Spee and Jarzabkowski 2011). Furthermore, it is important to invest in further development and improvement of employees through lifelong learning programs (Blaschke 2012).

\section{INDICATORS FOR MEASURING INFORMATION SYSTEM POTENTIALS}

One of the main factors, which is increasingly becoming the most important key to the enterprise success in today's global economy, is information and communication technology. Access and use of timely and highquality information with developed IT infrastructure represent the competitive advantage of the enterprise (Lew and Sinkovics 2013). Enterprises that do not want to lag behind the competition but be market leaders instead must invest in the development and implementation of information and communication technologies.

Indicators for measuring information system potentials are used to measure the percentage of employees who have access to necessary information at a given time, as well as when assessing the potential of information systems in relation to enterprise's needs.

INDICATORS FOR MEASURING MOTIVATION, COMPETENCE AND GOAL-ORIENTATION

Employee motivation is linked considerably to organizational culture and working environment, i.e. to workplace satisfaction (Moon 2000). Employee satisfaction indicators are collected through an employee questionnaire. The most common form of conducting a questionnaire is via intranet or e-mail. 
Parmenter (2010) states the following measures for managing the learning and development perspective successfully: (i) Investments in training, (ii) Working life, (iii) \% of employees with graduate degree and $\%$ of employees to be reclassified, (iv) Fluctuation rate, (v) Employee productivity, (vi) Number of years of manager's work experience, (vii) Quality of the working environment, (viii) Achievement of personal goals and (ix) Violation of ethics.

\section{Measuring Leadership Styles}

Scientists who supported behavior-based leadership theories tried to define the best leadership style that would be effective in all situations, which led to several theories and leadership models such as: autocratic, democratic and laissez-faire leadership style. Given the advantages and disadvantages that exist in all three leadership styles, one can conclude that there is no single best leadership style, but that leaders must adapt to the situation and associates in order to achieve the best result.

\section{Research Methodology}

The Leadership Styles Questionnaire, taken from the book Introduction to Leadership by Northouse (2012) was used as a research instrument. In addition, a questionnaire for measuring enterprise success in terms of four dimensions of success was used.

Leadership styles in the organizations from the sample were measured by using the attached questionnaire in which the autocratic, democratic and laissez-faire leadership style were measured by using certain claims. The Leadership Styles Questionnaire was taken from the book Introduction to Leadership by Northouse (2012). Respondents indicated on a scale of 1 to 5 to what extent they agree with each claim.

Claims that measure the presence of an autocratic leadership style are:

- L1 Employees need to be supervised closely, or they are not likely to do their work.

- L4 It is fair to say that most employees in the general population are lazy.

- L7 As a rule, employees must be given rewards or punishments in order to motivate them to achieve organizational objectives.

- L10 Most employees feel insecure about their work and need direction. 
- L13 The leader is the chief judge of the achievements of the members of the group.

- L16 Effective leaders give orders and clarify procedures.

Claims that measure the presence of a democratic leadership style are:

- L2 Employees want to be a part of the decision-making process.

- L5 Providing guidance without pressure is the key to being a good leader.

- L8 Most workers want frequent and supportive communication from their leader.

- L11 Leaders need to help subordinates accept responsibility for completing their work.

- L14 It is the leader's job to help subordinates find their 'passion.'

- L17 People are basically competent and if given a task will do a good job.

Claims that measure the presence of laissez-faire leadership style are:

- L3 In complex situations, leaders should let subordinates work problems out on their own.

- L6 Leadership requires staying out of the way of subordinates as they do their work.

- L9 As a rule, leaders should allow subordinates to appraise their own work.

- L12 Leaders should give subordinates complete freedom to solve problems on their own.

- L15 In most situations, workers prefer little input from the leader.

- L18 In general, it is best to leave subordinates alone.

MEASURING THE SUCCESS OF THE SAMPLE ORGANIZATIONS

Measuring the success of the sample organizations was conducted by using a questionnaire that measures the enterprise success in relation to its competitors in its core business area, given the financial, process and market dimension of success and the knowledge management success. The respondents indicated on a scale of 1 to 5 to what extent they agree with the claim that their enterprise is better than the competition in the business.

The process dimensions of success are:

- P1 Efficiency of internal processes. 
TABLE 1 Success of All Enterprises Together Measured by the Balanced Scorecard System from the Field of Knowledge Management

\begin{tabular}{lrrrrrr}
\hline Item & $(1)$ & $(2)$ & $(3)$ & $(4)$ & $(5)$ & $(6)$ \\
\hline Z1 Employee competency & 60 & 3 & 5 & 4.017 & 0.624 & 0.679 \\
Z2 Application of new technologies & 60 & 2 & 5 & 4.017 & 0.854 & \\
Z3 Organizational climate & 60 & 2 & 5 & 4.017 & 0.748 & \\
Knowledge & 60 & 2.333 & 5.000 & 4.017 & 0.584 & \\
\hline
\end{tabular}

notes (1) $N$, (2) min, (3) max, (4) average, (5) standard deviation, (6) Cronbach's alpha.

- P2 Innovation of products/services.

- P3 Innovation of internal processes.

The research unit is an enterprise registered in the Republic of Croatia, and the population consists of the collection of all such enterprises. The Croatian Chamber of Economy represents the framework of the sampling, from which the sample of enterprises will be chosen randomly. The respondent is the president or an executive board member of the enterprise, and the enterprises will be contacted by phone in advance to establish contact and explain the purpose, but also the confidentiality of the research results, as well as their use for scientific purposes only. The survey was conducted on a stratified sample of 60 enterprises total divided into 6 sub-groups. Of this, there were: (1) 10 small and medium-sized enterprises in the growth phase (sub-code: SME-growth); (2) 10 small and medium-sized enterprises in the maturity phase (sub-code: SMEmaturity); (3) 10 small and medium-sized enterprises in the stagnation phase (sub-code: SME-stagnation); (4) 10 large enterprises in the growth phase (sub-code: Large-growth); (5) 10 large enterprises in the maturity phase (sub-code: Large-maturity) and (6) 10 large enterprises in the stagnation phase (sub-code: Large-stagnation).

Table 1 shows the answers of the respondents - managers who are members of the board of directors - to questions by which they evaluated the success of all enterprises measured together by the balanced scorecard system, with the average answers of the respondents from all enterprises being compared. The respondents agree mostly with the item P2. Product/service innovation within the dimension Process success (average rating 4.00).

Figure 1 shows the comparison of average ratings of the presence of leadership styles in all enterprises together. The respondents agree mostly with the attitudes that reflect democratic leadership style (the highest av- 


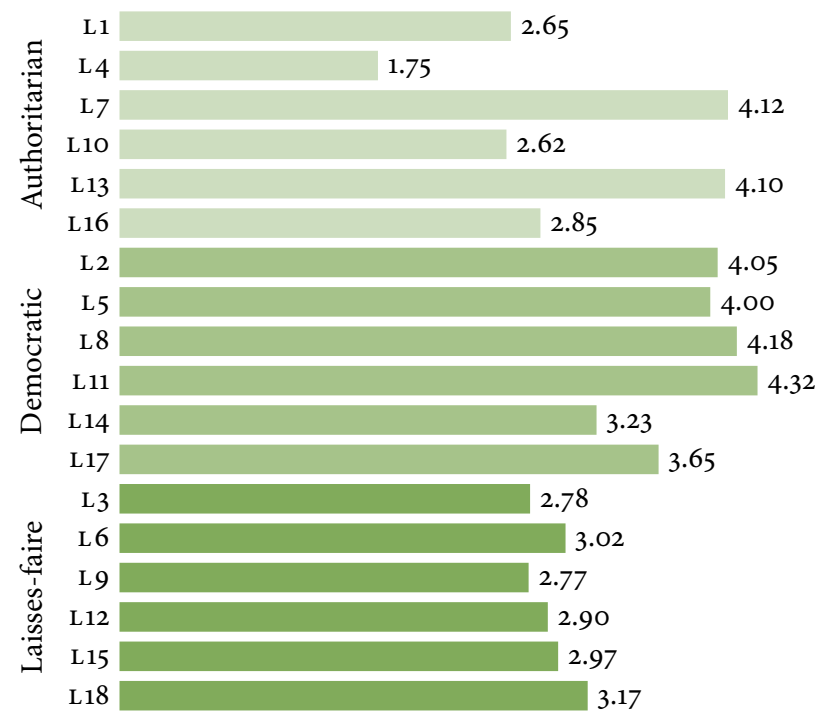

FIGURE 1 Comparison of Average Ratings of the Presence of Leadership Styles in All Enterprises Together

erage ratings are noticed), while they agree the least with the attitudes that reflect laissez-faire leadership style (the lowest average ratings are recorded).

\section{Results}

IMPACT OF LEADERSHIP STYLES ON ALL ENTERPRISES

TOGETHER

Table 2 shows a regression model with the dependent variable Knowledge and employees. All items of measuring leadership styles, which refer to autocratic, democratic and laissez-faire style, were used as independent variables. Step-wise multiple regression analysis was used to form the model. A model with a determination coefficient of 0.381 was established, indicating that the selected model implied $38.1 \%$ deviation from the dependent variable.

There are two statistically significant independent variables in the model that reflect autocratic style L 4. It is fair to say that most employees in the general population are lazy (statistically significant at $1 \%$ level) and L10. Most employees feel insecure about their work and need direction (statistically significant at $1 \%$ level). Variables $\mathrm{L} 4$ and L1o have a negative impact on the dependent variable Knowledge and employees in all enterprises. 
TABLE 2 Regression Model with the Dependent Variable Knowledge and Employees and the Independent Variables Items of Leadership Styles (All Enterprises Together)

\begin{tabular}{llrrrrl}
\hline Style & Variable & $(1)$ & $(2)$ & $(3)$ & $(4)$ & $(5)$ \\
\hline Constant & & 5.391 & 0.404 & & 13.346 & $0.000^{\star * *}$ \\
\hline Autocratic & L4 & -0.187 & 0.061 & -0.343 & -3.050 & $0.004^{\star * *}$ \\
& L10 & -0.213 & 0.059 & -0.404 & -3.600 & $0.001^{\star * *}$ \\
\hline Democratic & L11 & -0.171 & 0.078 & -0.252 & -2.199 & $0.032^{\star *}$ \\
\hline Laissez-faire & L12 & -0.129 & 0.060 & -0.253 & -2.130 & $0.038^{\star *}$ \\
& L18 & 0.161 & 0.061 & 0.309 & 2.636 & $0.011^{\star *}$ \\
\hline
\end{tabular}

Notes $R^{2}=0.381$, Adjusted $R^{2}=0.324$. Column headings are as follows: (1) nonstandardized coefficients, (2) standard error, (3) standardized coefficients, (4) $t$, (5) $p$ values. ${ }^{\star} p<0.1,{ }^{* *} p<0.05,{ }^{* * *} p<0.01$.

There is one statistically significant independent variable in the model that reflects democratic style L11. Leaders need to help subordinates accept responsibility for completing their work (statistically significant at $5 \%$ level). Variable $\mathrm{L} 11$ has a negative impact on the dependent variable Knowledge and employees in all enterprises.

There are two statistically significant independent variables in the model that reflect laissez-faire style L12. Leaders should give subordinates complete freedom to solve problems on their own (statistically significant at $5 \%$ level) and L18. In general, it is best to leave subordinates alone (statistically significant at $5 \%$ level). Variable $\mathrm{L} 12$ has a negative impact on the dependent variable Knowledge and employees in all enterprises, while variable $\mathrm{L} 18$ has a positive impact.

\section{IMPACT OF LEADERSHIP STYLES ON SMALL}

\section{AND MEDIUM-SIZED ENTERPRISES}

Table 3 shows a regression model with the dependent variable Knowledge and employees in SME enterprises. All items of measuring leadership styles, which refer to autocratic, democratic and laissez-faire style, were used as independent variables. Step-wise multiple regression analysis was used to form the model. A model with a determination coefficient of 0.267 was established, indicating that the selected model implied $26.7 \%$ deviation from the dependent variable.

There is only one statistically significant independent variable in the model that reflects autocratic style L10. Most employees feel insecure about their work and need direction (statistically significant at $1 \%$ level). 
TAB LE 3 Regression Model with the Dependent Variable Knowledge and Employees and the Independent Variables Items of Leadership Styles in Relation to the Size of the Enterprise - SME

\begin{tabular}{llrrrrl}
\hline Style & Variable & $(1)$ & $(2)$ & $(3)$ & $(4)$ & $(5)$ \\
\hline Constant & & 3.972 & 0.416 & & 9.544 & $0.000^{* * *}$ \\
\hline Autocratic & L10 & -0.200 & 0.071 & -0.465 & -2.797 & $0.009^{* * *}$ \\
\hline Democratic & L5 & 0.162 & 0.091 & 0.295 & 1.773 & $0.087^{*}$
\end{tabular}

NOTES $R^{2}=0.267$, Adjusted $R^{2}=0.212$. Column headings are as follows: (1) nonstandardized coefficients, (2) standard error, (3) standardized coefficients, (4) $t$, (5) $p$ values. ${ }^{\star} p<0.1,{ }^{* *} p<0.05,{ }^{* *} p<0.01$.

Variable L10 has a negative impact on the dependent variable Knowledge and employees in SME enterprises.

There is only one statistically significant independent variable in the model that reflects democratic style $\mathrm{L} 5$. Providing guidance without pressure is the key to being a good leader (statistically significant at $5 \%$ level). Variable $\mathrm{L} 5$ has a positive impact on the dependent variable Knowledge and employees in SME enterprises.

\section{IMPACT OF LEADERSHIP STYLES ON LARGE ENTERPRISES}

Table 4 shows a regression model with the dependent variable Knowledge and employees. All items of measuring leadership styles, which refer to autocratic, democratic and laissez-faire style, were used as independent variables. Step-wise multiple regression analysis was used to form the model. A model with a determination coefficient of 0.796 was established, indicating that the selected model implied $79.6 \%$ deviation from the dependent variable.

There are three statistically significant independent variables in the model that reflect autocratic style L1. Employees need to be supervised closely, or they are not likely to do their work (statistically significant at $5 \%$ level), L4. It is fair to say that most employees in the general population are lazy (statistically significant at $1 \%$ level) and L13. The leader is the chief judge of the achievements of the members of the group (statistically significant at $1 \%$ level). Variables L1 and L13 have a positive impact on the dependent variable Knowledge and employees in large enterprises, while variable $\mathrm{L} 4$ has a negative impact.

There are two statistically significant independent variables in the model that reflect democratic style $\mathrm{L}_{5}$. Providing guidance without pressure is the key to being a good leader (statistically significant at 1\% level) 
TA B LE 4 Regression Model with the Dependent Variable Knowledge and Employees and the Independent Variables Items of Leadership Styles in Relation to the Size of the Enterprise - SME

\begin{tabular}{llrrrrl}
\hline Style & Variable & $(1)$ & $(2)$ & $(3)$ & $(4)$ & $(5)$ \\
\hline Constant & & 2.921 & 0.673 & & 4.339 & $0.000^{* * *}$ \\
\hline Autocratic & L1 & 0.202 & 0.088 & 0.374 & 2.298 & $0.032^{* *}$ \\
& L4 & -0.459 & 0.086 & -0.875 & -5.325 & $0.000^{* * *}$ \\
& L13 & 0.379 & 0.096 & 0.435 & 3.971 & $0.001^{* * *}$ \\
\hline Democratic & L5 & 0.256 & 0.075 & 0.417 & 3.413 & $0.003^{* * *}$ \\
& L17 & -0.594 & 0.112 & -0.612 & -5.321 & $0.000^{* * *}$ \\
\hline Laissez-faire & L3 & 0.200 & 0.058 & 0.407 & 3.430 & $0.003^{* * *}$ \\
& L6 & 0.133 & 0.076 & 0.213 & 1.754 & $0.095^{*}$ \\
& L9 & 0.204 & 0.073 & 0.329 & 2.778 & $0.012^{* *}$ \\
& L12 & -0.124 & 0.063 & -0.211 & -1.959 & $0.064^{*}$ \\
\hline
\end{tabular}

NOtes $R^{2}=0.796$, Adjusted $R^{2}=0.705$. Column headings are as follows: (1) nonstandardized coefficients, (2) standard error, (3) standardized coefficients, (4) $t$, (5) $p$ values. ${ }^{\star} p<0.1,{ }^{* *} p<0.05,{ }^{* *} p<0.01$.

and L17. People are basically competent and if given a task will do a good job (statistically significant at $1 \%$ level). Variable $\mathrm{L}_{5}$ has a positive impact on the dependent variable Knowledge and employees in large enterprises, while variable $\mathrm{L} 17$ has a negative impact.

There are four statistically significant independent variables in the model that reflect laissez-faire style L3. In complex situations, leaders should let subordinates work problems out on their own (statistically significant at $1 \%$ level), L6. Leadership requires staying out of the way of subordinates as they do their work (statistically significant at $10 \%$ level), L9. As a rule, leaders should allow subordinates to appraise their own work (statistically significant at 5\% level) and L12. Leaders should give subordinates complete freedom to solve problems on their own (statistically significant at 10\% level). Variables L3, L6 and L9 have a positive impact on the dependent variable Knowledge and employees in large enterprises, while variable $\mathrm{L} 12$ has a negative impact.

\section{IMPACT OF LEADERSHIP STYLES ON ENTERPRISES IN GROWTH AND MATURITY PHASE (LEADERS)}

There are two statistically significant independent variables in the model that reflect autocratic style L 4 . It is fair to say that most employees in the 
general population are lazy (statistically significant at $1 \%$ level) and L7. As a rule, employees must be given rewards or punishments in order to motivate them to achieve organizational objectives (statistically significant at $1 \%$ level). Variables $\mathrm{L} 4$ and $\mathrm{L} 7 \mathrm{have}$ a negative impact on the dependent variable Knowledge and employees in market leader enterprises.

There are two statistically significant independent variables in the model that reflect democratic style $\mathrm{L} 8$. Most workers want frequent and supportive communication from their leader (statistically significant at $5 \%$ level) and L17. People are basically competent and if given a task will do a good job (statistically significant at $1 \%$ level). Variables L 8 and L17 have a negative impact on the dependent variable Knowledge and employees in market leader enterprises.

There are four statistically significant independent variables in the model that reflect laissez-faire style $\mathrm{L} 6$. Leadership requires staying out of the way of subordinates as they do their work (statistically significant at $5 \%$ level), L9 As a rule, leaders should allow subordinates to appraise their own work (statistically significant at 10\% level), L12. Leaders should give subordinates complete freedom to solve problems on their own (statistically significant at $1 \%$ level) and L18 In general, it is best to leave subordinates alone (statistically significant at $10 \%$ level). Variable L12 has a negative impact on the dependent variable Knowledge and employees in market leader enterprises, while variables L6, L9 and L18 have a positive impact.

\section{IMPACT OF LEADERSHIP STYLES ON ENTERPRISES \\ IN STAGNATION PHASE (FOLLOWERS)}

Table 6 shows a regression model with the dependent variable Knowledge and employees in enterprises in stagnation phase (followers). All items of measuring leadership styles, which refer to autocratic, democratic and laissez-faire style, were used as independent variables. Step-wise multiple regression analysis was used to form the model. A model with a determination coefficient of 0.724 was established, indicating that the selected model implied $72.4 \%$ deviation from the dependent variable.

There are three statistically significant independent variables in the model that reflect autocratic style L7. As a rule, employees must be given rewards or punishments in order to motivate them to achieve organizational objectives (statistically significant at 10\% level), L10. Most employees feel insecure about their work and need direction (statistically significant at $10 \%$ level) and L13. The leader is the chief judge of the achievements of the members of the group (statistically significant at $5 \%$ level). 
TAB LE 5 Regression Model with the Dependent Variable Knowledge and Employees and the Independent Variables Items of Leadership Styles in Relation to the Growth Phase of the Enterprise - Enterprises in Growth and Maturity Phase (Leaders)

\begin{tabular}{llrrrrl}
\hline Style & Variable & $(1)$ & $(2)$ & $(3)$ & $(4)$ & $(5)$ \\
\hline Constant & & 7.668 & 0.763 & & 10.049 & $0.000^{* * *}$ \\
\hline Autocratic & L4 & -0.408 & 0.087 & -0.664 & -4.685 & $0.000^{* * *}$ \\
& L7 & -0.218 & 0.069 & -0.367 & -3.146 & $0.004^{* * *}$ \\
\hline Democratic & L8 & -0.245 & 0.101 & -0.315 & -2.414 & $0.023^{* *}$ \\
& L17 & -0.305 & 0.089 & -0.411 & -3.418 & $0.002^{* * *}$ \\
\hline Laissez-faire & L6 & 0.182 & 0.080 & 0.311 & 2.280 & $0.031^{* *}$ \\
& L9 & 0.120 & 0.062 & 0.218 & 1.944 & $0.062^{*}$ \\
& L12 & -0.380 & 0.063 & -0.708 & -6.062 & $0.000^{* * *}$ \\
& L18 & 0.129 & 0.073 & 0.235 & 1.763 & $0.089^{*}$
\end{tabular}

NOTES $R^{2}=0.700$, Adjusted $R^{2}=0.611$. Column headings are as follows: (1) nonstandardized coefficients, (2) standard error, (3) standardized coefficients, (4) $t$, (5) $p$ values. ${ }^{*} p<0.1,{ }^{* *} p<0.05,{ }^{* *} p<0.01$.

Variables L7 and L13 have a positive impact on the dependent variable Knowledge and employees in Following enterprises on the market, while variable $\mathrm{L} 10$ has a negative impact.

There is only one statistically significant independent variable in the model that reflects democratic style $\mathrm{L} 17$. People are basically competent and if given a task will do a good job (statistically significant at $5 \%$ level). Variable L17 has a positive impact on the dependent variable Knowledge and employees in Following enterprises on the market.

There are two statistically significant independent variables in the model that reflect laissez-faire style L3. In complex situations, leaders should let subordinates work problems out on their own (statistically significant at $1 \%$ level) and L15. In most situations, workers prefer little input from the leader (statistically significant at $1 \%$ level). Variables $\mathrm{L} 3$ and L15 have a positive impact on the dependent variable Knowledge and employees in Following enterprises on the market.

IMPACT OF LEADERSHIP STYLES ON ENTERPRISES ORIENTED TOWARDS DOMICILE MARKETS

There are four statistically significant independent variables in the model that reflect autocratic style L1. Employees need to be supervised closely, or they are not likely to do their work (statistically significant at 1\% level), 
TAB LE 6 Regression Model with the Dependent Variable Knowledge and Employees and the Independent Variables Items of Leadership Styles in Relation the Growth Phase of the Enterprise - Enterprises in Stagnation Phase (Followers)

\begin{tabular}{llrrrrr}
\hline Style & Variable & $(1)$ & $(2)$ & $(3)$ & $(4)$ & $(5)$ \\
\hline Constant & & 0.120 & 0.848 & & 0.142 & 0.889 \\
\hline Autocratic & L7 & 0.124 & 0.069 & 0.235 & 1.799 & $0.090^{*}$ \\
& L10 & -0.131 & 0.070 & -0.279 & -1.879 & $0.077^{*}$ \\
& L13 & 0.242 & 0.096 & 0.387 & 2.526 & $0.022^{\star *}$ \\
\hline Democratic & L17 & 0.268 & 0.093 & 0.444 & 2.890 & $0.010^{\star *}$ \\
\hline Laissez-faire & L3 & 0.311 & 0.065 & 0.726 & 4.812 & $0.000^{\star * *}$ \\
& L15 & 0.256 & 0.064 & 0.556 & 4.006 & $0.001^{\star * *}$
\end{tabular}

NOtes $R^{2}=0.724$, Adjusted $R^{2}=0.627$. Column headings are as follows: (1) nonstandardized coefficients, (2) standard error, (3) standardized coefficients, (4) $t$, (5) $p$ values. ${ }^{*} p<0.1,{ }^{* *} p<0.05,{ }^{* *} p<0.01$.

L4 It is fair to say that most employees in the general population are lazy (statistically significant at 5\% level), L10. Most employees feel insecure about their work and need direction (statistically significant at $1 \%$ level) and L13. The leader is the chief judge of the achievements of the members of the group (statistically significant at $5 \%$ level). Variables $\mathrm{L} 1$ and L13 have a positive impact on the dependent variable Knowledge and employees in enterprises (which are) oriented predominantly towards domestic market, while variables $\mathrm{L} 4$ and L1o have a negative impact.

There are two statistically significant independent variables in the model that reflect democratic style $\mathrm{L}_{5}$ Providing guidance without pressure is the key to being a good leader (statistically significant at $1 \%$ level) and L14 It is the leader's job to help subordinates find their 'passion' (statistically significant at $1 \%$ level). Variable $\mathrm{L}_{5}$ has a positive impact on the dependent variable Knowledge and employees in enterprises (which are) oriented predominantly towards domestic market, while variables L14 has a negative impact.

IMPACT OF LEADERSHIP STYLES ON ENTERPRISES ORIENTED TOWARDS INTERNATIONAL MARKETS

Table 8 shows a regression model with the dependent variable Knowledge and employees in enterprises oriented predominantly towards foreign market. All items of measuring leadership styles, which refer to autocratic, democratic and laissez-faire style, were used as independent vari- 
TABLE 7 Regression Model with the Dependent Variable Knowledge and Employees and the Independent Variables Items of Leadership Styles in Relation to the International Orientation of the Enterprise - Predominantly Domestic Market

\begin{tabular}{llrrrrl}
\hline Style & Variable & $(1)$ & $(2)$ & $(3)$ & $(4)$ & $(5)$ \\
\hline Constant & & 3.501 & 0.513 & & 6.825 & $0^{\circ .000^{* * *}}$ \\
\hline Autocratic & L1 & 0.218 & 0.058 & 0.452 & 3.786 & $0.001^{* * *}$ \\
\hline \multirow{2}{*}{ L4 } & -0.116 & 0.056 & -0.237 & -2.064 & $0.047^{* *}$ \\
& L10 & -0.187 & 0.063 & -0.357 & -2.964 & $0.006^{* * *}$ \\
& L13 & 0.182 & 0.079 & 0.249 & 2.289 & $0.029^{* *}$ \\
\hline Democratic & L5 & 0.215 & 0.062 & 0.383 & 3.496 & $0.001^{* * *}$ \\
& L14 & -0.306 & 0.072 & -0.508 & -4.241 & $0.000^{* * *}$
\end{tabular}

Notes $R^{2}=0.669$, Adjusted $R^{2}=0.605$. Column headings are as follows: (1) nonstandardized coefficients, (2) standard error, (3) standardized coefficients, (4) $t$, (5) $p$ values. ${ }^{*} p<0.1,{ }^{* *} p<0.05,{ }^{* *} p<0.01$.

ables. Step-wise multiple regression analysis was used to form the model. A model with a determination coefficient of 0.762 was established, indicating that the selected model implied $76.2 \%$ deviation from the dependent variable.

There are two statistically significant independent variables in the model that reflect autocratic style L10. Most employees feel insecure about their work and need direction (statistically significant at 1\% level) and L16. Effective leaders give orders and clarify procedures (statistically significant at $5 \%$ level). Variable $\mathrm{L} 16$ has a positive impact on the dependent variable Knowledge and employees in enterprises oriented predominantly towards foreign market, while variable L1o has a negative impact.

There are two statistically significant independent variable in the model that reflects democratic style L8. Most workers want frequent and supportive communication from their leader (statistically significant at $1 \%$ level) and L14. It is the leader's job to help subordinates find their 'passion' (statistically significant at 1\% level). Variables L 8 and L14 have a positive impact on the dependent variable Knowledge and employees in enterprises oriented predominantly towards foreign market.

There are two statistically significant independent variables in the model that reflect laissez-faire style L9. As a rule, leaders should allow subordinates to appraise their own work (statistically significant at $1 \%$ level) and L15. In most situations, workers prefer little input from the 
TAB LE 8 Regression Model with the Dependent Variable Knowledge and Employees and the Independent Variables Items of Leadership Styles in Relation to the International Orientation of the Enterprise - Predominantly Foreign Market

\begin{tabular}{llrrrrl}
\hline Style & Variable & $(1)$ & $(2)$ & $(3)$ & $(4)$ & $(5)$ \\
\hline Constant & & -2.052 & 1.154 & & -1.778 & \multicolumn{1}{c}{$0.096^{*}$} \\
\hline Autocratic & L10 & -0.328 & 0.080 & -0.604 & -4.096 & $0.001^{\star * *}$ \\
& L16 & 0.213 & 0.093 & 0.473 & 2.291 & $0.037^{\star *}$ \\
\hline Democratic & L8 & 0.581 & 0.159 & 0.541 & 3.646 & $0.002^{\star * *}$ \\
& L14 & 0.448 & 0.131 & 0.568 & 3.426 & $0.004^{* * *}$ \\
& L9 & 0.514 & 0.122 & 0.795 & 4.226 & $0.001^{\star * *}$ \\
\hline Laissez-faire & L15 & 0.375 & 0.110 & 0.535 & 3.398 & $0.004^{* * *}$
\end{tabular}

NOtes $R^{2}=0.762$, Adjusted $R^{2}=0.666$. Column headings are as follows: (1) nonstandardized coefficients, (2) standard error, (3) standardized coefficients, (4) $t$, (5) $p$ values. ${ }^{\star} p<0.1,{ }^{* *} p<0.05,{ }^{* *} p<0.01$.

leader (statistically significant at 1\% level). Variables L9 and L15 have a positive impact on the dependent variable Knowledge and employees in enterprises oriented predominantly towards foreign market.

\section{Discussion and Conclusion}

Table 9 shows the impact of different leadership styles on the aggregate process success variable. The last three lines show the aggregate impact of a particular leadership style.

\section{AUTOCRATIC LEADERSHIP STYLE}

It can be noticed that variable $\mathrm{L} 1$ has a statistically significant positive impact on the variable of knowledge management success for large enterprises and enterprises oriented towards domestic market, and the same goes for variable L13 and large enterprises, as well as those in the stagnation phase and those oriented towards domestic market. On the other hand, variable L1o has a negative impact on virtually all enterprises, except on large enterprises and enterprises in the maturity phase, which is also true for variable L4, except for small enterprises, enterprises in the stagnation phase and enterprises oriented towards international market.

\section{DEMOCRATIC LEADERSHIP STYLE}

It can be noticed that the variable $\mathrm{L} 5$ has a statistically significant positive impact on the variable of knowledge management success for small 
and large enterprises and enterprises oriented towards domestic market. Variable L11 has a negative impact on all enterprises.

\section{LAISSEZ-FAIR LEADERSHIP STYLE}

It can be noticed that the variables related to laissez-faire leadership style have almost entirely positive impact on the variable of knowledge management success. Variable $\mathrm{L}_{3}$ has a statistically significant positive impact on large enterprises and enterprises in the stagnation phase, and the same goes for variables L 6 and L9 for large enterprises and enterprises in the maturity phase. On the other hand, only variable $\mathrm{L} 12$ has a negative impact on the aggregate variable of knowledge management success, on large enterprises and on enterprises in the maturity phase.

\section{Conclusion}

The research results point to the following differences in the knowledge management success. For the purpose of the conclusion, only the difference in the aggregate variable of knowledge management success will be analysed. The influence of the autocratic style is as follows: (i) a negative impact is present in small enterprises and enterprises in the growth and maturity phase; (ii) a neutral impact is present in enterprises oriented towards international and domicile markets, (iii) a positive impact has been made in large enterprises and enterprises in the stagnation phase. The impact of the democratic style is as follows: (i) a negative impact is present in enterprises in the growth and maturity phase; (ii) a neutral impact is present in large enterprises and enterprises oriented towards domicile market; (iii) a positive impact is present in small and mediumsized enterprises, enterprises in the stagnation phase and enterprises oriented towards international markets. The impact of the laissez-faire style is that: (i) a negative impact is not present in any enterprise group; (ii) a neutral impact is present in small and medium-sized enterprises and enterprises oriented predominantly towards domicile markets, and (iii) a positive impact is present in large enterprises, enterprises in the maturity and growth phase, as well as in enterprises in the stagnation phase. It can be concluded that: (i) small enterprises are more successful in knowledge management in the presence of democratic style, while autocratic style has a negative impact on small enterprises, and large enterprises are more successful in the presence of autocratic and laissez-faire style; (ii) enterprises in the growth and maturity phase are more successful in knowledge management in the presence of laissez-faire style, while all three leader- 
TAB LE 9 Impact of Different Leadership Styles on the Aggregate Variable of Knowledge Management Success (\%)

\begin{tabular}{|c|c|c|c|c|c|c|c|}
\hline Variable & (1) & (2) & (3) & (4) & (5) & (6) & (7) \\
\hline $\mathrm{L} 1$ & & & 5 & & & & 1 \\
\hline L4 & -1 & & -1 & -1 & & & -5 \\
\hline L7 & & & & -1 & 10 & & \\
\hline L 10 & -1 & -1 & & & -10 & -1 & -1 \\
\hline L 13 & & & 1 & & 5 & & 5 \\
\hline $\mathrm{L} 16$ & & & & & & 5 & \\
\hline \multicolumn{8}{|l|}{$\mathrm{L} 2$} \\
\hline $\mathrm{L} 5$ & & 10 & 1 & & & & 1 \\
\hline L 8 & & & & -5 & & 1 & \\
\hline L 11 & -5 & & & & & & \\
\hline L 14 & & & & & & 1 & -1 \\
\hline $\mathrm{L} 17$ & & & -1 & -1 & 5 & & \\
\hline L3 & & & 1 & & 1 & & \\
\hline L6 & & & 10 & 5 & & & \\
\hline L9 & & & 5 & 10 & & 1 & \\
\hline L 12 & -5 & & -10 & -1 & & & \\
\hline L15 & & & & & 1 & 1 & \\
\hline $\mathrm{L} 18$ & 5 & & & 10 & & & \\
\hline Autocratic & - & - & + & - & + & $\oslash$ & $\oslash$ \\
\hline Democratic & - & + & $\oslash$ & - & + & + & $\oslash$ \\
\hline Laissez-faire & $\oslash$ & $\oslash$ & + & $\oslash$ & + & + & $\oslash$ \\
\hline
\end{tabular}

NOTES Column headings are as follows: (1) all together, (2) SME, (3) large, (4) growth and maturity phase (leaders), (5) stagnation phase (followers), (6) international, (7) domicile. The table shows the levels of significance and the direction of impact of independent variables.

ship styles have a positive impact on enterprises in the stagnation phase; (iii) enterprises oriented towards international markets are more successful in the presence of democratic style and laissez-faire, while enterprises oriented towards domicile markets are neutral with respect to the impact of leadership styles on the knowledge management success.

\section{References}

Bennis, W. 2007. 'The Challenges of Leadership in the Modern World: Introduction to the Special Issue.' American Psychologist 62 (1): 2. 
Blaschke, L. M. 2012. 'Heutagogy and Lifelong Learning: A Review of Heutagogical Practice and Self-Determined Learning.' The International Review of Research in Open and Distributed Learning 13 (1): 56-71.

Bouckenooghe, D., A. Zafar, and U. Raja. 2015. 'How Ethical Leadership Shapes Employees' Job Performance: The Mediating Roles of Goal Congruence and Psychological Capital.' Journal of Business Ethics 129 (2): 251-64.

Fragouli, E. 2016. 'Leadership Decision Making and Business Development: What Should be Considered Nowadays to Assist Business Development?' The Business \& Management Review 8 (2): 77-92.

Kaplan, R. S., and D. P. Norton. 2001. 'Transforming the Balanced Scorecard from Performance Measurement to Strategic Management: Part I.' Accounting Horizons 15 (1): 87-104.

Križmarić, Ž. 2014. 'Strateški menadžment u korelaciji s upravljanjem radnom uspješnošću i oblikovanjem poslova.' Tehnički glasnik 8 (1): 48-52.

Lew, Y. K., R. R. Sinkovics, and O. Kuivalainen. 2013. 'Upstream Internationalization Process: Roles of Social Capital in Creating Exploratory Capability and Market Performance.' International Business Review 22 (6): 1101-20.

Marr, B., and Neely, A. 2003. 'Automating the Balanced Scorecard-Selection Criteria to Identify Appropriate Software Applications.' Measuring Business Excellence 7 (3): 29-36.

Mehta, S. 2016. 'A Review Paper on Leadership Styles of Managers Among Public and Private Sector Banks and Its Relationship with Other Constructs.' International Journal of New Innovations in Engineering and Technology 4 (4): 107-15.

Moon, M. J. (2000). 'Organizational Commitment Revisited in New Public Management: Motivation, Organizational Culture, Sector, and Managerial Level.' Public Performance \& Management Review 24 (2): 17794.

Morgado, L., J. Varajão, C. Dominguez, I. Oliveira, and F. Sousa. 2014. 'Balancing European sme Managers' Training Contents.' Business Systems Research Journal 5 (2): 4-22.

Nahapiet, J., and S. Ghoshal. 1998. 'Social Capital, Intellectual Capital, and the Organizational Advantage.' Academy of Management Review 23 (2): 242-66.

Northouse, P. G. 2015. Leadership: Theory and Practice. Thousand Oaks, C A: Sage.

Osmanagić-Bedenik, N. 2015. 'The Challenge of Controlling.' International Journal of Industrial Engineering and Management 6 (4): 153-63.

Parmenter, D. 2015. Key Performance Indicators: Developing, Implementing, and Using Winning KPIs. Hoboken, NJ: Wiley. 
Pejic Bach, M. 2014. 'Exploring Information and Communications Technology Adoption in Enterprises and its Impact on Innovation Performance of European Countries.' Ekonomicky Casopis 62 (4): 335-62.

Rašič, K., M. Mulej, and V. Čančer. 2016. 'The Influential Knowledge Factors of Companies' Performance in Slovenia.' Business Systems Research Journal 7 (1): 46-58.

Renko, M., A. El Tarabishy, A. L. Carsrud, and M. Brännback. 2015. 'Understanding and Measuring Entrepreneurial Leadership Style.' Journal of Small Business Management 53 (1): 54-74.

Roblek, V., M. Pejić Bach, M. Meško, and A. Bertoncelj. 2013. 'The Impact of Social Media to Value Added in Knowledge-Based Industries.' Kybernetes 42 (4): 554-68.

Sherehiy, B., W. Karwowski, and J. K. Layer. 2007. 'A Review of Enterprise Agility: Concepts, Frameworks, and Attributes.' International Journal of Industrial Ergonomics 37 (5): 445-6o.

Spee, A. P., and P. Jarzabkowski. 2011. 'Strategic Planning as Communicative Process.' Organization Studies 32 (9): 1217-45.

Tanriverdi, H. 2005. 'Information Technology Relatedness, Knowledge Management Capability, and Performance of Multibusiness Firms.' MIS Quarterly 29 (2): 311-34.

Terzieva, M., and V. Morabito. 2016. 'Learning from Experience: The Project Team is the Key'. Business Systems Research Journal 7 (1): 1-15.

Varnali, K. 2011. 'Personality Traits and Consumer Behavior in the Mobile Context: A Critical Review and Research Agenda.' International Journal of E-Services and Mobile Applications 3 (4): 1-20.

Verhoef, P. C. 2003. 'Understanding the Effect of Customer Relationship Management Efforts on Customer Retention and Customer Share Development.' Journal of Marketing 67 (4): 30-45.

Von Krogh, G., I. Nonaka, and L. Rechsteiner. 2012. 'Leadership in Organizational Knowledge Creation: A Review and Framework.' Journal of Management Studies 49 (1): 240-77.

Vrtiprah, V., and J. Sladoljev. 2012. 'The Impact of Employee Satisfaction on the Quality of Products and Service in the Hotel Company. Ekonomska misao i praksa no. 1: 97-122.

Wiig, K. M. 1997. 'Knowledge Management: Where Did It Come from and Where Will It Go?' Expert Systems with Applications 13 (1): 1-14.

Ženko, Z., M. Mulej, and V. Potočan. 2017. 'Knowledge-cum-Values Management Belongs to the Way out from Global Crisis.' Business Systems Research Journal 8 (1): 113-23. 


\title{
Asymmetric Pass-through Effects from Monetary Policy to Housing Prices in South Africa
}

\author{
Andrew Phiri \\ Nelson Mandela University, South Africa \\ phiricandrew@gmail.com
}

Following the recent financial crisis, spurred by the crash of house prices in the Us, there has been a renewed interest by academics in examining the pass-through effects of monetary policy instrument to house price inflation. This study examines the asymmetric pass through effects from monetary policy to house price inflation for the case of South Africa. Our study uses a momentum threshold autoregressive model and a corresponding threshold error correction model (MTAR-TECM). The empirical results reveal a negative and significant pass through from interest rates to house price inflation, even though such pass-through effects are relatively weak. Overall, these findings undermine the ability of the South African Reserve Bank (sA RB) to control real house price inflation.

Key Words: asymmetric cointegration, monetary policy instrument, house price inflation, South Africa

JEL Classification: C22, C52, E31, E52.

https://doi.org/10.26493/1854-6935.16.123-140

\section{Introduction}

In the aftermath of the global financial crisis, which was triggered by an asset bubble burst in the us housing market, there has been a surge of interest concerning the pass-through effects of monetary policy to housing prices. Given that housing prices are relevant to wealth accumulation, labour mobility, consumption, macroeconomic volatility and overall financial market stability, it is indeed surprising that most Central Banks objective function encompasses inflation and output stabilization directives yet ignores movements in asset prices (Naraidoo and Kasai 2012). Mishkin (2007) identifies six transmission channels through which the effects of monetary policy can pass-through to housing prices. These are via (i) user costs, (ii) future expectations, (iii) housing supply, (iv) wealth effects, (v) credit-channel effects, and (vi) balance sheet effects. The first of the three channels are direct whereas the remainder are indirect channels. Therefore, given its relative importance, the link between monetary 
policy and house prices has recently been the subject of a much-heated debate amongst academics and financial policymakers alike. On the forefront of this debate, the role of housing prices in the transmission mechanism of monetary policy is argued to be crucial for the implementation of an efficient monetary policy and it is believed that Central Banks would be more successful in responding to asset prices such as housing prices in addition to deviations of inflation from it's predetermined target (Bjornland and Jacobsen 2010).

Much empirical research has been devoted towards examining the link between housing prices and monetary policy instruments. A vast majority of the literature exists for industrialized economies such as the us (Del Negro and Otrok 2007; Vargas-Silva 2008; Gupta and Kabundi 2010), the U K (Elbourne 2008), Australia (Wadud, Bashar, and Ahmed 2012; Costello, Fraser, and MacDonald 2015), China (Xu and Chen 2012) and Japan (Iwata 2007). Unfortunately very little empirical research has been conducted for developing countries and in particular for SubSaharan Africa (ssA) countries, of which the available literature is focused on the South African economy (Gupta and Kasai 2010), Gupta, Jurgilas, and Kabundi 2010). Notably, all of the aforementioned studies rely on linear econometric models and this may be oversimplifying the relationship given the complex interaction between monetary policy and housing prices. Of recent, there has been a methodological shift of focus towards the possibility of an asymmetric pass-through from monetary policy to other transmission mechanisms such as exchange rates (Sollis and Wohar 2006; Zhang 2014), market rates (Payne and Waters 2008; Wang and Thi 2010; Fadiran and Ezeoha 2012; Becker, Osborn, and Yildirim 2012; Jin et al. 2014; Matemilola, Bany-Ariffin, and Muhtar 2015), and expectations (Dimitris and Leon-Ledesma 2007; Phiri and Lusanga 2011; Guney, Telatar, and Hasanov 2015). Nevertheless, the literature on the asymmetric relationship between monetary policy and housing prices remains quite limited on the subject and may be narrowed down to the studies of Simo-Kengne et al. (2013) and Tsai (2013).

Our study aims to build upon the existing literature by examining asymmetric pass-through effects between monetary policies and housing prices in South Africa using the recently developed momentum threshold autoregressive (MTAR) model. The motivation behind the use of the MTAR lies in its ability to accommodate for the testing of unit roots within a time series, model asymmetric cointegration and error correction effects, between a pair of time series. The success of the MTAR model in 
modelling the pass-through effects of monetary policy to other transmission mechanisms has been documented in previous studies such as Payne and Waters (2008), Wang and Lee (2009), Becker, Osborn, and Yildirim (2012) and Matemilola, Bany-Ariffin, and Muhtar (2015). What is most notable about the MTAR model is that it allows for different responses in equilibrium correction behaviour depending on whether deviations are negative or positive. This is a particularly valuable attribute when examining monetary policy transmission mechanisms in the presence of possible market rigidities.

Henceforth, the rest of the paper is structured as follows. The next section provides an overview of monetary policy in South Africa whereas the third section gives an overview of the housing market in South Africa. In the fourth section, the data and the empirical model are introduced whilst the fifth section presents the empirical results of the study. The paper is then concluded in the sixth section.

\section{Monetary Policy Conduct in South Africa}

Over the last five decades or so, monetary policy conduct by the South African Reserve Bank (SARB) has been characterized by four major policy regimes. The first regime was the liquid asset ratio-based (LA RB) system and was in effect from 1965 up until 1980. Under this regime, direct quantitative controls on interest rates and credit extension were the Reserve Bank's main policy strategies and these were executed in the form of ceilings placed on bank credit extended to the private sector, controls on the deposit rate, controls on foreign exchange as well as controls on hire purchase and consumer credit (Mollentze 200o). Notably, under this regime, very little importance was attached to interest rate, as a policy instrument and the Reserve Bank's main form of monetary control were minimum 'liquid' asset requirements imposed on commercial banks (Aron and Meullbauer 200o).

However, in the midst of a falling Bretton-Woods exchange rate system as well as the oil price shocks of 1973-1974 and 1979-1980, the direct controls system brought about disintermediation in the monetary market and thus resulted in a failure of monetary authorities to effectively control the domestic demand for credit. Consequentially, the Reserve Bank began to engage in a systematic shift away from the previous 'Keynesian' perspective of conducting monetary policy to a more market related approach. In particular, this policy shift came about in response to the recommendations of the De Kock Commission in 1979 and constituted of 
the phasing off certain direct controls and instituting changes in asset reserve requirements.

The SARB's second regime of policy conduct was the Cash Reserves (CR) system, which was a replacement of the previous direct controls system. In further adhering to recommendations of the De Kock Commission report in 1986, the SARB decided to switch to a monetarist approach to policy conduct in which M3 money supply targets become the anchor of monetary policy in South Africa (Phiri 2016). The Reserve Bank's main policy instrument was its discount rate and was used to influence the cost of overnight collateralised lending and ultimately affect market interest rates (Aron and Meullbauer 2000). However, due to financial liberalization, a more open capital account as well as a deteriorated relationship between money supply, inflation and output growth, the money-targeting framework was deemed as an ineffective monetary policy mandate and, accordingly, the SAR B sought a more heterogeneous approach towards policy conduct. This involved replacing the accommodation system with the repo system in March 1998, which saw banks enter into repurchase agreements in respect of various securities sold by tender to the SARB on a daily or intra-day basis for the purpose of acquiring liquidity (Akinboade, Niedermeier; and Siebrits 2002). The 'repo system' was coupled with pre-announced money supply targets and informal inflation targets of core inflation and collectively this constituted of the third regime of policy practice by the Reserve Bank.

In February 2000, the then minister of Finance, Mr. Trevor Manuel, announced yet another shift in South Africa's monetary policy mandate, this time towards a formal inflation target framework. Domestic monetary authorities viewed this policy switch as necessary since the previous eclectic monetary framework created uncertainties and the Reserve Bank's decisions were seen to be in conflict with the stated guideline for growth in money supply and bank credit extension (Phiri 2012). Under the inflation-targeting regime, the SAR B has been granted at its disposal, the manipulation of the repo rate in order to maintain levels of inflation within a pre-determined set target. Initially, the SA R B had put into place targets of 3 to 6 percent, which were to be met in 2002. However, between 2004 and 2005 the target was momentarily changed to a range of between 3 and 5 percent but has since been re-specified back to its initial range of 3 to 6 percent. Overall, the ultimate objective of these inflation targets is to reduce the inflation bias of discretionary policy since increased credibility leads inflation anticipations to moderate more rapidly (Khamfula 2004). 
Moreover, the inflation targeting framework is built upon other foundational pillars such as transparency, independence and accountability and these are attributes of monetary policy which ensure a 'sounder' financial environment. Up-to-date the inflation target regime continues to be the basis for monetary policy conduct by the Reserve Bank.

\section{A BRIEF REVIEW OF THE INTEREST RATE: HOUSING}

\section{TRANSMISSION MECHANISM}

According to standard economic theory, the influence of interest rates on housing market can be attributed to the monetary transmission mechanism and can be most conveniently described as interest rates exerting either direct or indirect effects on house prices. Under these direct transmission channels, changes in interest rates directly affects cash flow or income, such that when interest rates rise, then so does the interest burden of any outstanding debt and the after-housing-cost disposable income falls (Elbourne 2008). The combination of these effects is reminiscent of the dynamics underlying the asset pricing theory, in which the value of a house depends on the service flow from owning the house (rent), the after-tax interest cost and expected economic appreciation after deducting physical depreciation (Williams 2011). Collectively, this direct channel of transmission from interest rates to housing prices is more formally labelled as the 'user cost of capital' channel. Mishkin (2011) further notes that changes in economic-agent expectations of monetary policy actions can also exert an influence on the user cost of capital and ultimately on the demand for houses. For instance, expectations of future interest rates hikes could lower expected real rate of appreciation of housing prices, thereby raising the current user cost of capital, which would result in a decline in the demand for houses and ultimately the prices of houses. Finally, interest rates can direct affect housing prices through 'housing supply' effects, since higher short-term interest rates increase the cost of financing house construction, which reduce the number of constructed houses.

On the other end of the spectrum, the indirect effects of interest rate transmission on housing prices can summarized via the wealth and credit effects. The wealth effects have their theoretical underpinnings in the life cycle hypothesis of Modigliani and Brumberg (1954) which assumes that an increase in all forms of wealth (inclusive of housing prices) should exert a positive effect on household consumption, an effect derived from a long-run marginal propensity to consume out of wealth that slightly ex- 
ceeds the real interest (Mishkin 2007). Simply put, the life cycle hypothesis assumes that an increase in real house prices is expected to exert longterm positive effects on non-housing consumption and negative income and substitution effects. Meanwhile the 'credit channel' of transmission is a result of the easing of credit constraints on household brought about by raising home equity which can provided additional means to finance higher consumer spending (Wadud, Bashar, and Ahmed 2012). In particular, the credit effect supposes that higher interest rates reduce housing wealth and household access to credit through lower collateral levels, which eventually leads to credit constrained households reducing their consumption spending in response to a fall in housing prices (Elbourne 2008).

\section{An Overview of South Africa's Housing Market}

South Africa is one of Africa's largest economies and is currently ranked in the top five of Africa's largest property market destinations. South Africa's domestic housing market is the largest component of the South African property market, consisting of a majority of property assets within the country, and is an important component of household wealth (Rust 2006). As of June 2015, the South African deeds register counted for 5.8 million registered residential properties whose total worth was approximately R 4.6 billion and ranges from sectional title and freehold properties, to estate; including government-sponsored homes, homes occupied by their owners or rented to others, and holiday homes. The residential housing market in South Africa is categorized into four pricing groups namely; properties below R300 ooo, properties between R300 000 and $\mathrm{R} 600$ ooo, properties between $\mathrm{R} 600$ ooo and R1.2 million as well as property over R1.2 million. Notably, about 45 percent of housing property in South Africa is listed under property valued below R300 ooo and this reflects the impact of the National Housing Subsidy Scheme which provides subsidized housing units to low income households. This has resulted in a shift in the composition of South Africa's property market, with the proportion of lower value housing properties increasing relative to the rest of the market (Rust 2006). Nevertheless, residential properties above the value of $\mathrm{R} 1.2$ million continues to account for more than 50 percent of the total value of the housing market in South Africa.

Historically, the South African residential property has been subject to wavering forms of growth patterns in response to exogenous events 
on the macroeconomy (Clark and Daniel 2006). In this regard, developments in the domestic housing market has been dominated by monetary policy actions and in particular by interest rate and exchange rate movements. During the 1980's, the economy had relatively high growth rates in housing prices and this was mainly due to negative interest rate policy and a strong domestic currency spurred by escalating gold prices (Clark and Daniel 2006). However, following the depreciation and subsequent crash of the Rand in the mid-1980's, the SAR в began to implement aggressive interest rate hikes that resulted in a sharp plunge in the growth of housing prices which fell to negative rates between 1985 and 1986. Afterwards, the real housing market in South Africa experienced a downward correction up until 1998 and this created a very low real house price base off which saw the housing market enter into one of its biggest price growth booms, which lasted, from 1999 to 2007.

There are two structural changes, which are responsible for the aggressive house price boom experienced between 1999 and 2007. Firstly, the political transition to a democratic state in 1994 brought about the abolishment of trade sanctions, increased financial liberalization, political stability and extensive trade reforms. This, in turn, contributed to the lowering of inflation levels to single digits at relatively low real rates of interest, which further resulted in improvements in investment, export growth, employment, economic growth and ultimately household income. Secondly, the South African Reserve Bank's (sarb) experienced a shift away from eclectic monetary supply targets towards a formal inflation-targeting regime. This caused in a downward structural adjustment of interest rates from the year 2000 onwards. Notably, the South African housing market reached a record high in over 30 years with an average house price growth of 32 percent in 2004. However, this was short lived as a major financial crisis hit the us property market in 2007, which saw the growth in domestic housing prices take yet another plunge in 2008 and eventually this growth turned negative in 2009 as the SARB implemented a series of aggressive interest rate manipulations in fear of further aggravating the already depressed economy. It was only after the 2008 financial crisis that the Reserve Bank began paying more attention to the volatility of exchange rates and placing emphasis on the role of asset prices as a means of ensuring stability in the South African financial markets (Phiri 2016). Since then, the growth in housing prices has slowly recuperated even though such growth is not nearly as high as that experienced in the mid-200o. 


\section{Methodology}

Engle and Granger (1987) developed a standard method for verifying cointegration between time series variables. According to the authors, cointegration within the system of equations exists when a pair of individual time series are first difference stationary and the cointegration residuals formed from their long-run equilibrium are levels stationary. This condition enables for the construction of a unique cointegration vector comprising of a linear combination of the time series. Thereafter, the residuals of the cointegration vector can be normalized for the time series through an error correction model (ECM) which measures the deviation of the series from its steady-state equilibrium. However, recent developments have suggested that the conventional linear cointegration framework is misspecified and therefore produces low testing power. One way of circumventing this issue, is to model the steady-state equilibrium residuals as a threshold autoregressive (TAR) process (Enders and Granger 1998). Enders and Silkos (2001) suggest that the steady-state errors $\left(\xi_{t}\right)$ can be modelled as the following variations of nonlinear cointegration regressions:

$$
\begin{aligned}
& \xi_{t}=\rho_{1} \xi_{t}\left(\xi_{t}<0\right)+\rho_{2} \xi_{t}\left(\xi_{t} \geq 0\right)+v_{t 1}, \\
& \xi_{t}=\rho_{1} \xi_{t}\left(\xi_{t}<\tau\right)+\rho_{2} \xi_{t}\left(\xi_{t} \geq \tau\right)+v_{t_{2}}, \\
& \xi_{t}=\rho_{1} \xi_{t}\left(\Delta \xi_{t}<0\right)+\rho_{2} \xi_{t}\left(\Delta \xi_{t} \geq 0\right)+v_{t_{3}}, \\
& \xi_{t}=\rho_{1} \xi_{t}\left(\Delta \xi_{t}<\tau\right)+\rho_{2} \xi_{t}\left(\Delta \xi_{t} \geq \tau\right)+v_{t_{4}},
\end{aligned}
$$

where $\rho_{1}$ is a measure of asymmetric adjustment when the equilibrium error is below its threshold and $\rho_{2}$ is a measure of asymmetric adjustment above its threshold level. Regressions (1) and (2) are known as the TAR model with a zero threshold (TAR(o)) and the TAR model with a consistent threshold estimate (TAR $(\tau)$ ), respectively. On the other hand, regressions (3) and (4) are known as the MTAR model with a zero threshold (MTAR(O)) and the MTAR model with a consistent threshold estimate $(\operatorname{MTAR}(\tau))$. As noted by Enders and Silkos (2001), M TAR adjustment can be especially useful when describing how policymakers smooth out any large changes in a financial series such as interest rates. On the other hand, TAR regression are designed to capture a series characterized by deep and sharp movements in residual behaviour. Enders and Granger (1998) propose a three-step procedure for testing and estimating the TAR and MTAR cointegration models. Firstly, the unknown threshold variable $(\tau)$ in equations (2) and (4) must be determined. Since these thresh- 
olds are unknown a prior, we use Hansen's (200o) method to estimate the unknown threshold. This involves ordering the threshold value in ascending order such that $\tau_{\mathrm{o}}<\tau_{1}<\cdots<\tau_{T}$, where $T$ is the number of observations after tranculating the lower and the upper 15 percent of the observations. Thereafter, a grid search is performed to estimate the true value of the threshold as the value, which minimize the residual sum of squares (Rss). Secondly, we must test for (i) normal cointegration effects (i.e. Hoo: $\rho_{1}=\rho_{2}=0$ ); and (ii) threshold cointegration effects (i.e. Hоo: $\left.\rho_{1} \neq \rho_{2}\right)$. Both tests are performed with a standard $F$-test statistics denoted as $\Phi$ and $\Phi^{\star}$, respectively. Thirdly, if null hypotheses testing no cointegration and no threshold cointegration can both be rejected, then the final estimates of the parameters $\rho_{1}$ and $\rho_{2}$ are obtained using the previously determined threshold.

\section{Data and Empirical Analysis}

\section{DATA AND UNIT ROOT TESTS}

The time series data used in our study consists of the average real house price growth $\left(\right.$ house $_{t}$ ) and government securities treasury bills (int $t_{t}$ ), which are used as proxies for house price inflation and monetary policy instrument, respectively. The average nominal house price growth data has been collected from the Amalgamated Bank of South Africa (A B SA) whereas the treasury bills series has been collected from SARB online database. All data has been collected on monthly basis from 1967:01 to 2015:12.

Before we can make any analytical use of the empirical data, it is important to test for unit roots in the time series. A classical method of testing for unit roots involves subjecting a univariate time series $\left(y_{t}\right)$ to the following Dickey-Fuller type regression:

$$
y_{t}=\phi y_{t}-1+\varepsilon_{t} \text {. }
$$

And thereafter testing the null hypothesis of a unit root as но: $\phi=1$. Enders and Granger (1998) modified this procedure by incorporating asymmetric behaviour in the unit root testing regression. This is important because recent literature has shown that linear unit root tests have low and are misspecified if the time series evolves as a nonlinear process. By defining $\Delta y_{t}=y_{t}-y_{t-1}$, the variations of the TAR and MTAR specifications (1) through (4), can be respecified and then applied to test for asymmetries and unit roots within the data. These asymmetric unit root testing regressions are given as: 
TA B LE 1 Enders and Granger (1998) Nonlinear Unit Root Tests

\begin{tabular}{llcr}
\hline Time series & Model & $\Phi$ & $\Phi^{*}$ \\
\hline int $_{t}$ & $\operatorname{TAR}(0)$ & $23.02(0.00)^{\star * *}$ & $0.06(0.80)$ \\
& $\operatorname{TAR}(\tau)$ & $23.02(0.00)^{\star * *}$ & $0.06(0.80)$ \\
& $\operatorname{MTAR}(0)$ & $23.63(0.00)^{\star * *}$ & $0.72(0.40)$ \\
& $\operatorname{MTAR}(\tau)$ & $23.63(0.00)^{\star * *}$ & $0.72(0.40)$ \\
\hline house $_{t}$ & $\operatorname{TAR}(0)$ & $18.52(0.00)^{\star * *}$ & $0.16(0.69)$ \\
& $\operatorname{TAR}(\tau)$ & $19.33(0.00)^{\star * *}$ & $1.05(0.31)$ \\
& $\operatorname{MTAR}(0)$ & $19.09(0.00)^{\star * *}$ & $0.01(0.95)$ \\
& $\operatorname{MTAR}(\tau)$ & $21.98(0.00)^{\star * *}$ & $2.10(0.08)^{*}$
\end{tabular}

NOtes Significance codes: ${ }^{* *}$, ${ }^{* *}$, and ${ }^{*}$ denote 1 percent, 5 percent, and 10 percent significance levels, respectively.

$$
\begin{aligned}
& \Delta y_{t}=\psi_{1} \varepsilon_{t}\left(\varepsilon_{t}<0\right)+\rho_{1} \varepsilon_{t}\left(\varepsilon_{t} \geq 0\right)+v_{t_{1}} \\
& \Delta y_{t}=\psi_{1} \varepsilon_{t}\left(\varepsilon_{t}<\tau\right)+\rho_{1} \varepsilon_{t}\left(\varepsilon_{t} \geq \tau\right)+v_{t_{2}} \\
& \Delta y_{t}=\psi_{1} \varepsilon_{t}\left(\Delta \varepsilon_{t}<0\right)+\rho_{1} \varepsilon_{t}\left(\Delta \varepsilon_{t} \geq 0\right)+v_{t_{3}} \\
& \Delta y_{t}=\psi_{1} \varepsilon_{t}\left(\Delta \varepsilon_{t}<\tau\right)+\rho_{1} \varepsilon_{t}\left(\Delta \varepsilon_{t} \geq \tau\right)+v_{t_{4}}
\end{aligned}
$$

Regressions (6) and ( 7$)$ are the TAR(o) and TAR $(\tau)$ versions, whereas (8) and (9) are the MtaR(o) and MtaR $(\tau)$ versions, respectively. Based on these regressions two hypotheses are tested for. Firstly, we use a standard $F$-test $(\Phi)$ to test the null hypothesis of no asymmetries in the time series process (i.e. HoO: $\psi_{1}=\phi_{2}$ ) against the alternative of asymmetries in the process (i.e. Ho1: $\psi_{1} \neq \psi_{2}$ ). Secondly, we use a modified $F$-test $\left(\Phi^{\star}\right)$ in testing for the null of a unit root (i.e. H1O: $\psi_{1}=\psi_{2}=$ o) against the alternative of a stationary time series (i.e. H11: $\psi_{1} \neq \psi_{2} \neq 0$ ). The aforementioned unit root testing procedures are performed on our empirical data with the lag length of the unit roots being determined by the AIC. The results of these tests are reported in table 1 .

From table 1, it can be observed that the null hypothesis of no asymmetries in both interest rates and house price inflation is rejected at all significance levels for estimated threshold models. However, when testing for unit roots, we find that our test statistics cannot reject the null hypothesis of a unit root process for both time series variables. An exception is warranted for house prince inflation, whereby we find that the $\Phi^{\star}$ statistic rejects the null hypothesis in favour of stationarity at a 10 percent level of significance. Thus, given the overriding evidence of nonlinearity and unit root behaviour within the times series, we conclude that both interest 
rates and house price inflation are nonlinear I(1) processes. Notably, Clark and Daniel (2006) and Matemilola, Bany-Ariffin, and Muhtar (2015) find similar findings of a unit root in house price inflation and interest rates for South African data. In light of this, we proceed to our cointegration analysis and error correction modelling of the variables.

\section{COINTEGRATION ANALYSIS AND ERROR CORRECTION} MODELLING

Having verified that both interest rates and growth in housing prices are asymmetric I(1) variables, we proceed to our cointegration analysis. Since theory depicts that interest rates are endogenously related to housing price inflation (Tsai 2013), our long run cointegration regression is specified as:

$$
\text { house }_{t}=\beta_{\mathrm{o}}+\beta_{1} \text { int }_{t}+\xi_{t},
$$

where house t $_{t}$ is the growth in housing prices, int $t_{t}$ is the interest rate variable and $\xi_{t}$ is the equilibrium error. We use Enders and Granger's (1998) three-step procedure for estimation of the cointegration models and record the empirical results in table 2. To recall, we first have to estimate the unknown threshold value for the $\operatorname{TAR}(\tau)$ and MTAR $(\tau)$ specifications. As reported in table 2, we obtain threshold estimate values of -6.76 and -0.81 for the TAR $(\tau)$ and $\operatorname{MTAR}(\tau)$ models, respectively. We then perform the tests for cointegration and threshold effects for the $\operatorname{TAR}(0), \operatorname{TAR}(\tau), \operatorname{MTAR}(0)$ and $\operatorname{TAR}(\tau)$ specifications using the $\Phi$ and $\Phi^{*}$ statistics. In testing the null hypotheses of no cointegration, we obtain $\Phi$ statistics of $24.76,25.79,25.52$ and 28.68 , respectively. Note that all of these statistics manage to reject the null hypothesis of no cointegration between interest rates and growth in housing prices at all significance levels thus implying cointegration amongst the time series. However, the $\Phi^{*}$ statistics obtained in testing for threshold cointegration effects are less optimistic, with only the test statistics from the $\operatorname{MTAR}(\tau)$ specification managing to reject the null hypothesis of no threshold cointegration effects at a 5 percent level of significance. This find is in alignment with Tsai (2013) who also finds that asymmetric pass-through effects between interest rates and house price inflation is best capture as a MTAR process. Given our evidence of the MTAR $(\tau)$ model being the best mode for capturing asymmetric cointegration among the variables, we therefore estimate this model for the time series using standard oLs method. As is reported in table 2 , we obtain a significant slope coefficient estimate $\left(\beta_{1}\right)$ of 
TABLE 2 Threshold Cointegration Estimates

\begin{tabular}{lcccc}
\hline Model type & TAR $(0)$ & $\mathrm{TAR}(\tau)$ & $\operatorname{MTAR}(0)$ & $\operatorname{MTAR}(\tau)$ \\
\hline$\tau$ & 0 & -6.761 & 0 & -0.811 \\
$\Phi$ & $24.76(0.00)^{* * *}$ & $25.79(0.00)^{* * *}$ & $25.52(0.00)^{* * *}$ & $28.68(0.00)^{* * *}$ \\
$\Phi^{*}$ & $0.05(0.82)$ & $1.03(0.32)$ & $0.80(0.38)$ & $3.77(0.05)^{*}$ \\
$\beta_{0}$ & & & $11.23(0.00)^{* * *}$ \\
$\beta_{1}$ & & & $-0.02(0.04)^{*}$ \\
$\rho_{1} \xi_{t-1}$ & & & $-0.38(0.02)^{*}$ \\
$\rho_{2} \xi_{t-1}$ & & & $-0.58(0.01)^{* *}$ \\
\hline$R^{2}$ & & & 0.57 \\
\hline
\end{tabular}

NOTES Significance codes: ${ }^{* \star},{ }^{* *}$, and ${ }^{\star}$ denote 1 percent, 5 percent, and 10 percent significance levels, respectively. $t$-statistics are reported in parentheses.

-0.02, which indicates a low degree of pass-through effects amongst the time series. We are particularly encouraged by this result since it adheres to conventional monetary theory, which postulates a negative relationship between interest rates and housing prices. Also estimates of -0.38 and -0.58 are obtained for the equilibrium threshold error terms $\rho_{1}$ and $\rho_{2}$, respectively. Note that this implies that positive deviations from the steady state are eliminated at a quicker rate than that of negative deviations which is an indication of downward rigidity of house price inflation equilibrium adjustments. Similarly, Gao, Lin, and $\mathrm{Na}$ (2009) also find that a monetary policy shock induced to house price appreciation during declining periods will have less 'momentum' to be transferred to the later periods.

In view of the verifying asymmetric cointegration existing between interest rates and housing price inflation in South Africa, we proceed to introduce an associated threshold error correction model (TECM) for our estimated $\operatorname{MTAR}(\tau)$ specification. The resulting $\operatorname{MTAR}(\tau)$-TEC model is specified as follows:

$$
\begin{aligned}
\Delta \text { house }_{t}= & \alpha_{\mathrm{O} 1}+\sum_{i=1}^{n} \phi_{i 1} \Delta \text { house }_{t-i}+\sum_{i=1}^{n} \delta_{i 1} \Delta \text { int }_{t-i} \\
& +\gamma_{11} \xi_{t-1}\left(\Delta \xi_{t}<\tau\right)+\gamma_{21} \xi_{t-1}\left(\Delta \xi_{t} \geq \tau\right)+\mu_{t 1} \\
\Delta \text { int }_{t}= & \alpha_{\mathrm{O} 2}+\sum_{i=1}^{n} \phi_{i 2} \Delta \text { house }_{t-i}+\sum_{i=1}^{n} \delta_{i 2} \Delta \text { int }_{t-i} \\
& +\gamma_{12} \xi_{t-1}\left(\Delta \xi_{t}<\tau\right)+\gamma_{22} \xi_{t-1}\left(\Delta \xi_{t} \geq \tau\right)+\mu_{t 2} .
\end{aligned}
$$


TABLE $3 \quad \operatorname{MTAR}(\tau)$-TEC model estimates

\begin{tabular}{|c|c|c|}
\hline Item & 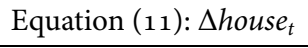 & Equation (12): $\Delta i n t_{t-i}$ \\
\hline$\gamma_{1 i}$ & $-0.37(0.54)$ & $-2.73(0.00)^{\star * *}$ \\
\hline$\gamma_{21}$ & $-0.15(0.68)$ & $-0.13(0.79)$ \\
\hline H3O: $\gamma_{=} \gamma_{2}$ & $0.10(0.75)$ & $9.77(0.00)^{* * *}$ \\
\hline H4O: $\phi_{i}=\mathrm{o}$ & $1.89(0.16)$ & $0.08(0.92)$ \\
\hline $\mathrm{H} 50: \gamma_{i}=\mathrm{O}$ & $1.75(0.19)$ & $12.85(0.00)^{* * *}$ \\
\hline$R^{2}$ & 0.020 & 0.650 \\
\hline DW & 1.856 & 1.865 \\
\hline $\mathrm{LB}(4)$ & 0.270 & 0.010 \\
\hline
\end{tabular}

Notes Significance codes: ${ }^{* *},{ }^{\star *}$, and ${ }^{\star}$ denote 1 percent, 5 percent, and 10 percent significance levels, respectively. $t$-statistics are reported in parentheses.

Based on these threshold error correction (TEC) regressions (11) and (12), two main sets of hypothesis are tested for. Firstly, the null hypothesis of no asymmetric error correction model (i.e. H3O: $\gamma_{1}=\gamma_{2}$ ) can be tested against the alternative of an otherwise threshold error correction model. Secondly, we test for the direction of causality amongst the time series. The null hypothesis that house ${ }_{t}$ does not granger cause int $t_{t}$ is tested as H 40: $\phi_{i}=\mathrm{o}$ whereas the null hypothesis that $i_{t} t_{t}$ does not granger cause house $_{t}$ is tested as H5O: $\gamma_{i}=0$. The empirical results for the estimated $\operatorname{MTAR}(\tau)$-TEC model are provided in table 3 .

As can be observed in table 3 , the null hypothesis of no threshold error correction effects can only be rejected for the housing equation (11). Furthermore, the speed of adjustment is found to be significant for the $\Delta i n t_{t}$ equation in the lower regime $\left(\gamma_{1 i}\right)$ but not for the $\Delta$ house $_{t}$ equation in both upper and lower regimes. This suggests that house price inflation is weakly exogenous in equilibrium correcting behaviour. Notably, this result is in coherence with that obtained in Gupta and Kasai (2011) who find that house price inflation is a weakly exogenous variable for South African data. Moreover, the causality tests performed on the time series further verify this assumption of a weakly exogenous house price inflation. As can be further observed in the lower panel of table 3, the null hypothesis of int $t$ not leading house $e_{t}$ is rejected at a 1 percent significance level whereas the null of house $e_{t}$ not leading int $t_{t}$ cannot be rejected at all. This result concurs with finance theory which suggest that interest rates are endogenous whilst house price inflation is weakly exogenous. However, our earlier empirical results have also shown that the pass-through 
effect from monetary policy instrument to house price inflation in South Africa is rather weak. Collectively, these results undermines the Reserve Bank's ability to control real house price inflation, which is most likely being explained by itself (Gupta and Kasai 2011). We further allude these findings of a low response coefficient between interest rates and housing inflation, to the special government-housing subsidy to low income households, which resulted in lower housing properties increasing their position in the composition of South Africa,s housing market.

\section{Conclusions}

Of recent, it has been argued that the pass through effects from monetary policy instruments to house price inflation would best be captured as a nonlinear relationship (Tsai 2013). In this paper, we sought to examine asymmetric pass through effects from prime interest rates to house price inflation in South Africa, hence adding to the limited available literature on the subject matter for Sub-Saharan African (ssA) economies. Our choice of empirical model is the moment regressive model coupled with a corresponding threshold vector error model (MTAR-TECM). The empirical results reveal a negative and significant relationship between the prime interest rates and real house price inflation even though the degree of pass-through is found to be quite low. In particular, our empirical result indicate the an interest rate change of 1 percent will results in an opposite movement of house price inflation of 0.02 percent. Furthermore, our findings reveal downward rigidity in the equilibrium adjustment of house price inflation, which is most like a result of the downward correction that the South African housing market has been experiencing over the couple of years. In this regard, our results show that disequilibrium caused by positive shock to house price inflation, as induced by a decrease in interest rates, would revert to equilibrium at a faster rate than for the case of a negative shock to house prices as induced by an interest rate hike.

Our overall empirical analysis bears a number of important policy implications for the South African economy. For one, our study implies that whilst there are significant asymmetric pass-through effects from monetary policy instrument to real house price inflation, these pass-through effects are quite small. This, in turn, undermines the Reserve Bank's ability to effectively influence house price inflation through the sole manipulation of interest rates. Given the recent us hikes in the fed rates, the SA RB will most likely react by hiking future domestic interest rates. How- 
ever, due to the low pass through effects, this increase in domestic interest rates will have very little effect on house price inflation. Another implication, which can be drawn from our study, is that monetary policy should consider the low asymmetric pass-through effects to house price inflation in the design of their policies. This is important because current monetary policy conduct will not be able to stabilize house price inflation in the event of a housing market bubble or a market crash. Therefore, as a proposition, future research can focus on identifying other intermediate channels through which the effects of monetary policy asymmetrically influence house price inflation. Future research could also expand the available literature towards other ss a countries such Nigeria, Angola, Mozambique and Kenya whose residential property markets are quite developed.

\section{References}

Akinboade, O., E. Niedermeier, and F. Siebrits. 2002. 'The Dynamics of Inflation in South Africa.' South African Journal of Economics 70 (3): 213-23.

Aron, J., and J. Meullbauer. 200o. 'Estimating Monetary Policy Rules for South Africa.' Central Bank of Chile Working Paper 89, Central Bank of Chile, Santiago de Chile.

Becker, R., D. Osborn, and D. Yildirim. 2012. 'A Threshold Cointegration Analysis of Interest Rate Pass-through to U K Mortgage Rates.' Economic Modelling 29:2504-13.

Bjornland, H., and D. Jacobsen. 2010, 'The Role of House Prices in the Monetary Policy Transmission Mechanism in Small Open Economies.' Journal of Financial Stability 6:218-29.

Clark, A., and T. Daniel. 2006. 'Forecasting South African House Prices'. Investment Analysts Journal 64:27-34.

Costello, G., P. Fraser, and G. MacDonald. 2015. 'Monetary Influences in Australian Housing Markets.' International Journal of Housing Market and Analysis 8 (2): 265-86.

Del Negro, M., and C. Otrok. 2010. '99 Luftballons: Monetary Policy and the House Price Boom Across us States.' Journal of Monetary Economics 54 (7): 1962-85.

Dimitris, K., and M. Leon-Ledesma. 2007. 'A Long-Run Non-Linear Approach to the Fischer Effect.' Journal of Money, Credit and Banking 39 $(2-3): 543-59$.

Elbourne, A. 2008. 'The uk Housing Market and the Monetary Policy Transmission Mechanism: An SVAR Approach.' Journal of Housing Economics 17 (1): 65-87. 
Enders, W., and C. Granger. 1998. 'Unit Roots and asymmetric Adjustment with an Example Using the Term Structure of Interest Rates.' Journal of Business and Economic Statistics 16:304-11.

Enders, W., and P. Silkos. 2001. 'Cointegration and Threshold Adjustment.' Journal of Business and Economic Statistics 19 (2): 166-76.

Engle, C., and K. Granger. 1987. 'Co-Integration and Error Correction: Representation, Estimation and Testing'. Econometrica 55 (2): 251-76.

Fadiran, G., and A. Ezeoha. 2012. 'South African Market Volatility, Asymmetry and Retail Interest Rates Pass-through.' South African Journal of Economics 80 (2): 157-80.

Gao, A., Z. Lin, and C. Na. 2009. 'Housing Market Dynamics: Evidence of Mean Reversion and Downward Rigidity'. Journal of Housing Economics 18 (3): 256-66.

Guney, P., E. Telatar, and M. Hasanov. 2015. 'Time Series Behaviour of the Real Interest Rate in Transition Economies.' Economic Research 28 (1): 104-18.

Gupta, R., M. Jurgilas, and A. Kabundi. 2010. 'The Effect of Monetary Policy on Real House Price Growth in South Africa: A Factor-Augmented Vector Autoregression (FAVA R) Approach.' Economic Modelling 27 (1): 315-23.

Gupta, R., and A. Kabundi. 2010. 'The Effect of Monetary Policy on House Price Inflation: A Factor Augmented Vector Autoregression (FAVAR) Approach.' Journal of Economic Studies 37 (6): 616-26.

Gupta, R., and N. Kasai. 2011. 'Financial Liberalization and the Effectiveness of Monetary Policy on House Prices in South Africa.' The IUP Journal of Monetary Economics 8 (4): 59-74.

Hansen, B. 2000. 'Sample Splitting and Threshold Estimation.' Econometrica 68 (3): 575-603.

Iwata, K. 2007. 'Housing and Monetary Policy in Japan.' Proceedings - Economic Policy Symposium - Jackson Hole, 445-61. Kansas City, Mo: Federal Reserve Bank of Kansas City.

Jin, X., F. Song, Y. Wang, and Y. Zhong. 2014. 'Interest Rate Pass-Through in a Dual-Track System.' China and the World Economy 22 (4): 21-39.

Khamfula, Y. 2004. 'Macroeconomic Policies, Shocks and Economic Growth in South Africa.' https://www.imf.org/external/np/res/seminars/ 2005/macro/pdf/khamfu.pdf

Matemilola, B., A. Bany-Ariffin, and F. Muhtar. 2015. 'The Impact of Monetary Policy on Bank Lending Rate in South Africa.' Borsa Istanbul Review 15 (1): 53-9.

Mishkin, F. 2007. 'Housing and the Monetary Transmission Mechanism.' Working Paper 13518, National Bureau of Economic Research, Cambridge, MA. 
Modigliani, F., and R. Brumberg. 1954. 'Utility Analysis and Aggregate Consumption Function: An Attempt at Integration.' In Post-Keynesian Economics, edited by K. Kurihara, 388-436. New Brunswick, NJ: Rutgers University Press.

Mollentze, S. 2000. 'Monetary Policy in South Africa on the Threshold of a New Era.' South African Journal of Economic and Management Sciences ss (2): 1-50.

Naraidoo, R., and N. Kasai. 2012. 'Financial Asset Prices, Linear and Nonlinear Policy Rules: An in-Sample Assessment of the Reaction Function of the South African Reserve Bank.' Journal of Economic Studies 39 (2): 161-77.

Payne, J., and G. Waters. 2008. 'Interest Rate Pass Through and Asymmetric Adjustment: Evidence from the Federal Funds Rate Operating Target Period.' Applied Economics 40 (11): 1355-62.

Phiri, A. 2012. 'Threshold Effects and Inflation Persistence in South Africa.' Journal of Financial Economic Policy 4 (3): 247-69.

- 2016. 'Examining Asymmetric Effects in the South African Phillips Curve: Evidence from Logistic Smooth Transition Regression Models.' International Journal of Sustainable Economy 8 (1): 18-42.

Phiri, A., and P. Lusanga. 2011. 'Can Asymmetries Account for the Empirical Failure of the Fisher Effect in South Africa?' Economics Bulletin 31 (3): 1968-79.

Rust, K. 2006. 'Analysis of South Africa's Housing Sector Performance.' https://housingfinanceafrica.org/app/uploads/

HSectorPerformanceDec.pdf

SimoKengne, B., M. Balcilar, R. Gupta, M. Reid, and G. Aye. 2013. 'Is the Relationship between Monetary Policy and Housing Prices Asymmetric Across Bull and Bears Markets in South Africa? Evidence from a Markov-Switching Vector Autoregressive Model.' Economic Modelling 32 (c): 161-71.

Sollis, R., and M. Wohar. 2006. 'The Real Exchange Rate-Real Interest Rate Relation: Evidence from Tests for Symmetric and Asymmetric Threshold Cointegration.' International Journal of Finance and Economics 11 (2): 139-53.

Tsai, I. 2013. 'The Asymmetric Impacts of Monetary Policy on Housing Prices: A Viewpoint of Housing Price Rigidity.' Economic Modelling 31:405-13.

Vargas-Silva, C. 2008. 'Monetary Policy and the us Housing Market: A VAR Analysis Imposing Sign Restrictions.' Journal of Macroeconomics 30 (3): 977-90.

Wadud, M., O. Bashar, and H. Ahmed. 2012. 'Monetary Policy and the Housing Market in Australia.' Journal of Policy Modeling 34 (6): 849-63. 
Wang, K., and Y. Lee. 2009. 'Market Volatility and Retail Interest Rate PassThrough.' Economic Modeling 26:1270-82.

Wang, K., and T. Thi. 2010. 'Asymmetric Pass-Through and Risk of Interest Rate: An Empirical Explanation of Taiwan and Hong Kong.' Applied Economics 42:659-70.

Williams, J. 2011. 'Monetary Policy and Housing Booms.' International Journal of Central Banking 7 (1): 345-55.

$\mathrm{Xu}, \mathrm{X}$., and T. Chen. 2012. 'The Effect of Monetary Policy on Real Estate Price Growth in China,' Pacific-Basin Finance Journal 20 (1): 62-77.

Zhang, G. 2014. 'Exchange Rates and Monetary Fundamentals: What Do We Learn from Linear and Nonlinear Regressions?' Economics Research International. http://dx.doi.org/10.1155/2014/746956

This paper is published under the terms of the Attribution-

NonCommercial-NoDerivatives 4.o International (CC BY-NC-ND 4.0)

License (http://creativecommons.org/licenses/by-nc-nd/4.o/). 


\title{
Time-Frequency Analysis of CAPM: Application to the CAC 40
}

\author{
Roman Mestre \\ University of Montpellier, France \\ roman.mestre@live.fr \\ Michel Terraza \\ University of Montpellier, France \\ m.terraza@orange.fr
}

The market line estimation implicitly assumes that its parameters are constant over time supposing whatever the investment horizon, the investors have a similar behaviour. In this paper, we discuss this hypothesis using the technique of wavelets. First, we verify the expected result concerning the statistical weaknesses of market line and the high volatility of its parameters. Second, we use the wavelets to estimate the frequency betas. We show that the classic beta (estimated with ols) considers a short-run beta. We propose a methodology based on time-frequency analysis that leads to an overview of equities characteristics useful to portfolio managers.

Key Words: market line, wavelets, MODW T, frequency betas

JEL Classification: Goo, G11, G12

https://doi.org/10.26493/1854-6935.16.141-157

\section{Introduction}

Modern portfolio theory is initiated by Markowitz (1952) and it is extended with the Capital Asset Pricing Model (CA P M) by Sharpe (1964), Lintner (1965), and Mossin (1966). The main idea is the systematic risk of an asset related to its link with the market (the system). The СА PM implies that the market is the only risk factor explaining stock prices. The sensibility of the security to the market is measured by the beta (systematic risk). The model was tested in many econometrics studies as Black, Jensen, and Scholes (1972), Fama and MacBeth (1973). These studies highlight the instability of СА Р M parameters (including the beta) according to the chosen period or the data frequency. But the validity or the rejection of the CAPM can't be totally proved. The CA PM's validity (or rejection) is always discussed because the beta is widely used by investors as a risk indicator. 
The hypothesis of constant beta is one of the biggest CAPM criticisms because it supposes agents have a similar behaviour. They select their assets homogeneously but nothing certifies a similar investment horizon. Some agents are high frequency traders (as banks) using automatic algorithms, whereas mutual funds have a longer investment. So, if we suppose that they invest in the same assets (but with different horizons), in this case they don't face necessarily the same risk level.

According to the frequency, the risk could be different and linked with a time horizon. The investor has a different behaviour so the systematic risk level has differentiated values and dynamics across frequency. This topic is the main subject of Gençay, Selçuk, and Whitcher (2005). They prove the existence of systematic risk at frequency level by using wavelets but they don't study Beta temporal evolution. They also indicate the pertinence of CA P M's relationships at medium and long run.

For testing the Heterogeneous Behaviour hypothesis, we use the frequency decomposition of stock prices enhanced by a temporal location. This is the Maximal Overlap Discret Wavelets Transform or Modw T (Mallat 1989; 2001; 2009; Meyer 1990). We are able to study the behaviour of the chronic by frequency levels while having a temporal location by frequency bands. This process is perfectly appropriate to our problem.

In the case, we use the CAPM of the 30 permanent stocks quoted on the French market CAC 40 for the daily period from January 2005 to December 2015. This period includes calm and turbulent market's periods as the 'subprime' crisis. In a first part, we present the CAPM and we estimate the market's line parameters in order to verify their instability over time. In a second part, we use the wavelets to construct a time-frequency CA PM considering the heterogeneous behaviour of agents. We show that for a portfolio manager, the investment choices are more differentiated by using frequency betas.

\section{Theoretical and Empirical CAPM}

\section{CAPM'S LITERATURE OVERVIEW}

The Capital Asset Pricing Model of Sharpe (1964) is based on the Securities Market Line equation (or SML)

$$
R_{i, t}=r f+\beta_{i}\left(R_{m, t}-r f\right) .
$$

The CAPM explains the return of an asset $i, R_{i, t}$, by the market returns $R_{m, t)}$. In portfolio theory, the agents invest in equities (risky assets) and in a risk-free asset with return noted $r f$. Consequently, the equities have 
to offer bigger returns than risk-free asset. This is the risk premium noted $r_{i, t}$. From equation (1), we define the Market Premium $r_{m, t}$ as the difference of Market return and risk-free rate. We can write equation (1) with risk premia such as:

$$
r_{i, t}=\alpha_{i}+\beta_{i} r_{m, t}+\varepsilon_{i, t} .
$$

The parameters of equation (2) are estimated by oLs, $\varepsilon_{i, t}$ are residuals of the regression supposed to be a white noise process i.i.d $\left(\mathrm{o}, \sigma_{\varepsilon}\right)$. The slope of this line represents the Systematic risk. By construction it is constant over time. Theoretically, $\alpha_{i}$ is null, it represents the shift between the forecasted value of the expected return and empirical excepted return. This parameter is useful to test the validity of the model.

Concerning the CAPM's literature, many studies focuses on it validity. The first studies, realized in the late 1960s, tend to confirm the model. But the works of Sharpe and Cooper (1972) focus on several statistical biases related to estimation methods. These results are confirmed by others authors such as Black, Jensen, and Scholes (1972), Fama and MacBeth (1973) in US A's stocks markets. However, these authors highlight the instability of parameters (mainly the beta) according to the chosen period and frequency's data. In the European stock markets, these conclusions are similar (Modigliani, Pogue, and Solnik 1972).

In 1992, the biggest criticism of the model is formulated by Fama and French. For these authors the 'beta is dead' because many stylized facts are not considered by the CAPM. Multifactor model was developed such as Arbitrage Pricing Theory or Fama-French Model. In the opposite side, Chan and Lakonishock (1993) consider the Beta is not totally dead because there are not pertinent and sufficient arguments 'to kill' it. So, the CA PM validity or rejection is not totally established and the Beta is widely used.

Many papers focus on the Beta instability phenomenon because it is the major parameter of the CA P M. The studies of Fabozzi and Francis (1978), Bos and Newbold (1984) confirm the Beta instability over time. The beta volatility ascends with the length of the period, because in the returns's structures the ols method doesn't consider breaks. Since these works, Groenwold and Fraser (1997) revisit the model with different methods to correct the beta. One of these methods estimates the Beta for 5 years period introducing the principle of Rolling Beta Estimate with varying window size. Hawawini (1983) studies the impact of data frequency on the Beta value and gives an adjusted measure to correct the beta. This one 
is different in the case of daily, weekly or monthly data and it depends on the bias based on the asset's market value.

The beta is related to the horizon and the frequency of the data which is inadequate with the hypothesis of homogeneous behaviour of agents. In practice, agents have different investment horizons so, the beta's estimations must consider these facts. Following this hypothesis, Gençay, Selçuk, and Whitcher (2005) analyse the beta by a wavelets approach with daily data. They conclude that the CA PM is more relevant in medium and long run.

In this paper, we follow the work of Gençay, Selçuk, and Whitcher (2005) in order to appreciate the impact of behavioural hypothesis on the systematic risk in French Stock-Market. We use the log-excess returns of 30 listed companies and the CAC4O index (as the proxy of Market) for the daily period from January 2005 to December 2015. The rate of 'OAT 10 years' is the risk-free rate. In order to catch different investment horizon with the wavelets frequency bands, we use daily data from Yahoo Finance database and Banque de France (French Central Bank) website.

CLASSIC BETA ESTIMATE (PERIOD 2005-2015)

The betas are estimated over the period, then we repeat this procedure over sub-periods. And finally, we study the volatility and instability of betas using rolling regression. In the paper, the Beta estimated by oLs is called the 'Classic Beta' opposite to the 'Frequency Betas' estimated by Wavelets.

Before estimation, we test the stationary character of the variables with the Philips-Perron test (and KPss). Residuals of the oLs estimation are autocorrelated, heteroscedastic and non-Gaussian. The minimum variance property is not respected. The regression is repeated using QuasiGeneralized Least Squares (GLS) with the Newey-West matrix (1987) more robust to unknown forms of autocorrelation and heteroscedasticity.

Table 1 summarizes the results of GLS estimations and provides the Rsquared and usual tests on parameters and residuals. We accept the significance of Betas and $R^{2}$, but the residuals are autocorrelated and heteroscedastic with a strong non-normality for the majority of equities. Despite these weaknesses, using betas, it is possible to differentiate and characterize easily stocks. For example, financial stocks have a high beta compared to the communication sector stocks like Vivendi and Publicis. It is therefore possible, to classify equities by the beta, its characteristics and its temporal evolution. If the Beta is greater than 1, the equity am- 


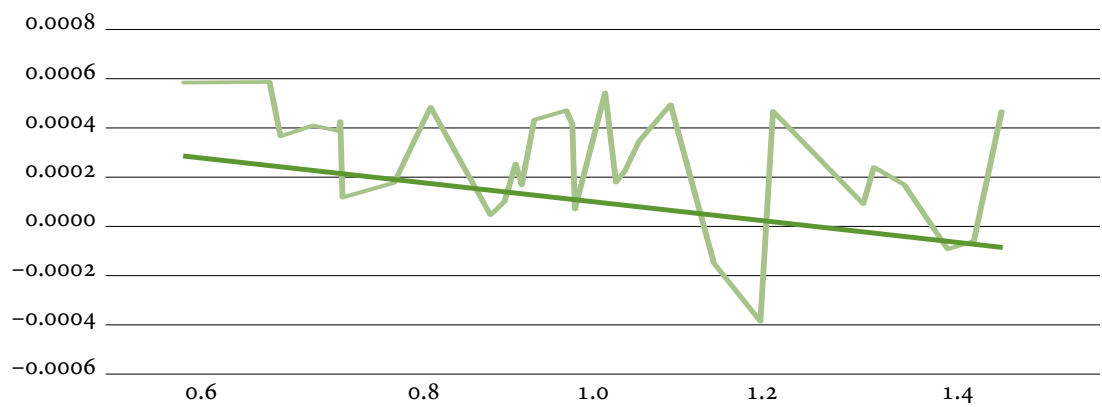

FIGURE 1 Return-Beta Relation

plifies the markets movements. If it is lesser than 11 , the stock attenuates the market fluctuations. The value of the beta is important for a portfolio manager to appreciate the systematic risk. According to the CAPM theory, a stock with a high beta (high systematic risk) must have consequently a higher expected return than a stock with low beta. Figure 1 represents in the ordinate the mean return of the asset versus the Betas in the abscissa.

\section{ANALYSIS OF CLASSIC BETA INSTABILITY}

By analysing the result of figure 1, we note that the equities with high beta have a lower risk premium compared to low beta stocks. These results imply a decreasing SML contrary to the CAPM hypothesis. The time period includes many shocks such as the financial crisis (2008), the debt crisis (2011-2012) and may cause this result. So, our original sample is divided into three, in order to consider different periods: the first one stretches from January 2005 to December 2007 corresponding to a 'calm' period where the market is expanding. The second one begins from January 2008 to December 2012 including the 'subprime' crisis and the European debt crisis. The last period covers a period of economic recovery is from 2013 to 2015.

Moreover, the ad hoc hypothesis of parameters stability implies that the Betas are similar overtime. To confirm or reject this hypothesis, we use forwards rolling regressions with a window of 260 days ( 1 year in business trading days). As example, figure 2 illustrates the betas estimated by rolling year for AXA. By comparing the classic constant beta of table 1 , we can visualize the instability phenomenon of the beta, and this situation persists for all stocks.

We can make equities classification according to characteristics of their 
TABLE 1 GLS estimates

\begin{tabular}{|c|c|c|c|c|c|c|c|c|}
\hline (1) & (2) & (3) & (4) & (5) & (6) & (7) & $(8)$ & (9) \\
\hline Accor & 0.99 & 24.85 & 0.000403 & 1.73 & 0.47 & 13.56 & 16.49 & 5812.89 \\
\hline Airbus & 0.95 & 30.9 & 0.000363 & 1.11 & 0.35 & 13.81 & 0.83 & 106016 \\
\hline Alcatel & 1.22 & 36.93 & -0.000446 & -0.95 & 0.32 & 1.34 & 34.01 & 14326.7 \\
\hline Air Liquide & 0.83 & 29.81 & 0.000409 & 2.9 & 0.65 & 13.11 & 57.43 & 6729.28 \\
\hline $\mathrm{AXA}$ & 1.51 & 31.74 & 0.000425 & 1.81 & 0.68 & 21.07 & 62.13 & 41993.2 \\
\hline BNP & 1.39 & $13 \cdot 38$ & 0.00012 & 0.46 & 0.61 & 29.64 & 311.01 & 36979.6 \\
\hline Bouygues & 1.06 & 34.65 & 0.000157 & 0.63 & 0.51 & 0.3 & 57.04 & 1774.4 \\
\hline $\mathrm{CA}$ & 1.44 & 21.91 & -0.000141 & -0.47 & 0.56 & $13 \cdot 97$ & 161.13 & 7641.56 \\
\hline Carrefour & 0.9 & 26.56 & $-3 \cdot 39 e^{-5}$ & -0.14 & 0.48 & 2.83 & 76.2 & 3926.46 \\
\hline Danone & 0.65 & 31.47 & 0.000277 & 1.64 & 0.41 & 9.19 & 231.21 & 4778.36 \\
\hline Essilor & 0.54 & 13.16 & 0.000501 & 2.64 & 0.31 & 11.92 & 105.44 & 16498.4 \\
\hline GDF & 0.94 & 21.81 & $9.33 e^{-5}$ & 0.47 & 0.5 & 30.29 & 20.3 & 164186 \\
\hline Gemini & 1.04 & 41.79 & 0.000476 & 1.86 & 0.48 & 10.45 & 14.25 & 2722.26 \\
\hline St-Gobain & 1.34 & 29.81 & $3.65 e^{-5}$ & 0.18 & 0.67 & 12.37 & 222.05 & 15224.2 \\
\hline L’Oréal & 0.72 & 22.52 & 0.000346 & 2.03 & 0.48 & 26.83 & 40.74 & 4951.32 \\
\hline LVMH & 1 & 36.81 & $3 \cdot 48 e^{-4}$ & 1.91 & 0.62 & 13.24 & 38.34 & 10867.6 \\
\hline Michelin & 1.08 & 24.89 & 0.000281 & 1.29 & 0.49 & 13.96 & 29.17 & 3655.4 \\
\hline Orange & 0.73 & 18.83 & $3.50 e^{-5}$ & 0.16 & 0.43 & 17.7 & 37.81 & 4480.43 \\
\hline PSA & 1.17 & 27.4 & -0.000211 & -0.53 & 0.39 & 7.69 & 116.57 & 1614.53 \\
\hline Publicis & 0.72 & 43.9 & 0.000306 & 1.52 & 0.43 & 28.88 & 70.5 & 1972.62 \\
\hline Renault & 1.36 & 30.46 & 0.00019 & 0.55 & 0.55 & 12.36 & 122 & 2371.17 \\
\hline Ricard & 0.69 & 14.87 & 0.000327 & 1.77 & 0.36 & 31.55 & 143.78 & 8181.13 \\
\hline Schneider & 1.24 & 52.97 & 0.000412 & 2.13 & 0.68 & 25.79 & 41.25 & 976.5 \\
\hline Sodexo & 0.64 & 16.67 & 0.000502 & 2.6 & 0.36 & 10.21 & 21.25 & 9219.78 \\
\hline SG & 1.47 & 16.48 & -0.000106 & -0.39 & 0.56 & 65.51 & 304.57 & 13567.8 \\
\hline Technip & 1.05 & 27.25 & 0.000113 & 0.35 & 0.39 & 17.01 & 30.72 & 6149.54 \\
\hline Total & 0.93 & 20.68 & 0.000183 & 1.19 & 0.67 & 11.82 & 155.56 & 2095.14 \\
\hline Veolia & 0.92 & 24.27 & $2.78 e^{-5}$ & 0.09 & 0.39 & 8.31 & 1.58 & 160406 \\
\hline Vinci & 1.11 & 27.05 & 0.000434 & 2.62 & 0.67 & 5.19 & 208.29 & 5024.85 \\
\hline vivendi & 0.79 & 47.02 & $9.86 e^{-5}$ & 0.52 & 0.52 & 4.9 & 16.85 & 7732.78 \\
\hline
\end{tabular}

Notes Column headings are as follows: (1) GLS, (2) beta, (3) $t$-statistics, (4) constant, (5) $t$ statistics, (6) $R^{2}$, (7) Ljung-Box test, (8) ARCH-LM test, (9) Jarque-Bera test. At $5 \%$ level of risk, column $(7): \chi^{2}(5)=11.1$, column $(8): \chi^{2}(2)=5.99$, colum $(9): \chi^{2}(2)=5.99$. At $5 \%$ risk level, Fisher statistic is 3.85 and all $R^{2}$ are significantly different from zero.

betas volatility. With the Rolling Betas we can improve more precisely the systematic risk measure. With the following considerations we can characterise the volatility's degree of the Beta (table 2). 


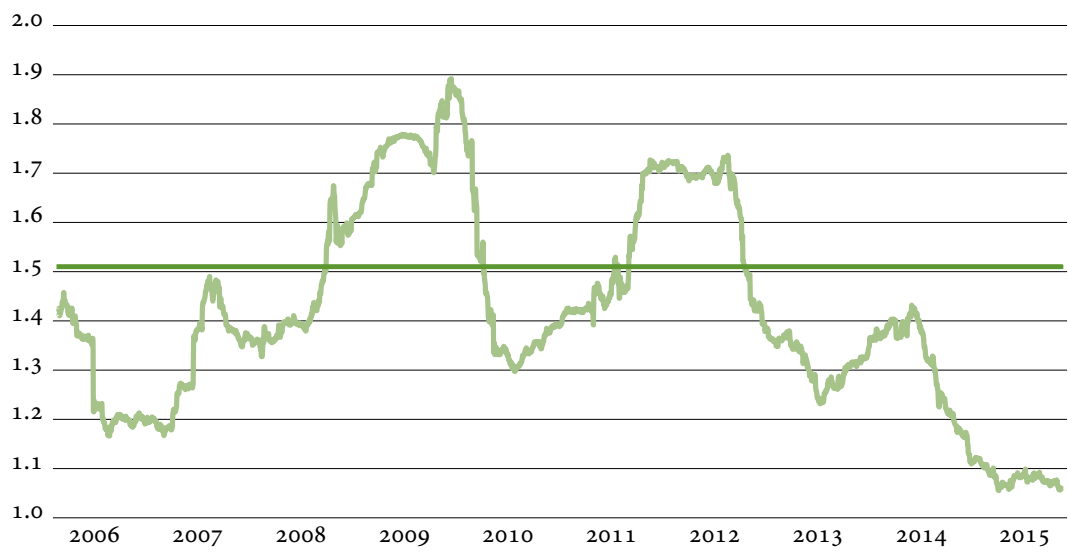

FIGURE 2 Rolling Betas of AXA (light - rolling Betas, dark - classic Beta)

- The estimated betas are tested (equality to 1 ) and classified by their standard deviation. We create three groups classified by their degree of volatility (the first three columns of the table).

- To select the betas equal to 1 , the $t$-statistics is sometimes insufficient because the betas fluctuate around 1 without stabilizing. We count in the following 3 columns, the percentages of beta higher, lower or equal than 1.

- In the last three columns, we put down the percentages of beta inside or outside the confidence interval of the beta estimated by oLs for characterizing the volatility of betas.

First, we note that the number (and the nature) of equities in each category is different according to the period. It supports the hypothesis of market's line instability over time. For the first period, we notice a fair repartition of equities in each class and there is consequently a fair diversity of profiles. However in crisis time, there are few equities with betas equal to 1 and more stocks with high betas. Furthermore, Betas are more volatile during the crisis which ensues a pronounced non-robustness and a lower percentage of betas inside the confidence interval. A stock is considered robust if the majority of its rolling betas are in the same category of the classic beta.

It is also possible to create syntheses by economic sector: the financial sector has mostly betas greater than 1 but volatile (such as automotive sector). In the other side, the media-advertising industry has mainly betas lesser than 1 with a low volatility. With these tables it is possible to 
TABLE 2 Volatility of Beta for the Overall Period

\begin{tabular}{|c|c|c|c|c|c|c|c|c|c|c|}
\hline Groups & Stocks & (1) & (2) & (3) & (4) & (5) & (6) & (7) & (8) & (9) \\
\hline \multirow[t]{14}{*}{ (a) } & Publicis & 0.72 & -17.93 & 0.07 & 100.00 & 0.00 & 0.00 & 51.89 & 23.66 & 24.45 \\
\hline & GDF & 0.94 & -3.57 & 0.09 & 58.80 & 40.94 & 0.27 & 44.04 & 25.03 & 30.93 \\
\hline & Vivendi & 0.79 & -15.26 & 0.11 & 93.18 & 3.11 & 3.72 & 35.19 & 16.72 & 48.10 \\
\hline & Air Liquide & 0.83 & -14.93 & 0.11 & 83.40 & 16.60 & 0.00 & 34.65 & 8.78 & 56.57 \\
\hline & Ricard & 0.69 & -17.89 & 0.11 & 100.00 & 0.00 & 0.00 & 76.73 & 7.75 & 15.52 \\
\hline & L'Oréal & 0.72 & -19.97 & 0.12 & 97.82 & 2.19 & 0.00 & 41.24 & 12.77 & 45.99 \\
\hline & Danone & 0.65 & -23.84 & 0.12 & 99.62 & 0.38 & 0.00 & 30.85 & 49.06 & 46.99 \\
\hline & Total & 0.93 & -5.77 & 0.13 & 60.98 & 24.49 & 14.53 & 49.41 & 12.50 & 38.10 \\
\hline & Sodexo & 0.64 & -22.65 & 0.16 & 97.39 & 2.11 & 0.50 & 60.60 & 8.36 & 31.04 \\
\hline & Airbus & 0.95 & -2.00 & 0.17 & 47.79 & 20.55 & 31.66 & 40.20 & 19.02 & 40.78 \\
\hline & Veolia & 0.92 & -3.90 & 0.20 & 80.38 & 2.77 & 16.86 & 68.69 & 11.89 & 19.43 \\
\hline & Essilor & 0.54 & -31.03 & 0.21 & 93.48 & 6.52 & 0.00 & 40.05 & 6.21 & 53.74 \\
\hline & Carrefour & 0.90 & -5.75 & 0.21 & 56.42 & 13.91 & 29.67 & 53.35 & 2.61 & 44.04 \\
\hline & Orange & 0.73 & -17.60 & 0.21 & 70.83 & 12.46 & 16.71 & 36.22 & 11.81 & 51.97 \\
\hline \multirow[t]{3}{*}{ (b) } & LVMH & 1.00 & -0.21 & 0.11 & 27.75 & 51.78 & 20.47 & 36.41 & 29.32 & 34.27 \\
\hline & Gemini & 1.04 & 1.80 & 0.19 & 36.60 & 18.86 & 44.54 & 45.61 & 10.62 & 43.77 \\
\hline & Accor & 0.99 & -0.52 & 0.21 & 59.41 & 8.93 & 31.66 & 40.20 & 19.02 & 40.78 \\
\hline \multirow[t]{13}{*}{ (c) } & Schneider & 1.24 & 14.72 & 0.14 & 4.40 & 8.06 & 87.54 & 41.81 & 20.05 & 38.14 \\
\hline & Bouygues & 1.06 & 3.02 & 0.14 & 32.00 & 20.09 & 47.91 & $43 \cdot 30$ & 20.98 & 35.72 \\
\hline & PSA & 1.17 & 6.04 & 0.15 & 12.46 & 12.11 & 75.43 & 39.06 & 26.44 & 34.50 \\
\hline & Vinci & 1.11 & 7.85 & 0.16 & 19.66 & 19.86 & 60.48 & 50.94 & 18.21 & 30.85 \\
\hline & Renault & 1.36 & 15.48 & 0.17 & 0.00 & 4.22 & 95.78 & 55.62 & 17.56 & 26.83 \\
\hline & Alcatel & 1.22 & 6.66 & 0.17 & 8.43 & 17.79 & 73.78 & 41.17 & 23.80 & 35.03 \\
\hline & Michelin & 1.08 & 3.70 & 0.17 & 24.65 & 30.29 & 45.07 & 51.28 & 18.33 & 30.39 \\
\hline & St-Gobain & 1.34 & 19.45 & 0.18 & 3.68 & 11.27 & 85.05 & 42.81 & 39.56 & 17.63 \\
\hline & $\mathrm{AXA}$ & 1.51 & 26.20 & 0.21 & 0.00 & 0.00 & 100.00 & 69.49 & 4.14 & 26.37 \\
\hline & BNP & 1.39 & 18.84 & 0.21 & 0.00 & 0.00 & 100.00 & 53.00 & 15.65 & 31.35 \\
\hline & Technip & 1.05 & 1.99 & 0.22 & 35.42 & 21.51 & 43.08 & 44.57 & 21.55 & 33.88 \\
\hline & $\mathrm{CA}$ & 1.44 & 18.46 & 0.23 & 0.81 & 2.04 & 97.16 & 49.37 & 29.43 & 29.44 \\
\hline & SG & 1.47 & 19.28 & 0.30 & 0.00 & 0.00 & 100.00 & 52.08 & 6.60 & 41.32 \\
\hline
\end{tabular}

Notes Colum/row headings are as follows: (1) classic beta, (2) $t$-statistics to $1,(3)$ standard deviation of beta, (4) percentage of beta $<1$, (5) percentage of beta $=1$, (6) percentage of beta $>1$, (7) percentage of lower CI, (8) percentage in CI, (9) percentage of upper CI, (a) betas always less than 1 , (b) betas always greater than $1,(\mathrm{c})$ volatile betas relative to 1.

construct a stock overview useful for a portfolio manager. We improve its investment opportunities by adding a frequency approach.

Table 3 illustrates our conclusions about the betas volatility for 3 equi- 
TABLE 3 Synthesis of the Betas Volatility

\begin{tabular}{lrrrr}
\hline Degree of Volatility & Overall Period & Period 1 & Period 2 & Period 3 \\
\hline LVMH & Medium & High & Low & High \\
AXA & High & Medium & High & High \\
Essilor & High & Low & Medium & Medium \\
\hline
\end{tabular}

ties (we built tables for all stocks): AXA with a high beta, LVMH with a beta equal to 1 and Essilor with a low beta.

\section{A Time-Frequency CA PM: A Wavelets Approach}

Wavelets are an extension of the spectral analysis of Fourier. We can evaluate the temporal evolution of the spectral values for different frequencies. A mother wavelet $\Psi$, in $L^{2}$ space, with null and standardized mean is defined by the following equation (we use Mallat's (2001) notation):

$$
\int_{-\infty}^{+\infty} \Psi(t) d t=0
$$

We define the wavelet family which regrouping all translated (by a parameter $\tau$ ) and dilated (by a scale parameter $s$ ) versions of the mother wavelet:

$$
\Psi_{\tau, s}(t) \frac{1}{\sqrt{s}} \Psi\left(\frac{t-\tau}{s}\right)
$$

The continuous wavelet transform of a temporal function $x(t)$ (realization of a random function of the same name) by a wavelet $\Psi(t)$ of scale $s$ and position $\tau$, gives the following convolution:

$$
W_{x}(\tau, s)=\frac{1}{\sqrt{s}} \int_{-\infty}^{+\infty} x(t) \Psi^{\star}\left(\frac{t-\tau}{s}\right) d t,
$$

$\Psi^{\star}$ is complex conjugate of $\Psi(t)$.

We can rebuild the original chronic with the wavelets coefficients $W_{x}(\tau, s)$. This is the inverse wavelet transform:

$$
x(t)=\frac{1}{C_{\Psi}} \int_{-\infty}^{+\infty} \Psi_{\tau, s}(t) W_{x}(\tau, d) \frac{d \tau d s}{s^{2}} .
$$

With $C_{\Psi}=\int_{0}^{+\infty} \frac{|\widehat{\Psi(\omega)}|^{2}}{\omega}$ the condition of existence of the wavelet, $\omega$ is the angular frequency and $\widehat{\Psi(\omega)}$ the Fourrier's transform of the imaginary part of $W_{x}(\tau, s)$.

In this paper, we use a discrete version of the wavelets transform called the Maximal Overlap Discrete Wavelets Transform (MODWT). The dis- 
TABLE 4 Frequency Bands and Their Corresponding Days and Months

\begin{tabular}{lrrrrr}
\hline \multirow{2}{*}{ Frequency bands } & \multicolumn{2}{c}{ Frequency days } & & \multicolumn{2}{c}{ Frequency months } \\
\cline { 2 - 3 } \cline { 5 - 6 } & Lower limits & Upper limits & & Lower limits & Upper limits \\
\hline D1 & 2 & 4 & 0.09 & 0.18 \\
D2 & 4 & 8 & 0.18 & 0.36 \\
D3 & 8 & 16 & 0.36 & 0.73 \\
D4 & 16 & 32 & 0.73 & 1.45 \\
D5 & 32 & 64 & 1.45 & 2.91 \\
D6 & 64 & 128 & 2.91 & 5.82 \\
D7 & 128 & 256 & 5.82 & 11.64 \\
D8 & 256 & 512 & 11.64 & 23.27 \\
D9 & 512 & 1024 & 23.27 & 46.55 \\
D10 & 1024 & 2048 & 46.55 & 93.09 \\
D11 & 2048 & 4096 & 93.09 & 186.18 \\
S11 & 4096 & - & 186.18 & - \\
\hline
\end{tabular}

cretization is useful to reduce the calculation time. It provides additive wavelet decomposition described by the following equation:

$$
X_{t}=A_{J, t}+\sum_{i=1}^{i=J} D_{i, t} .
$$

where $x_{t}$ is our starting signal (time series) constituted by an approximation of the trend noted $A_{J, t}$ and a sum of subseries $D_{i, t}($ for $i=1 \ldots J)$. These subseries are additional details added to the basic approximation; they are assimilating to the accuracy of the decomposition and the index $J$ corresponds to the optimal number of details. It is calculated as

$$
J=\frac{\operatorname{Ln}(n)}{\operatorname{Ln}(2)}
$$

where $n$ is the number of observations.

We are able to study the behaviour of the signal by frequency levels linked with time localization. Table 4 regroups the number of frequency bands and the corresponding days and months. We note that more the time scale increases more the band's variance is lower than high frequency bands.

\section{FREQUENCY BETA ESTIMATE}

The estimation of the frequency market's line beta parameter is performed on the bands D1 to D 6 corresponding to trading behaviours 
from 2 days to 6 months. All betas are significant but we note the use of wavelet does not resolve the heteroscedasticity and autocorrelation of the residuals. In contrast, the non-normality is reduced at low frequencies for few actions. Their $R^{2} \mathrm{~s}$ are different according to the stock. In general, they are high (around o.6-0.7) for strong betas stocks. We can't present all the results because of the large number (table 5 illustrates the frequency betas for the 30 equities).

According to the investment horizon the Betas are different. We distinguish equities with a classic beta less than 1 (respectively greater than 1 ) and all their frequency betas are in the same category. We show that there are stocks with volatile frequency betas compared to 1 and regrouped in the third category. There are also more stocks with all frequency betas less than 1 and their standard deviations are lower than high betas equities.

In order to appreciate the effect of the economic environment on Systematic Risk, we reiterate the wavelet methodology on the 3 previous subperiods. We add that differences between the frequency betas and the classic beta are more significant during the 'crisis' period. The frequency betas could appreciate more accurately the systematic risk during this period. Moreover, the frequency long-run betas are totally different of the classic beta, proving the importance of using wavelets to measure systematic risk for a long-term investment.

We compare the Frequency Betas with the Classic Beta by a Principal Component Analysis. By placing the classic beta as supplementary variable, its projection on the factorial axes is merged with high frequencies betas especially with D1 and D2 (figure 3). So, when managers use the market's line to manage their portfolios (the classic beta), they implicitly have a short-term trading behaviour. The PCA clearly reflects the diversity of choices that can be made according to the investment horizon. The projection of stocks on this factorial component clarifies the classification realized in table 5. Axis 1 (91.27\% of the total variance) opposes stocks with a beta greater than 1 for all wavelets scales (as Société Générale) to low beta stocks (beta less than 1) in most frequency bands (as Essilor). Axis 2 (5.57\% of the total variance) distinguishes stocks according to their frequency dynamics.

Another method to compare the frequency betas with classic betas is a significance test on the difference between these two Betas. Table 6 summarizes percentages of significant different betas for the three subperiods and the total period.

For D1 and D2 bands, differences are not significant for the majority of 
TABLE 5 Frequency Betas for the Global Period

\begin{tabular}{|c|c|c|c|c|c|c|c|c|c|}
\hline Groups & Stocks & D 1 & D2 & D3 & D4 & D 5 & D6 & (1) & (2) \\
\hline \multirow[t]{10}{*}{ (a) } & Carrefour & 0.9 & 0.92 & 0.85 & 0.95 & 0.88 & 0.75 & 0.07 & $0.9(<1)$ \\
\hline & Danone & 0.68 & 0.67 & 0.57 & 0.46 & 0.6 & 0.73 & 0.10 & $0.65(<1)$ \\
\hline & Essilor & 0.55 & 0.5 & 0.45 & 0.6 & 0.72 & 0.48 & 0.10 & $0.54(<1)$ \\
\hline & GDF & 0.93 & 0.98 & 0.87 & 0.95 & 0.96 & 0.8 & 0.07 & $0.94(<1)$ \\
\hline & L'Oréal & 0.76 & 0.73 & 0.61 & 0.55 & 0.7 & 0.81 & 0.10 & $0.72(<1)$ \\
\hline & Orange & 0.75 & 0.73 & 0.68 & 0.64 & 0.63 & 0.59 & 0.06 & $0.72(<1)$ \\
\hline & Publicis & 0.69 & 0.73 & 0.76 & 0.83 & 0.82 & 0.86 & 0.07 & $0.72(<1)$ \\
\hline & Ricard & 0.66 & 0.71 & 0.73 & 0.69 & 0.8 & 0.99 & 0.12 & $0.69(<1)$ \\
\hline & Sodexo & 0.61 & 0.69 & 0.66 & 0.65 & 0.65 & 0.61 & 0.03 & $0.64(<1)$ \\
\hline & Vivendi & 0.8 & 0.79 & 0.76 & 0.73 & 0.72 & 0.75 & 0.03 & $0.79(<1)$ \\
\hline \multirow[t]{8}{*}{ (b) } & Alcatel & 1.11 & 1.24 & 1.41 & 1.34 & 1.66 & 1.75 & 0.25 & $1.22(>1)$ \\
\hline & Axa & 1.45 & 1.56 & 1.54 & 1.61 & 1.52 & 1.77 & 0.11 & $1.51(>1)$ \\
\hline & BNP & 1.37 & 1.37 & 1.49 & 1.6 & 1.05 & 1.07 & 0.22 & $1.39(<1)$ \\
\hline & $\mathrm{CA}$ & 1.37 & 1.47 & 1.59 & 1.7 & 1.29 & 1.52 & 0.15 & $1.44(>1)$ \\
\hline & Renault & 1.22 & 1.39 & 1.56 & 1.62 & 1.47 & 2.01 & 0.27 & $1.35(>1)$ \\
\hline & Schneider & 1.25 & 1.24 & 1.18 & 1.24 & 1.15 & 1.08 & 0.07 & $1.24(>1)$ \\
\hline & SG & 1.38 & 1.45 & 1.7 & 1.71 & 1.54 & 1.91 & 0.20 & $1.47(>1)$ \\
\hline & St-Gobain & 1.31 & 1.35 & 1.35 & 1.5 & 1.44 & 1.49 & 0.08 & $1.34(>1)$ \\
\hline \multirow[t]{12}{*}{ (c) } & Airbus & 0.93 & 0.94 & 1.05 & 0.97 & 1.16 & 1.19 & 0.11 & $0.95(<1)$ \\
\hline & Gemini & 0.98 & 1.08 & 1.1 & 1.07 & 1.23 & 1.18 & 0.09 & $1.04(=1)$ \\
\hline & LVMH & 0.98 & 1.02 & 1.04 & 1 & 1.05 & 0.97 & 0.03 & $1(=1)$ \\
\hline & Accor & 0.91 & 1.06 & 1.11 & 1.07 & 1.05 & 1.18 & 0.09 & $0.99(=1)$ \\
\hline & Michelin & 1.01 & 1.11 & 1.23 & 1.12 & 1.06 & 1.16 & 0.08 & $1.08(>1)$ \\
\hline & PSA & 1.04 & 1.24 & 1.4 & 1.36 & 1.39 & 1.08 & 0.16 & $1.17(>1)$ \\
\hline & Technip & 0.99 & 1.06 & 1.2 & 1.16 & 1 & 1.05 & 0.09 & $1.05(>1)$ \\
\hline & Total & 0.94 & 0.94 & 0.87 & 0.95 & 0.99 & 0.83 & 0.06 & $0.93(<1)$ \\
\hline & Veolia & 0.86 & 0.86 & 1.06 & 1.11 & 1.17 & 1.34 & 0.19 & $0.92(<1)$ \\
\hline & Vinci & 1.12 & 1.14 & 1.12 & 1.04 & 0.91 & 1.04 & 0.09 & $1.11(>1)$ \\
\hline & Bouygues & 1.06 & 1.04 & 1.08 & 1.11 & 1 & 1.11 & 0.04 & $1.06(>1)$ \\
\hline & Air liquide & 0.87 & 0.81 & 0.78 & 0.78 & 0.83 & 0.6 & 0.09 & $0.83(<1)$ \\
\hline
\end{tabular}

NOTES Column/row headings are as follows: (1) betas SD (standard deviation of frequency betas of the corresponding stock), (2) classic beta, (a) betas always less than 1, (b) betas always greater than $1,(c)$ volatile betas relative to 1 . Because of large numbers of Betas we don't present the results for the 3 sub-periods.

stocks at short-term horizons. The low frequency bands have 60 to $80 \%$ of the frequency beta significantly different of classic betas. This result confirms our previous hypothesis, the use of classic betas supposes the 
FIGURE 3

Correlation Circle with the Classic Betas in Supplementary Variable (G)

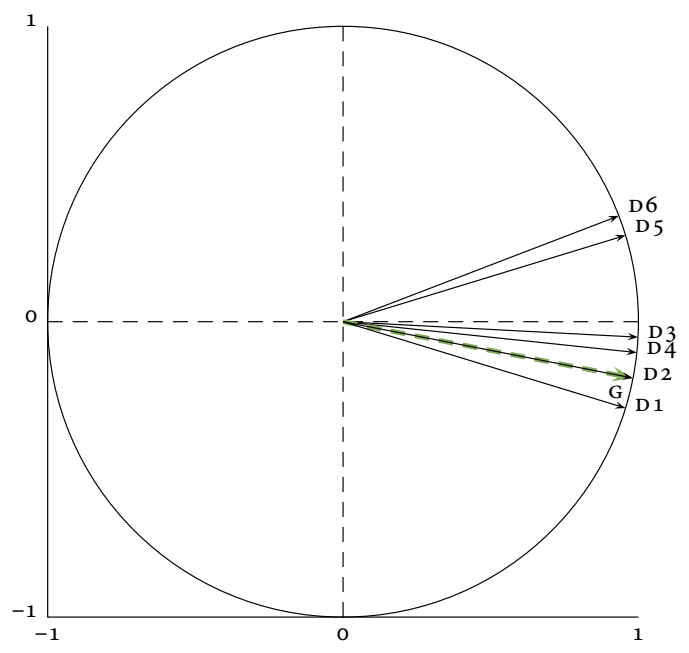

TA B LE 6 Percentages of Significantly Different Betas

\begin{tabular}{lrrrrrr}
\hline Period & D 1 & D 2 & D3 & D4 & D5 & D6 \\
\hline Period 1 & 0.00 & 3.33 & 16.67 & 33.33 & 60.00 & 73.33 \\
Period 2 & 16.67 & 10.00 & 60.00 & 70.00 & 53.33 & 80.00 \\
Period 3 & 6.67 & 6.67 & 40.00 & 46.67 & 56.67 & 63.33 \\
Overall Period & 30.00 & 10.00 & 66.67 & 60.00 & 63.33 & 80.00 \\
\hline
\end{tabular}

systematic risk over short horizons. It is strongly dependent of the chosen frequency (the investment horizons). Stocks are differentially sensitive to the market and investors should include the temporal volatility in their procedure but also the frequency volatility of systematic risk.

\section{ANALYSIS OF THE FREQUENCY BETA INSTABILITY}

We study the volatility of frequency betas using rolling regressions with a 26o-days window. Given the large number of stocks and frequency bands, we retain only D1 bands (for short horizons) and D6 (for long investment) of the previous selected equities. Table 7 records results for the frequency betas using the same methodology presented in the section on classic beta estimate.

These results extended to all stock can be synthesized by an investor based on their own preferences and criteria which they consider more relevant. For example, high volatility is considered by a standard deviation of rolling betas greater than 0.15 and low volatility by standard devi- 
TABLE 7 Frequency Betas Volatility

\begin{tabular}{lrrrrrrrrrr}
\hline$(1)$ & $(2)$ & $(3)$ & $(4)$ & $(5)$ & $(6)$ & $(7)$ & $(8)$ & $(9)$ & $(10)$ & $(11)$ \\
\hline LVMH D1 & 0.98 & -1.62 & 0.1 & 37.03 & 41.78 & 21.2 & 0.00 & 36.41 & 29.32 & 34.27 \\
Axa D 1 & 1.45 & 24.44 & 0.18 & 0.00 & 0.00 & 100.00 & 0.00 & 65.93 & 7.36 & 26.72 \\
Essilor D 1 & 0.55 & -29.72 & 0.23 & 88.54 & 10.58 & 0.88 & 0.00 & 40.02 & 3.91 & 56.08 \\
\hline LVMH D6 & 0.97 & -2.60 & 0.38 & 45.34 & 7.67 & 46.99 & 0.00 & 36.41 & 29.32 & 34.27 \\
Axa D6 & 1.77 & 36.99 & 0.59 & 16.86 & 3.87 & 79.26 & 0.00 & 70.37 & 2.61 & 27.02 \\
Essilor D6 & 0.48 & -34.06 & 0.43 & 88.62 & 3.60 & 7.78 & 15.44 & 60.83 & 4.60 & 34.57 \\
\hline LVMH & 1 & -0.21 & 0.11 & 27.75 & 51.78 & 20.47 & 0.00 & 36.41 & 29.32 & 34.27 \\
AXA & 1.51 & 26.20 & 0.21 & 0.00 & 0.00 & 100 & 0.00 & 69.49 & 4.14 & 26.37 \\
Essilor & 0.54 & -31.03 & 0.21 & 93.48 & 6.52 & 0.00 & 0.00 & 40.05 & 6.21 & 53.74 \\
\hline
\end{tabular}

Notes Colum headings are as follows: (1) overall period, (2) frequency betas, (3) $t$-statistics 1 , (4) standard deviation of beta, (5) percentage of beta $<1,(6)$ percentage of beta $=1$, (7) percentage of beta $>1$, (8) percentage of beta $\leq 1$, (9) percentage of lower CI, (10) percentage in CI, (11) percentage of upper $\mathrm{CI}$.

TABLE 8 Syntheses of Frequency Betas Volatility

\begin{tabular}{lllll}
\hline Period & & Classic Beta & Beta D 1 & Beta D6 \\
\hline Overall Period & LVMH & Medium & Medium & High \\
& AXA & High & High & High \\
& Essilor & High & High & High \\
\hline Period 1 & LVMH & High & High & High \\
& AXA & Medium & Low & High \\
& Essilor & Low & High & High \\
\hline Period 2 & LVMH & Low & Low & High \\
& AXA & High & Medium & High \\
& Essilor & Medium & Medium & High \\
\hline Period 3 & LVMH & High & Medium & Medium \\
& AXA & High & Medium & High \\
& Essilor & Medium & Medium & High \\
\hline
\end{tabular}

ation less than 0.1. By analysing the characteristics of betas values, we can create a summary described in table 8 .

The beta volatility is more important for the total period than the three sub-periods. Betas for medium frequency D 6 are more volatile than the short-term betas (D1). We can make an equities overview based on the time-frequency characteristics useful for appreciate the Systematic Risk related to our investment horizon. 


\section{Conclusion and Discussion}

The market's line estimation on the period 2005-2015 presents statistical anomalies cause of the autocorrelation and the heteroscedasticity in residuals. The volatility of beta, illustrated by rolling regressions, is probably the most important reason of the residual nature.

Due to the characteristics of frequency betas volatility, we realize an equity's classification useful to appreciate the systematic risk adding the heterogeneity hypothesis of agents. It is studied by time-frequency estimation of the market's line over the period and sub-periods. There is a differentiation of betas according to the frequency and the selected period. If the manager uses the classic beta to measure his systematic risk, he makes 'mistakes' omitting the impact of the investment horizon on the risk.

To illustrate this conclusion, Veolia stock on the period 2005-2015 has a beta equal to 0.92 . This stock attenuates the market fluctuations by losses (or earnings) which are lower than the market. The risks profile is more defensive-tracker useful in crisis. It is established without taking into consideration the different investment horizons. To estimate the frequency betas by using the wavelets, we note that the short-run beta is 0.86 (investment horizon of 2 to 4 days so it is the D1 bands) while the long-run beta (for an investment horizon of 3 to 6 months) is 1.34. If the portfolio manager uses the classic beta of this stock for investing in short-term, he minimizes his defensive performance. However, if he invests in longrun he has a beta greater than one and therefore the stock became more aggressive.

The distinction by frequency betas multiplies the investment choices of agents. It provides a risk measure more in line with their appetencies and behaviour. As we can find, the long-run betas are significantly different from the classic beta and this is true for the vast majority of equities. Following this example, Veolia has short-term betas slightly below the classic betas. In contrast, the mid and long run betas are significantly higher than the classic betas. This result confirms the previous observation: short-term betas are overestimated but long-term betas are underestimated (the reverse is possible for example with Vivendi). We conclude that the choice of agents is biased and this fact causes additional risks.

The advantage of using wavelet decomposition to limit these 'mistakes' on betas is significant. The rolling regressions specifically characterize this instability by analysing the volatility leading to an overview describ- 
ing the dynamics of rolling betas. This classification is repeated for each period. By analysing and comparing our results, we show that the systematic risk and its volatility are significantly different according to the investment horizon and the period. It provides additional degrees of freedom to make investment choices.

\section{References}

Black, F., M. Jensen, and M. Scholes. 1972. 'The Capital Asset Pricing Model: Some Empirical Test.' In Studies in the Theory of Capital Markets, edited by M. Jensen, 79-124. New York: Praeger.

Bos, T., and P. Newbold. 1984. 'An Empirical Investigation of the Possibility of Stochastic Systematic Risk in the Market Model.' Journal of Business 57 (1): 35-41.

Chan, L., and J. Lakonishok. 1993. 'Are the Reports of Beta's Death Premature?' Journal of Portfolio Management 19 (4): 51-61.

Fabozzi, F., and J.-C. Francis. 1978. 'Beta as a Random Coefficient.' Journal of Financial and Quantitative Analysis 13 (1): 101-16.

Fama, E., and J. MacBeth. 1973. 'Risk, Return, and Equilibrium: Empirical Tests' Journal of Political Economy 81 (3): 607-36.

Fama, E., and K. French. 1992. 'The Cross-Section of Expected Stock Returns.' Journal of Finance 47 (2): 427-65.

Gençay, R., F. Selçuk, and B. Whitcher 2005. 'Systematic Risk and Timescales.' Quantitative Finance 3 (2): 108-16.

Groenewold, P., and P. Fraser. 1997. 'Time-Varying Betas and Macroeconomics Influences.' Discussion paper 97.09, University of Western Australia, Crawley.

Hawawini, G. 1983. 'Why Beta Shifts as the Return Interval Changes.' Financial Analyst Journal 39:73-7.

Lintner, J. 1965. 'The Valuation of Risk Assets and the Selection of Risky Investments in Stock Portfolios and Capital Budgets.' Review of Economics and Statistics 47 (1): 13-37.

Mallat, S. 1989. 'A Theory for Multiresolution Signal Decomposition: The Wavelet Representation.' IEEE Transactions on Pattern Analysis and Machine Intelligence 11 (7): 674-93.

- 2001. Une exploration des signaux en ondelettes. Palaiseau Cedex: Ecole polytechnique.

- 2009. Wavelet Tour of Signal Processing: The Sparse Way. Amsterdam: Academic Press.

Markowitz, H. 1952. 'Portfolio Selection.' Journal of Finance 7 (1): 77-91.

Meyer, Y. 1990. 'Ondelettes et algorithmes concurrents.' Actualités mathématiques 12:217-81. 
Modigliani, F., G. Pogue, and B. Solnik. 1972. 'A Test of the Capital Asset Pricing Model on European Stock Markets.' Peper presented at the First International Congress on Stock Exchange, 14-16 March, Milan.

Mossin, J. 1966. 'Equilibrium in a Capital Asset Market'. Econometrica $34: 768-83$.

Newey, W., and K. West. 1987. 'A Simple, Positive Semi-definite, Heteroskedasticity and Autocorrelation Consistent Covariance Matrix.' Econometrica 55 (3): 703-8.

Sharpe, W. 1964. 'Capital Asset Prices: A Theory of Market Equilibrium under Risk. Journal of Finance 19 (3): 425-42.

Sharpe, W., and G. Cooper. 1972. 'Risk-Return Classes of New York Stock Exchange Common Stocks: 1931-1967.' Financial Analysis Journal 28 (2): 46-54.

This paper is published under the terms of the Attribution

NonCommercial-NoDerivatives 4.o International (CC B Y-NC-ND 4.O)

License (http://creativecommons.org/licenses/by-nc-nd/4.o/). 



\section{Role of Multidisciplinary and Interdisciplinary Education in Computer Science: \\ A Literature Review}

Kari-Pekka Heikkinen

Oulu University of Applied Sciences, Finland

kari-pekka.heikkinen@oamk.fi

Teppo Räisänen

Oulu University of Applied Sciences, Finland

teppo.raisanen@oamk.fi

Disruption of economies, caused by the Internet and communications technology and its effect to other industries, has had and will continue to have severe effect to the existing business models and production of goods for the upcoming decades. In addition, increasing complexity of global problems calls for the need of new problem solving competences. Complex problem solvers, knowledge workers, are more and more working by collaborative structures, where the solution creation benefits from multiprofessional way of working. This study is focusing on a trend of how higher education, especially in the area of computer science and engineering, is responding to the challenge of educating collaborative knowledge workers to a knowledge intensive work environment. The study was performed by a literature review covering publications indexed by the Scopus bibliographic database to find relevant research articles and reviews published between the years 2000 and 2016 . The results indicate a steadily growing interest towards multi- and interdisciplinary education. Most of the interest is indicated among the health care, medicine and nursing, and social sciences disciplines, while the interest among engineering and computer science is a clear minority. The results of this article can be used to study further the unused potential of engineering and computer science for the multi- and interdisciplinary education.

Key Words: higher education, interdisciplinary, multidisciplinary, interprofessional, computer science, engineering

JEL Classification: I23, L 86

https://doi.org/10.26493/1854-6935.16.159-172

\section{Introduction}

Globalisation and urban cities as hubs for economical development is a well-recognised phenomenon (e.g. Turunen 2015). In addition, the on- 
going shift from an economy based on physical inputs, land, capital and labour, to an economy based on intellectual inputs, or human creativity (Florida 2006) requires new ways of solving problems. By the collaboration of multiple stakeholders, defined as persons or parties with an interest at hand (Freeman 1984), human beings are expected to co-create new knowledge when collaboratively facing present complex societal problems. Within this collaboration multi-cultural, multi-disciplinary and multi-generational approach is often proposed to be an improved way of complex problem solving.

Complex and intangible problems solvers, so-called knowledge workers, are supposed to be lifelong learners who continually acquire and develop new knowledge. They must be able to critically select, acquire and use knowledge, wherever this is available (Engeström, Engeström, and Kärkkäinen 1995; Konkola et al. 2007) and by continually constructing and reconstructing their expertise in a process of lifelong learning (OECD 1996; Tynjälä 1999). In addition to their disciplinary skills the knowledge workers are expected to master and develop metaskills. Metaskills, such as learning by utilising networks, communication and critical thinking, have become as essential as discipline-specific skills. Individuals possessing these skills are exposed to the experience and the knowledge of other disciplines and thus are recognised as carrying the skills for knowledge creation (Nonaka and Takeuchi 1995) and crossing boundaries. Boundary crossing competence is defined to be the 'ability to manage and integrate multiple discourses and practices across different sociocultural boundaries' (Akkerman and Bakker 2011; Lansu et al. 2013; Umemoto 2001; Walker and Nocon 2007) and the ability to function competently in multiple contexts (Walker and Nocon 2007).

During the past decades the role of Internet and communications technology (ICT) in our society has increased significantly. The effect IC T has on businesses and to our daily life is often referred as a digital disruption (Koiranen, Räsänen, and Södergård 2016; Degryse 2016), which often means the use of IC T to change business models, as well as provide new revenue and value to companies and organisations. The digital disruption affects all industries and aspects of life whether it is the use of social media to increase sales or the use of emails to stay in contact with business partners and friends. As a summary, IC T is being used in all business sectors to provide added value for the companies. Realising above, the role of IC T in changing industries should be taken into account also in higher education, not just in the fields of computer science 
and engineering education. Also the opposite, since based on authors' background and experience, we claim that the computer science and engineering education would benefit greatly by the influence of other disciplines.

Higher education institutions globally have a significant role for educating new knowledge workers. Higher education is defined as an optional final stage of formal education that occurs after the completion of secondary education and is usually realised at universities, academies, colleges, seminaries, and institutes (UNESCO 1998). These education institutions are supposed to develop their education of knowledge workers towards to the needs of the surrounding society. Drawing together the society needs towards knowledge workers competences and growing utilisation level of IC T in other industries, the research questions in this article are defined as RQ1: 'What is the trend of interest towards multidisciplinary and interdisciplinary education in higher education?' and RQ2: 'Which disciplinary areas utilise the interdisciplinary and multidisciplinary in their higher education the most?' Main target for the research study in this article is to find and suggest topics and areas within the theme of multidisciplinary higher education for further research. In this article by the following chapters the terminology and methodology of the study, study results and the conclusions including further study proposals are described.

\section{Definitions of Collaborative Activity}

Definition of the collaboration between different professions or disciplines varies. The term 'disciplinarily' describes a somewhat traditional view of the academic discourses and is used to describe academic disciplines as autonomous and discrete areas of study. Across the disciplines independent academic communities rarely cooperate or coordinate their academic efforts. Academic disciplines, from this perspective, are discrete 'boxes', albeit with boundaries that may be permeable (Davies and Devlin 2007). The problem over time with the traditional notion of the academic discipline is that disciplines are not historically fixed; instead they evolve and change over time (Squires 1992). Academic disciplines are culturally and historically situated, are also defined by many attributes, and the relative emphasis on these different attributes can differ from discipline to discipline, even within each discipline (Davies and Devlin 2007). Traditionally healthcare has been the academic discipline utilising professional collaboration. The concept of health incorporates a complex and 
holistic system where biological, psychological, physical, socioeconomic, cultural, and environmental factors function as interconnected and interacting determinants of one another (Weiss et al. 2018). Collaboration, defined as two or more people involved and engaged in interaction with each other, within a single episode or series of episodes and working towards common goals (Patel, Pettitt, and Wilson 2012), definitions used often in a work context are interprofessional, interdisciplinary and multidisciplinary collaboration.

Interprofessional refers to a collaboration using several professionals that are collaborating with each other. It can be pretty simple, for instance in the case of healthcare interprofessional education 'involves educators and learners from 2 or more health professions and their foundational disciplines who jointly create and foster a collaborative learning environment. The goal of these efforts is to develop knowledge, skills and attitudes that result in interprofessional team behaviours and competence' (Buring et al. 2009; D'amour and Oandasan 2005.) Ideally, you can have a patient that is accessing different services and they may speak to each other to agree on a care plan. Interprofessional connotes the working relationship of people who have differing areas of professional expertise.

Multidisciplinary has been described more simply as the view that: 'everyone [does] his or her thing with little or no necessity for any one participant to be aware of any other participant's work' (Petrie 1976). Multidisciplinary is the co-existence of a number of disciplines. It is no more intellectually, or academically, illuminating than what typically exists in higher education degrees. In health care, multidisciplinary isn't just a collaboration of random professionals but a system, which creates good outcome for patients by utilizing different healthcare disciplines. In education, multidisciplinary recognises the fact that there are many discrete and autonomous disciplines. While students normally specialise in one discipline, they can study several over the course of a typical degree program. (Davies and Devlin 2007). For example, in addition to accounting subjects, an accounting student also studies some subjects in finance, and may also study some economics, and/or disciplines such as history or music.

Klein (1990) distinguishes interdisciplinary from multidisciplinary as more than one discipline working on the same problem, but with no real conversation. Interdisciplinary is a model not just random professionals speaking to each other, rather it refers to the combination of more than one area of knowledge. Unlike multidisciplinary, where disciplinarians 
need not discuss things with each other, this variant requires 'more or less integration and even modification of the disciplinary sub-contributions while an inquiry is proceeding' (Davies and Devlin 2007). Different participants need to take into account the contributions of their colleagues to make their own contribution (Petrie 1976). In the health care this model is inclusive to difference disciplines (nursing, medicine, psychosocial/social justice) to better the patient's health. The model tends to be holistic and expanded through different points of care, so professionals are discussing the patient's health and future health where every aspect of care is part of the care plan. Interdisciplinary can also be an academic term when two areas of academic interest cross and fill a gap of knowledge. So, for instance, information technology and nursing would be nursing informatics. The higher education interdisciplinary is regarded simply as elective subjects taken from a variety of disciplines that in some way relate to a general topic. Here there are 'two or more disciplines [...] contributing their particular disciplinary knowledge on a common subject' (Garkovich 1982).

Moving further along the continuum of variants of interdisciplinary, at one extreme is a view of interdisciplinary as involving the 'collapse of academic borders and the emergence of a new discipline' (Davidson 2004). This is sometimes known as 'transdisciplinary' (MaxNeef 2005). However, dissolving academic boundaries would seem to go against the gains won in terms of the basic research productivity of individual disciplines. There are questions about how, in a practical sense, disciplines would continue work done in dedicated disciplinary areas of concern if boundaries were 'dissolved' and about how disciplinary integrity would be maintained. If boundaries between disciplines are dissolved, it becomes unclear to what extent traditional disciplines would survive, although some temporary boundary dissolution may lead to new disciplines (S. Marginson, personal communication, 27 April 2007). In the process of solving problems that are characterised by increased complexity, transdisciplinary can enlighten new points of view for the solutions and thus enhance creativity for innovations.

\section{Methodology}

The study was done by a literature review for the articles or reviews published between the years 2000 and 2016 within the higher education context. By the literature review methodology a general overview of the phenomenon can be achieved (Kothari 2004), as the published ar- 
TABLE 1 Scopus Bibliographic Database Science Classification

\begin{tabular}{ll}
\hline Computer & General Computer Science, Computer Science (miscellaneous), Artifi- \\
cial Intelligence, Computational Theory and Mathematics, Computer \\
Graphics and Computer-Aided Design, Computer Networks and Com- \\
munications, Computer Science Applications, Computer Vision and \\
Pattern Recognition, Hardware and Architecture, Human-Computer \\
Interaction, Information Systems, Signal Processing, Software
\end{tabular}

Continued on the next page

ticles and reviews are indicating the interest towards the subject from various topical angles. A search for the scientifically published articles or review papers was directed to Scopus, one of the biggest bibliographic databases having more than 69 million records today (see https://www.scopus.com). For gaining a result-set to be analysed altogether three individual searches with different keywords were performed. For this result-set the analysis was performed in two different parts to study each research question, RQ1 and RQ2, separately.

The searches were performed for the title, abstracts and keywords of the articles and reviews published between the years 2000 and 2016 by us- 
TABLE 1 Continued from the previous page

\begin{tabular}{ll}
\hline Nursing & General Nursing, Nursing (miscellaneous), Advanced and Specialised \\
& Nursing, Assessment and Diagnosis, Care Planning, Community and \\
& Home Care, Critical Care, Emergency, Fundamentals and skills, Geron- \\
& tology, Issues, ethics and legal aspects, Leadership and Management, \\
& LPN and LV N, Maternity and Midwifery, Medical-Surgical, Nurse As- \\
& sisting, Nutrition and Dietetics, Oncology (nursing), Pathophysiology, \\
& Paediatrics, Pharmacology (nursing), Psychiatric Mental Health, Re- \\
& search and Theory, Review and Exam Preparation \\
\hline Social & General Social Sciences, Social Sciences (miscellaneous), Archaeol- \\
Sciences & ogy, Development, Education, Geography, Planning and Development, \\
& Health(social science), Human Factors and Ergonomics, Law, Library \\
& and Information Sciences, Linguistics and Language, Safety Research, \\
& Sociology and Political Science, Transportation, Anthropology, Com- \\
& munication, Cultural Studies, Demography, Gender Studies, Life-span \\
and Life-course Studies, Political Science and International Relations, & Public Administration, Urban Studies \\
\hline
\end{tabular}

notes Adapted from https://www.scopus.com.

ing keywords. Keywords used were: 'interdisciplinary higher education, 'multidisciplinary higher education' and 'interprofessional higher education.' The search produced the result-set of total amount of 6328 articles or reviews, which was analysed by the Scopus bibliographic database analysis tool (see https://www.scopus.com). The analysis tool provides information from the result-set broken down by year, source, author, affiliation, country, document type and subject area. In case of analysis for the $\mathrm{RQ1}$, the result-set was analysed by the used keywords and publication year. For the analysis of the RQ2, the Scopus analysis tools Subject area classification was used. The classification identifies and categorises the published research into different disciplines and its sub-areas. In addition to the subject under this study, computer science and engineering, table 1 summarises the sub-areas of the three Subject areas; medicine, nursing, social sciences and engineering.

\section{Results}

The first research question of this paper, RQ1, focuses on the trends of higher education in regards to multidisciplinary and interdisciplinary education. Figure 1 illustrates four graphs as a summary of the first analysis. The graph 1 illustrates the amount of publications and articles or reviews published yearly between the years 2000 and 20016. The graph on the top is summarising the amount of articles and reviews published having 'in- 


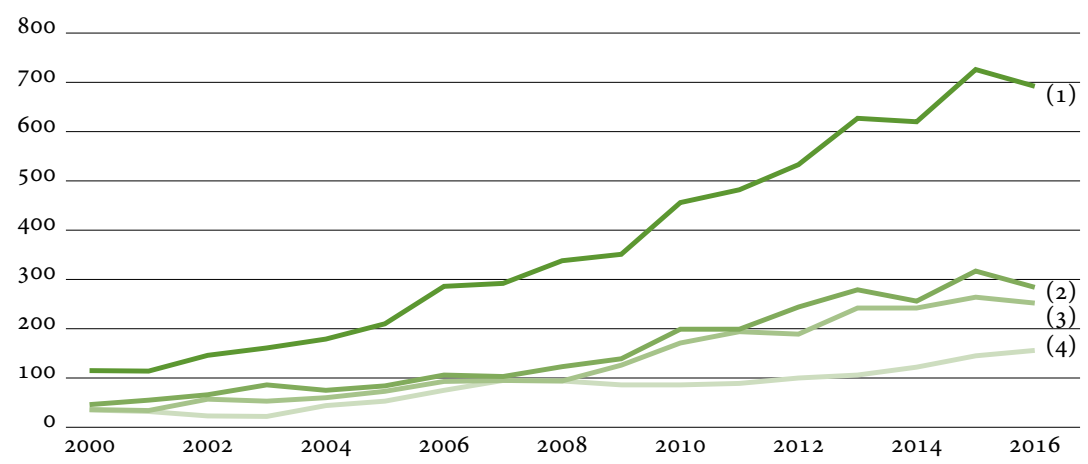

FIGURE 1 Publications in Scopus by Matching Keywords between the Years 2000-2016 ( 1 - total, 2 - interdisciplinary higher education, 3 - multidisciplinary higher education, 4 - interprofessional higher education)

terdisciplinary,' 'multidisciplinary' or 'interprofessional' and 'higher education' in their title, abstract or keywords.

The figure 1 shows that the total amount of articles has been growing steadily over time between the years 2000 and 2016. In year 2000 there was together 115 articles published, in year 2010 together 456 articles published and the highest amount of articles so far, 726, was published on year 2015. The growing number of yearly-published articles indicates the researchers' interest towards the importance of the role of interdisciplinary, multidisciplinary and interprofessional education.

Between the years 2000 and 2007 in the figure 1 the three lower graphs, interdisciplinary, multidisciplinary and interprofessional higher education, seem to grow on a similar pace. After the year 2007, the interprofessional education research seems to grow in a lower pace, even to decrease, compared to the other two that keep a similar pace all the way to year 2016. These two graphs, which illustrate the amount of articles published focusing either multidisciplinary or interdisciplinary higher education, are growing about the same rate, so there is no clear distinction that one of the topics would have been published more than the other. In year 2000 there were 35 articles published on interdisciplinary higher education while multidisciplinary higher education 46 articles published. In 2016 the former had 284 articles published while the latter had 252 published. This possibly indicates the interest towards interdisciplinary higher education research. The indication seems logical because the needs for boundary crossing competences and metaskills for knowledge workers might benefit more from interdisciplinary style of education. 


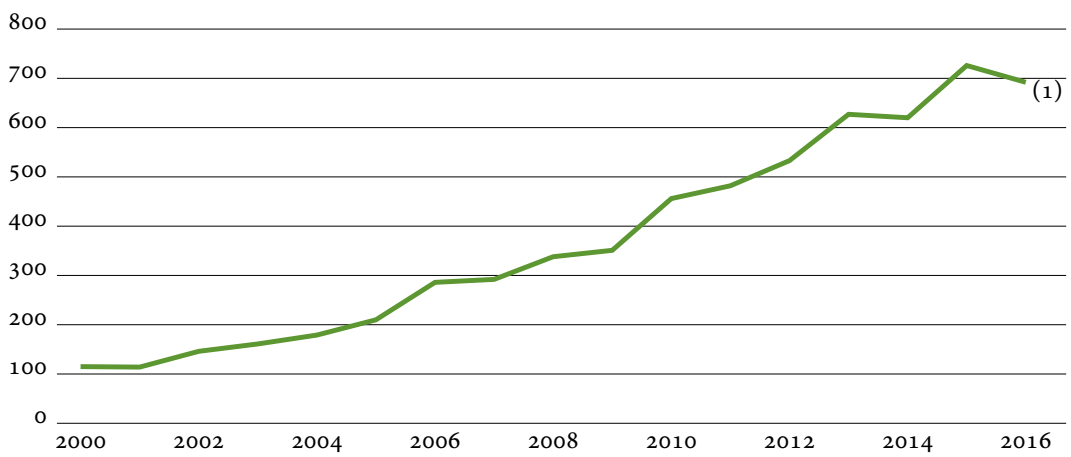

FIGURE 2 Publications in Scopus by the Subjects and Matching Keywords between the Years 2000-2016 (1 - all fields)

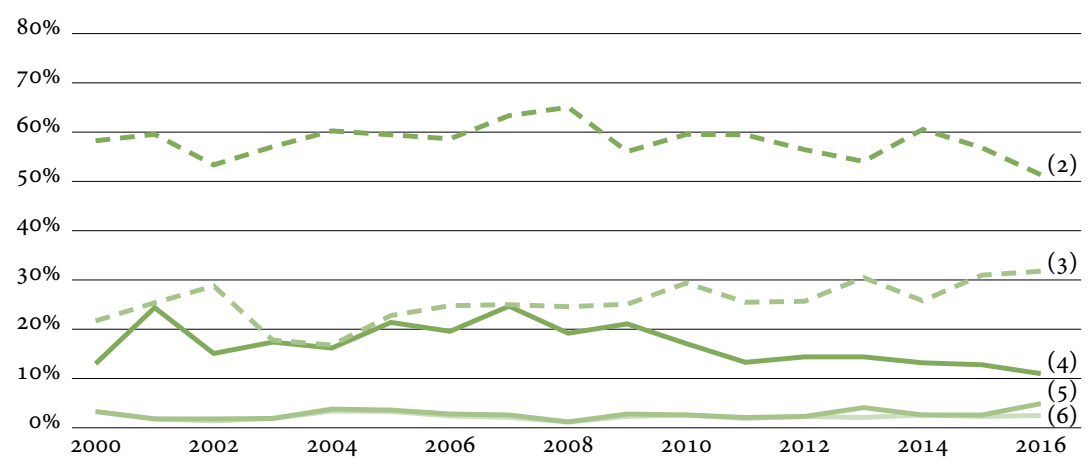

FIGURE 3 Publications in Scopus by the Subjects and Matching Keywords between the Years 2000-2016 (2 - medicine, 3 - social sciences, 4 - nursing, 5 engineering, 6 - computer science)

The second research question, RQ2, focuses in which disciplines interdisciplinary, multidisciplinary and interprofessional higher education is utilised the most. In the study a more detailed analysis for the previously searched result-set was performed. Figures 2 and 3 illustrate six different graphs as a summary of the second analysis. The graph on the top is the same than in the figure 1, displaying the total number of articles or reviews in Scopus that match either 'interdisciplinary', 'multidisciplinary' or 'interprofessional' and 'higher education' in their title, abstract or keywords.

The graphs in figures 2 and 3 illustrate the following subjects, their amount and relative share of the total articles or reviews published yearly between the years 2000 and 20016 . The graph 1 (in figure 2) is the total number of published articles or reviews. In figure 3 the five graphs 
illustrate how the relative share of published articles has changed over the years in selected fields. The second graph in figure 3 is medicine, the third graph is social sciences, the fourth graph is nursing, the fifth graph is engineering and the sixth is computer science. From the figures 2 and 3 it can be seen that the interest towards of interdisciplinary, multidisciplinary and interprofessional education is a growing trend on all of the studied disciplines except nursing. Traditionally the disciplines publishing the most have been the medicine and social sciences. The interdisciplinary, multidisciplinary and interprofessional higher education publications on medicine has maintained its popularity over the time, while the relative amount of social sciences publications has been increased steadily. Nevertheless, these two disciplines publish by far the most articles on multidisciplinary, interdisciplinary and interprofessional education. For example, from the graphs can be seen that in $200058.3 \%$ of all articles or reviews published where on medicine. In 2016 the share of all articles on medicine was $51.4 \%$. So, even if the total number of articles or reviews on medicine has increased from 67 in 2000 to 356 in 2016, the relative share of publications is down only by $6.9 \%$. The share of social sciences' publications has been growing steadily from $21.7 \%$ to $31.8 \%$. This indicates that most likely importance of social sciences will remain high also in the future.

Third graph in figure 3 illustrates that nursing's publications amounts has stayed about the same from 2000 to 2016 . However, the graph indicates the decreasing trend of relative publication rate, since between 2005 and 2009 the rate was around $20 \%$ and since 2010 closer to even $10 \%$. The last two graphs illustrate the engineering and computer science publication amounts, thus indicating publication rates to remain relative low for most of the time period. Engineering publication rate has remained less than 3.5\% for the most time period, as small growth has appeared within the last years. Computer sciences publication rate has imitated the somewhat similar path than engineering, staying less than $3.5 \%$ in the relative amount of publications. The difference between the engineering and computer science publication rate has been only during the year 2016, prior to that both of them the publication rate has grown almost identical.

\section{Conclusion}

In this article we studied the trend of multidisciplinary, interdisciplinary and interprofessional higher education. The study was focusing whether 
this kind of teaching was gaining more attention in the 200os, and, in addition, to know what fields of research were mostly taking the advantage of interdisciplinary, multidisciplinary and interprofessional teaching. The results indicate that the general research interest towards collaborative learning in higher education has been growing steadily between the years 2000 and 2016. Interdisciplinary, multidisciplinary and interprofessional ways of education have gained around the same amount of interest during the above-mentioned time frame. The yearly amount of research publications has grown from year 2000's 115 articles or reviews to around 700 in years 2015 and 2016. This result indicates that the researchers and educators have noted the importance of multidisciplinary, interdisciplinary and interprofessional higher education.

Based on the results there is a strong indication that interdisciplinary, multidisciplinary and interprofessional education is not as common among computer science and engineering higher education studies as it is in e.g. healthcare or social sciences. Looking more closely on the different subjects of research we can see that medicine, social sciences and nursing have stayed the most productive areas for publications. Out of these three the number of articles written in medicine and social sciences has increased steadily, while the number of published articles in nursing has not increased. In the field of computer science and engineering the relative amount of publications compared to other fields has remained steady but not significant.

Engineering and computer science seems to be the two fields where especially interdisciplinary and multidisciplinary education has room to grow. Because of digital disruption, the use of computing and IC T in general is expanding into new industry areas, the role of computer science will be increased in the solutions (e.g. services and products) development as well. Most study programmes overall could benefit from multidisciplinary or interdisciplinary teaching due to increasing need of computing, as well as digitised products and services. Thus, potentially the number of scientific articles in the field of computer science that focus especially on interdisciplinary and multidisciplinary education will increase in the future. In addition, since the authors of this article are from computer science and engineering, based on our experience teachers on these disciplines tend to more likely focus on content and less on pedagogy. Thus there's a great demand for interdisciplinary and multidisciplinary mind-set to grow in the computer science and engineering fields of education. 
Potential limitation of this study is the correlation of published research papers and actual educational activities performed in higher education institutions. In other words, if there is an indication of increased research interest towards interdisciplinary and multidisciplinary education, does it also mean increased amount of education offered by such way? On the other hand, there can be interdisciplinary and multidisciplinary education programs that are not reported by academic publications. Nevertheless, according authors opinion this is true for all fields of study and it doesn't skew the results one way or the other. In addition, the study was focusing on search titles, keywords and abstracts from the articles and papers from Scopus bibliographic database. For this the authors trust that Scopus' classification of articles is correct and that the articles indexed in Scopus offer a good representation of all research performed in the area of interdisciplinary and multidisciplinary research on higher education.

Another possible limitation for this study is the Subjects classification provided by Scopus bibliographic database. From the table 1 it can be seen that the medicine has the most sub-areas under the Subjects classification. Potentially this could correlate to the total amount of publications in medicine, and effect to the study in number of articles published. Still the results regarding the relative amounts of publications between different studied subjects, shows a clear distinction between the most active (medicine, social sciences and nursing) and less active (computer science and engineering) subjects of publishers. In addition, the longer heritage of professional collaboration in health care probably affects to the amount of publications.

As a future research we propose to continue study towards more detailed analysis of the articles and reviews found. By analysing the abstracts of all computer science and engineering classified articles and reviews, the types of interdisciplinary, multidisciplinary or interprofessional teaching they offer can be studied. Also by studying the publications of the major universities and colleges, we propose to find the current state-of-the-art interdisciplinary and multidisciplinary education program curricula. We also propose to study if there are any special requirements that computer science or engineering poses for interdisciplinary and multidisciplinary education. Finally, we propose to replicate this study within couple of years to see whether the role of interdisciplinary, multidisciplinary and interprofessional research has increased especially in the field of computer science or engineering. 


\section{References}

Akkerman, S. F., and A. Bakker. 2011. 'Boundary Crossing and Boundary Objects.' Review of Educational Research 81 (2): 132-69.

Buring, S. M., A. Bhushan, A. Broeseker, S. Conway, W. Duncan-Hewitt, L. Hansen, and S. Westberg. 2009. 'Interprofessional Education: Definitions, Student Competencies, and Guidelines for Implementation.' American Journal of Pharmaceutical Education 73 (4). https://doi.org/ 10.5688/aj730459

D'Amour, D., and I. Oandasan. 2005. 'Interprofessionality as the Field of Interprofessional Practice and Interprofessional Education: An Emerging Concept.' Journal of Interprofessional Care 19 (1): 8-20.

Davidson, M. (2004). 'Bones of Contention: Using Self and Story in the Quest to Professionalize Higher Education, An Interdisciplinary Approach.' Teaching in Higher Education 9 (3): 299-310.

Davies, M., and M. T. Devlin. 2007. 'Interdisciplinary Higher Education: Implications for Teaching and Learning.' Centre for the Study of Higher Education, University of Melbourne.

Degryse, C. 2016. 'Digitalisation of the Economy and its Impact on Labour Markets.' WP 2016.02, ET UI, Brussels.

Engeström, Y., R. Engeström, and M. Kärkkäinen. 1995. 'Polycontextuality and Boundary Crossing in Expert Cognition: Learning and Problem Solving in Complex Work Activities.' Learning and Instruction 5 (4): $319-36$.

Florida, R. 2006. 'The Flight of the Creative Class: The New Global Competition for Talent.' Liberal Education 92 (3): 22-9.

Freeman, R. E. 1984. Strategic Management: A Stakeholder Approach. Boston, MA: Pitman.

Garkovich, L. 1982. 'A Proposal for Building Interdisciplinary Bridges' Teaching Sociology 9 (2): 151-68.

Klein, J. T. 1990. Interdisciplinarity: History, Theory, and Practice. Detroit, MI: Wayne State University Press.

Koiranen, I., P. Räsänen, and C. Södegård. 2016. 'Mitä digitalisaatio tarkoittaa kansalaisen näkökulmasta?' Talous ja yhteiskunta, no. 3:24-9.

Konkola, R., T. Tuomi-Gröhn, P. Lambert, and S. Ludvigsen. 2007. 'Promoting Learning and Transfer between School and Workplace'. Journal of Education and Work 20 (3): 211-28.

Kothari, C. R. (2004). Research Methodology: Methods and Techniques. New Delhi: New Age.

Lansu, A., J. Boon, P. B. Sloep, and R. van Dam-Mieras. 2013. 'Changing Professional Demands in Sustainable Regional Development: A Curriculum Design Process to Meet Transboundary Competence.' Journal of Cleaner Production, 49:123-33. 
Max-Neef, M. A. 2005. 'Commentary: Foundations of Transdisciplinarity' Ecological Economics 53:5-16.

Nonaka, I., and H. Takeuchi. 1995. The Knowledge-Creating Company: How Japanese Companies Create the Dynamics of Innovation. New York: Oxford University Press.

OECD. 1996. Lifelong Learning for All. Paris: OECD.

Patel H., M. Pettitt, and J. R. Wilson. 2012. 'Factors of Collaborative Working: A Framework for a Collaboration Model.' Applied Ergonomics 43 (1): $1-26$.

Petrie, H. G. 1976. 'Do You See What I See? The Epistemology of Interdisciplinary Inquiry'. Educational Researcher 5 (2): 9-15.

Squires, G. (1992). 'Interdisciplinarity in Higher Education in the United Kingdom.' European Journal of Education 27 (3): 201-10.

Turunen, A. (2015). Maailmanhistorian kukoistavimmat kaupungit. Helsinki: Into.

Tynjälä, P. (1999). 'Towards Expert Knowledge? A Comparison between a Constructivist and a Traditional Learning Environment in the University'. International Journal of Educational Research 31 (5): 357-442.

Umemoto, K. (2001). 'Walking in Another's Shoes: Epistemological Challenges in Participatory Planning.' Journal of Planning Education and Research 21 (1): 17-31

unEs CO. 1998. 'Higher Education in the Twenty-First Century: Vision and Action.' http://unesdoc.unesco.org/images/oo11/oo1163/116345e.pdf

Walker, D., and H. Nocon. 2007. 'Boundary-Crossing Competence: Theoretical Considerations and Educational Design.' Mind, Culture, and Activity 14 (3): 178-95.

Weiss, D., D. Weiss, F. J. Tilin, and M. J. Morgan. 2018. The Interprofessional Health Care Team. Burlington, M A: Jones \& Bartlett Learning.

This paper is published under the terms of the Attribution-

NonCommercial-NoDerivatives 4.o International (CC B Y-NC-N D 4.0)

License (http://creativecommons.org/licenses/by-nc-nd/4.o/). 


\title{
Sustainability of the Pension System \\ in the Republic of Macedonia: \\ Challenges and Solutions
}

\author{
Hyrije Abazi-Alili
}

South East European University, Macedonia

h.abazi@seeu.edu.mk

Shpresa Alija

South East European University, Macedonia

s.alija@seeu.edu.mk

Abdylmenaf Bexheti

South East European University, Macedonia

a.bexheti@seeu.edu.mk

Irina B. Panovska

Lehigh University, USA

irp213@lehigh.edu

Remzije Rakipi

South East European University, Macedonia

r.rakipi@seeu.edu.mk

The aim of the study is to create a forecasting model that will foresee the trend of the situation of the Pension, Insurance and Disability Fund of the Republic of Macedonia. The methodology applied to evaluate the sustainability of pension system, and controlling the risk to pension funds, is forecast of all individual regressors through first order autoregressive model. This method will enable the assessment of the future uncertainty of the contributions and expenditures of pension insurance. The forecasted data show that in 2056, if no other reforms are undertaken, the increase in the percentage points of the number of employers is less than the increase in the number of pensioners for 3.9 percentage points. As per the natality and mortality, in the Republic of Macedonia natality will be only one third of its statistics in 2016, whereas mortality will double its value by 2056 .

Key Words: pension sustainability, postponed retirement, contributions and expenditures, financial and demographic forecasting, transition economy

JEL Classification: H55, J26, J11

https://doi.org/10.26493/1854-6935.16.173-187 


\section{Introduction}

The pension system represents a constant challenge both for lawmakers, regulators and pensioners. The main struggles of the pension and retirement policies are to provide adequate income in old age while at the same time guaranteeing financial sustainability and keep high level of employment. The key dilemma of many developed and transitional countries is precisely the direction of the development of the pension system, namely its structure and performance.

Since the founding of the pension system in the Republic of Macedonia, it has been operating on the basis of the principle of solidarity between generations and aims to create funds for pensioners and to maintain the almost equal level of living.

The pension system, according to Gora (2008) is a tool that divides the current GDP between the working generation and the pensioners. $\mathrm{He}$ also emphasizes that the higher share of GDP allocated to the inactive would enable the lower remuneration of production factors supplied by the active, which has consequences on economic growth, conditions in the labour market and the distribution of poverty. Furthermore, Blake (2006) claims that the distribution of the GDP between the working generation and the pensioners is elaborated in-depth by the overlapping generation model (OLG), as a very powerful tool to analyse pension systems.

The sustainable development of the pension system has a close relationship with social harmony as well as economic sustainable development (Dorfman et al. 2013). Therefore, keep long-term balance of contributions and expenditures of the pension system is crucial for accomplishing sustainable development of the system, meaning that financial sustainability should be maintained.

The protection of the elderly is one of the most important part of the pension system (Grech 2010). Taking into consideration the acceleration of the aging evolution of the population, the pension fund is confronted with many challenges to maintain financial stability.

The operation based on the principle of solidarity was initially considered successful and challenging during its implementation, as the average life expectancy was approximately 55 years and the employed ratio was 7 : 1 pensioner. However, later on, due to changes in the demographic structure, difficulties were encountered in implementing the principle of solidarity between generations, stemming from an increase in average human life expectancy and a reduction in the employed-retired ratio. 
Demographic structural changes that directly determine the movement of pension income caused worsening in pension systems, the creation of debts on pension funds, i.e. the pursuit of pension reforms worldwide. By 2007 around 170 countries adopted and approved some reforms in their pension systems aimed at realizing the rights of pension and disability insurance for all generations, short-term and long-term realization of solvency, not to override the reinforcement of public confidence and stimulating the development of capital markets, thus encouraging economic growth.

The following section provides some literature review on the issue of the methodology used to forecast the sustainability of the pension system, and some factors that influence the financial sustainability. Section 3 describes the data and presents the methodology used in the study. Section 4 provides the findings and discussion of the results. The concluding remarks are provided in section 5 .

\section{Literature Review}

The pension system, i.e. the sustainability of the pension system continues to remain part of the economic discourse. Population aging presents the main problem, which become even more difficult if it is accompanied by a PAYG scheme. It also known that in recent decades the financial sustainability of pension systems, in developed and developing countries is permanently threatened by the demographic factors (such as fertility, life expectancy, old-age, dependency ratio) and by the slowdown of growth rates economy.

Consequently, many countries have adopted radical reforms in their pension systems which are currently being implemented. The reforms in question had to do precisely with the transformation of pension systems from the nonfinancial model to the hybrid (financing and nonfinancing), or completely into the financial model. However, this transformation of pension systems has not yet been able to solve the problem of insolvency of pension system, because the demographic factors are not the only source of this lack of ability, which means that this insolvency includes a set of others factors such as labour market factors, national product, educational attainment, income adequacy of pensions, etc.

According to the International Monetary Fund Report (2012), 'Threats to financial stability from longevity risk derive from at least two major sources: one is the threats to fiscal sustainability as a result of large longevity exposures of governments (which, if realized, could push up 
debt-to-GDP ratios more than 50 percentage points in some countries) and the second factor is possible threats to the solvency of private financial and corporate institutions exposed to longevity risk. The latter, make us aware that longevity risk threatens to undermine fiscal sustainability of pension systems in the coming years and decades and complicating the longer-term consolidation efforts in response to the current fiscal difficulties. Therefore, reforms of the pension system model are intended to challenge these inappropriate demographic trends and are expected (the funded or at least partly funded) to prove resistant to negative demographic factor.'

Thus, relying on the Diamond-Samuelson olg model, when labour supply and retirement are exogenous and when a state pension system that is fully funded is introduced, there will be no change to the dynamic path of the economy, which means that it is impossible to move from an unfunded to a funded pension scheme without making the transition generation worse off. Instead, when labour supply and retirement are endogenous, and respond to the taxes, as is possible to move gradually from an unfunded to a funded scheme.

So, what happens during the transition from PAYG schemes into fully funded pension schemes? The latter, is well argued by Feldstein and Liebman (2001) in a paper where they asses the theoretical and empirical implications of the transition from the PAYG schemes into fully funded pension schemes with investment-based individual savings accounts, where they highlighted the fact that even though the introduction of the PAYG schemes (which benefitted older age cohorts), a considerable strain is imposed on the younger generations facing a small internal rate of return on mandatory contributions into PAYG public schemes.

However, in both, the unfunded and funded pension system there is no other way of pension funding than through GDP distribution, even if the distribution differs from these systems. Thus, in the unfunded system, the distribution occurs without the involvement of the financial market - based on the promises that in return for the submitted contributions, a pension benefit will be paid out in the future). While in the funded model the distribution is made with the participation of the financial market, and the amount of the future pension benefit received in return for the contributions, depends on the rate of return on this market. Barr and Diamond (2006), emphasize the way of how the distribution is conducted between the working generation and the pensioners, i.e. the mentioned promise of sharing part of the future GDP with the generation of pen- 
sioners that may be given by children to their parents, by businesses to their employees, and by the government to citizens - depending on the type of pension security.

In general, the theoretical aspect of the pension systems (including the factors that affect it), help us recognize another important factor for the solvency of pension systems, which are the pension expenditures as a result from the distribution of the current GDP between the pensioners and the working generation (by not excluding the other factors which have a crucial impact in increasing or decreasing the participation of pension expenditures in GDP, such as labour market, the level of GDP growth, income adequacy of the pension system, education of people, etc.). Education, as another factor that affects the pension expenditures relates to the equality and rationality of pension decisions that may affect the distribution of current GDP, i.e. the pensioners' participation in funds. According to Blake (2006), better education is one of the factors extending life expectancy. The latter, let us know that in countries with a higher percentage of educated people, the pension expenditures are expected to be higher, which may be attributed to the fact that educated people, live longer. However, the best way of analysing the pension expenditures is through measurement. There are various ways to assess the financial sustainability of pension systems. The other way of measurement of pension expenditures is by comparing the results from equations of pension system incomes from contributions and expenses for pension benefits, which was used by e.g. De la Fuente (2011). Further, measuring the pension expenditures in absolute values or in relation to GDP, is definitely more legitimate because enables comparing these expenses throughout many countries with various GDP's.

Taking in consideration the findings of the authors related to the oldage pension expenditure as well as based on the pension economy theory, we may list some of the important groups of factors determining pension expenditure, such as demographics, the labour market, GDP and its growth, income adequacy of pensions and education. Although, the concerned factors do not exhaust the issue of pension system solvency determinants, nevertheless they seem to be of highest significance in the context of pension reforms.

Therefore, to evaluate the sustainability of pension systems, different models and perspectives are now being used, reflecting different results (Long and Pfau 2008). For example, Lee and Tuljapurkar (1994) in their successive studies, to see the impact of demographic change on the finan- 
cial sustainability of the Us pension system, by creating stochastic forecasts for mortality and using a deterministic forecast for net immigration, made a prediction of the Us population, for the period 1994-2070.

Furthermore, Fehr and Habermann (2004), using the combination of demographic and economic factors, dealt with the sustainability of the German pension system under the influence of the uncertainty of demographic factors for the period 2001-2050. So, the authors use stochastic forecasts for fertility and mortality, while an overlapping generation model (including 3 sectors: household, production, and government) is used for economic variables. The results found that demographic changes play an important role in the level of benefits for the long term, suggesting concentration in contribution rates and replacement rates.

The Asset-Liability Model (ALM) with stochastic simulation is used for analysing the Japanese pension scheme by Chia, Kitamura, and Tsui (2004). The authors take in consideration different variables (growth rate of wages, investment return, etc.), to determine an appropriate index of pensions, which at the same time will affect the level of future benefits and the financial sustainability of the scheme. Also, Børlum (2004), following the previous author's methodology, in his study of the Danish pension system, came to the conclusion that the insecurity of demographic factors has a significant impact on long-term profit levels.

However, Moscarola (2009) in assessing the sustainability of the Italian pension system, use Microsimulation Model, which came to conclusion that cohorts that fall completely under the new system accrue present value ratios calculated at the $1.5 \%$ real interest rate of around 1 on average. Also, Fernandez-Diaz, Patxot, and Souto (2013) by using the previous model (DyPeS, the first dynamic microsimulation), in assessing the sustainability of the Spanish pension system came to the conclusion that in the simulations adopted in 2011 only the increase of retirement age (from 65-67) will have an important effect on pension expenditures, while the other measures applied in calculating the initial pension for new retirees have a limited impact.

A microsimulation model is used by Hanappi, Müllbacher, and WinterEbmer (2012), for assessing Austria's pension system. The data was collected by the Austrian social security database (ASSD). The implementation of this model enables the calculation of the pension benefits rights for each individual. During the simulation of some pension reform scenarios, they noted that a stronger emphasis on the financial incentives of the pension system (bonuses or additional deductions) reduces the out- 
of-labour-force ratio of individuals aged $55-65$ by $16.3 \%$ for females and $13.4 \%$ for males. So, for measuring the financial sustainability of pension systems, different authors employ different models (Overlapping Generation Model, Life cycle model, Microsimulation model, Stochastic forecasting model etc.), which also come with different findings, depending on the problem's point of view. In our study, we apply individual forecast of all individual regressors, to evaluate the trends of the pension system of Republic of Macedonia.

The variables employed are: number of pensioners, number of employers, budget income, income from pension contributions, expenditure for pensions, pension age factor, etc. Hence, the generated results will serve as recommendation for the Republic of Macedonia, i.e. in order to achieve financial consolidation of the pension system RM will need to either: (i) raise the contribution rate, actually return to the previous rate of $21.2 \%$; increasing the age retirement, or in parallel, increasing the contribution rate and increasing the retirement age.

\section{Data Analysis and Methodology}

The aim of this study is to provide forecast of all individual regressors using basic arima models, to evaluate the trends of different variables related to the pension system of the Republic of Macedonia. A time series is a sequence of measurements of the same variables made over time. The measurements of the data employed in this paper are yearly. Generally, an autoregressive model is when a value from a time series is regressed on previous values from that same time series.

$$
y_{t}=\beta_{\mathrm{o}}+\beta_{1} y_{t-1}+\varepsilon_{t} .
$$

In this regression model, the response variable in the previous time period has become the predictor and the errors have the usual assumptions about errors in a simple linear regression model. The order of an autoregression is the number of immediately preceding values in the series that are used to predict the value at the present time. So, the preceding model is a first-order autoregression, written as $\mathrm{AR}(1)$.

The data employed for the estimation of AR(1) are historical timeseries annual data for financial and demographical characteristics of the Macedonian population for the period 1994 until 2016. The data are available from official sources such as the Pension and Disability Insurance Fund, State Statistical Office and Ministry of Finance of the Republic of Macedonia. 
Number of Pensioners Data. This paper takes the number of pensioners data from 1994 until 2016. According to the data the number of pensioners has increased from 216.83 thousand in 1994 to 305.77 thousands of pensioners in 2016, indicating that there is an increase of approximately $41.2 \%$.

Number of Employers Data. In order to have a comparative indication of employer-to-pensioner ratio, statistics on the number of employed persons are provided. In the Republic of Macedonia, there is an increase on the number of employers from 468 thousand in 1994 to 570 thousands of employers in 2016, indicating that there is an increase of approximately $21.8 \%$.

Number of Employers per Pensioners Data. As it can be seen from the above mentioned variables, because of the higher increase in the trend of the number of pensioners than the numbers it is expected that this ratio will decrease. That is, a decrease from 2.2 in 1994 to 1.9 in 2016. This is the most concerning ratio between the number of employers and number of pensioners from the beginning of transition when it was 3:1 until 1.9:1 (1.9 of the employers pay contribution for every pensioner in the Republic of Macedonia). This ratio is even worse in 2002 being 1.3:1 (the years after the conflict in the country). However, due to the Ohrid Framework and increase in the employment in the public sector there is a slight improvement in this ratio (Centre for Regional Policy Research and Cooperation 'Studiorum' 2011).

Natality Data. There is a decreasing trend of Natality in the Republic of Macedonia. Specifically the natality has fallen from 31 thousand in 1994 to 23 thousands of inhabitants in 2016 , i.e. decreasing rate of $25.8 \%$ for the years under analysis.

Mortality Data. On the other hand, there is an increasing rate of mortality from 15.6 in 1994 to 20.4 thousand in 2016, indicating that there is an increase of approximately $30.7 \%$.

Budget Income Data. The data consists of four financial variables. One of them is budget income. The trend is positive, i.e. there is a considerable increase from 2,944.6 in 1994 to 26,599.5 (in thousands of denars, 100 denar $=1.62$ euro) in 2016 .

Income From Pension Contributions. The other financial variable is income from pension contributions. Again, the trend is positive, i.e. there is an increase from $13,634.7$ in 1994 to $32,488.8$ (in thousands of denars) in 2016.

Total Budget Expenditure. The data on total budget expenditure show 

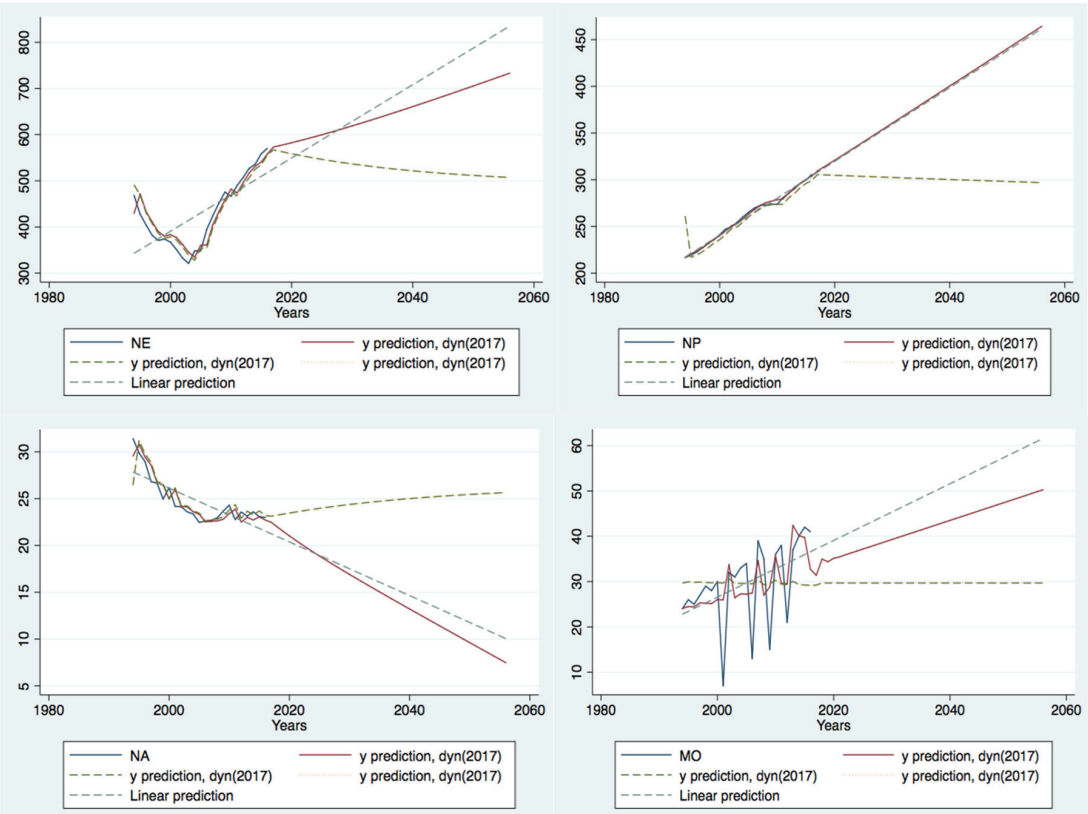

FIGURE 1 Forecasts of the Demographic Characteristics of the Population in the Republic of Macedonia (solid blue lines ending in 2016 actual values, solid red line and dashed lines - forecast values)

an increase from 18,444.5 in 1994 to 61,488.4 thousands of denars in 2016.

Expenditure for Pensions. Expenditures for pensions have increased since 1994, from 15,404.4 to 48,248.2 in thousands of denars in 2016. However, if considering the participation of the expenditures for pensions on total budget expenditure, it has decreased from $83.5 \%$ to $78.5 \%$, i.e. for five percentage points.

\section{Findings and Discussion}

Using the statistical software STATA the authors provide forecast for the individual regressors. Using arima and regression model allowed us to generate a forecast for all the variables described in the methodology.

The graphs in figure 1 present the results of the actual values and also denote the forecasted values. The graphs are grouped in financial variables and demographics. Specifically, figure 1 demonstrates the predictions of the demographic characteristics of the population in the Republic of Macedonia.

The autoregressive term has a $p$-value that is less than the significance level of 0.05. One can conclude that the coefficients for the autoregressive 
term are statistically significant, and the terms are kept in the model. The approach used is $\mathrm{AR}(1)$ model adopted to estimate the forecast of all individual regressors, starting from demographic characteristics. The employers per pensioners' data variable have the Wald chi-square 97.85 .

By using historical data for the period of 1994 until 2016 the arima $L 1$, coefficient shows significant statistical estimates at $1 \%$ level of significance for the variable employers per pensioners' data. The expected decrease in this ratio being 1.9 in $\mathbf{2 0 1 6}$ has resulted in further decrease of the forecasted values. Thus the forecasts of the employers per pensioners' data in 2056 is predicted to be 1.27 . It means that 1.27 of the employers will pay contribution for every pensioner in the Republic of Macedonia (almost 1:1) by 2056 in no reforms are undertaken on the system itself.

The same calculations are provided for the number of pensioners. For the period of 1994 until 2016 the arima L1, coefficient shows significant statistical estimates at $1 \%$ level of significance for the number pensioners data. The increase of approximately $41.2 \%$ to 305.77 thousands of pensioners in 2016, gives an expectation of further increase of the forecasted data. Accordingly, the forecasts of the number of pensioners data in 2056 is predicted to become 464.28 thousands of pensioners, indicating that there will be an increase of approximately $51.8 \%$ on the number of pensioners for the forty years of forecast in the Republic of Macedonia.

On the other hand, there was an increase on the number of employers to 570 thousands of employers in 2016. This variable has also statistical significant evidence at $1 \%$ level of significance at the lagged variable using arima. The forecasted value show evidence that in 2056 the number of employers is going to be 733 thousand, indicating that there will be an increase of approximately $28.5 \%$. The increase in the percentage points of the number of employers is less than the increase in the number of pensioners for 3.9 percentage points.

As per the natality and mortality, the forecasts based on the historical data provide sufficient statistical evidence to foresee that in the Republic of Macedonia natality will be only one third of its statistics in 2016, whereas mortality will double its value.

Figure 2 presents the financial parameters of the pension system in the Republic of Macedonia. Thus showing the following: total income, budget income, income from pension contributions and expenditures for pensions. There is a slight disparity in these indicators.

The historical data of the variable budget income showed inconsistency 

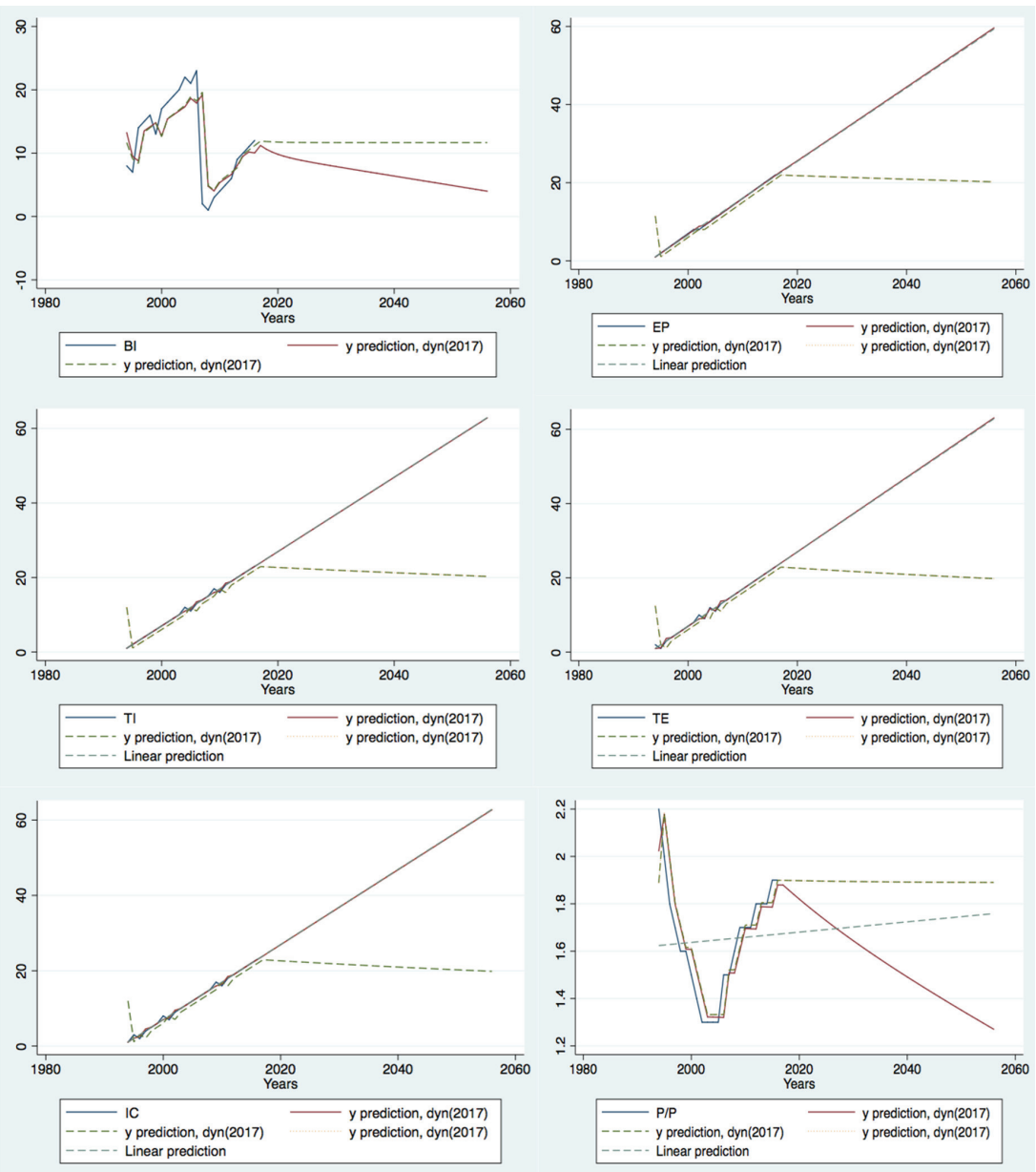

FIgURE 2 Forecasts of the Financial Parameters of the Pension System in the Republic of Macedonia (solid blue lines ending in 2016 - actual values, solid red line and dashed lines - forecast values)

by 2016. The arima $L 1$ coefficient shows significant statistical estimates at $1 \%$ level of significance for the variable employers per pensioners' data. The final result in 2056 is a decrease to one third of its value in 2016 .

Contrary to this, the total income historical data indicated an increase by 2016 . The arima $L 1$ coefficient shows significant statistical estimates at $1 \%$ level of significance for the total income variable. The forecasts of the total income in 2056 indicate that there will be an increase of approximately three times more for the forty years of forecast in the Republic of Macedonia. 
Income from pension contributions. This variable has also statistical significant evidence at $1 \%$ level of significance at the lagged variable using arima. The forecasted value show evidence that in 2056 the number of employers is going to be 733 thousand, indicating that there will be an increase of approximately $28.5 \%$. The increase in the percentage points of the number of employers is less than the increase in the number of pensioners for 3.9 percentage points.

The forecasts of expenditure for pensions, based on the historical data provide sufficient statistical evidence to foresee that in the Republic of Macedonia the expenditure for pension are increasing and thus will double its value by 2056 .

\section{Conclusion}

Taking into consideration the challenges that the pension system is facing, the key dilemma of many developed and transition countries remains precisely the direction of the development of the pension system, structure and performance. Pension reforms represent a dynamic and persistent category, which is encountered in developed, developing and transition countries. Even over the last decade, they are even more intensive, especially in terms of structure review, mobilization of resources to overcome demographic and financial difficulties, and preparation of a system that will provide a solution to the problems in the medium to long term.

Thus, pension reforms aim at realizing the rights to pension and disability insurance for all generations, short-term and long-term solvency performance, enhancing public confidence and stimulating the development of capital markets, and thus encouraging economic growth.

The reasons that led to the need for a contribution scheme could be channelled from a traditional, modern and corporate viewpoint. In traditional societies, families or communities took care of individuals who reached old age, but with its modernization people moved around communities leaving the elderly without an adequate security net. Consequently, the government underwent the provision of a type of pension system by directly supporting pensions or mandating their participation in pension plans provided by employers or private pension providers resulting from the 'myopia' and 'moral hazard' phenomenon. Whereas, according to corporate outlook, pension schemes were created as a preventive measure by the insecurity of retirement income, labour force, and the need to create an efficient saving system. 
The objectives of the pension system are often frustrated with social protection, which also addresses the challenges of poverty, vulnerability and social exclusion. However, there are substantial differences between pension and social protection in terms of administration and funding. In terms of administration, although some social protection programs may resemble pensions, yet they are not administered as a pension scheme. Social protection offers a wide range of benefits, one of which is benefit for the elderly, while pensions represent benefits that are provided by the individual by paying in a pension scheme or paid by the employer.

As far as administration is concerned, the main responsibility lies with the Ministry of Labour and Social Policy, while social security rights and services are provided through the Pension and Invalidity Insurance Fund, the Health Insurance Fund and the Employment Agency in the Republic of Macedonia.

In terms of funding, pensions are funded in various ways by contributing to a pension scheme or opening a bank account as a saving form that will play the role of retirement age, while social protection is a government program, and consequently, a special budget line is allocated for financing the programs provided by the Ministry of Labour and Social Policy. Thus, pensions are funded by the employer or by the government depending on the agreement on the use of funds, while the social protection programs are funded from the budget in the republic of Macedonia.

The need to transform the PAYG system into a fully funded pension scheme, namely the savings-investment link, resulted in the creation of a classic, neoclassical and alternative model.

Republic of Macedonia is considered to be one of the countries with the lowest contribution rate, so to achieve financial consolidation one of the recommendations would be precisely to return to the previous contribution rate of $21.2 \%$ (which is $18 \%$ currently) and increase the retirement age. This recommendation, on the one hand, would affect the growth of the number of employees, above all of the old generation, while on the other hand, will cause reduction on the number of pensioners, consequently reducing the costs.

\section{References}

Barr, N., and P. Diamond. 2006. 'The Economics of Pensions.' Oxford Review of Economics Policy 22 (1), 15-39.

Blake, D. 2006. Pension Economics. Chichester: Wiley.

Børlum, M. (2004). 'Demographic Uncertainty and the Sustainability of 
the Danish Pension System: A Stochastic Approach.' Centre for Economic and Business Research Working Paper, Copenhagen Business School, Frederiksberg.

Centre for Regional Policy Research and Cooperation 'Studiorum.' 2011. 'Effective Political Participation of the Small(er) Ethnic Communities in Local Self-Government in the Republic of Macedonia: The Impact of the Ohrid Framework Agreement.' Centre for Regional Policy Research and Cooperation 'Studiorum,' Skopje.

Chia, N., Y. Kitamura, and A. K. C. Tsui. 2004. 'The Pension System in Japan and Retirement Needs of the Japanese Elderly.' Paper presented at the Workshop on Ageing and the Status of the Older Population in Southeast Asia, Singapore, 22-23 November.

De la Fuente, A. 2011. 'A Simple Model of Aggregate Pension Expenditure.' GSE Working Paper 553, Barcelona Graduate School of Economics, Barcelona.

Dorfman, M., R. Holzmann, P. O’Keefe, D. W. Wang, Y. Sin, and R. Hinz. 2013. China's Pension System: A Vision. Washington, DC: World Bank.

Fehr, H., and C. Habermann. 2004. 'Pension Reform and Demographic Uncertainty: The Case of Germany.' Journal Pension Economic Finance 5 (1): 69-90.

Feldstein, M. S., and J. Liebman. 2001. 'Social Security.' NB E R Working Paper 8451, National Bureau of Economic Research, Cambridge, MA.

Fernandez-Diaz, F. J., C. Patxot, and G. Souto. 2013. 'Dy PEs: A Microsimulation Model for the Spanish Retirement Pension System.' Working paper 2013-06, FEDEA, Madrid.

Gora, M. 2008. 'Retirement Decisions, Benefits and the Neutrality of Pension Systems.' E NE PR I Research Report 51, Centre for European Policy Studies, Brussels.

Grech, A. G. 2010. 'Assessing the Sustainability of Pension Reforms in Europe.' PhD thesis, The London School of Economics and Political Science, London.

Hanappi, H. T., H. S. Müllbacher, and R. Winter-Ebmer. 2012. 'I H S Microsimulation Model for Retirement Behaviour in Austria.' Final report, Institute for Advanced Studies, Viena.

International Monetary Fund. 2012. Global Financial Stability Report: The Quest for Lasting Stability. Washington, DC: International Monetary Fund.

Lee, R. D., and S. Tuljapurkar. 1994. 'Stochastic Population Forecasts for the United States: Beyond High, Medium, and Low. Journal of the American Statistical Association 89 (428): 175-89.

Long, G. T., and W. D. Pfau. 2008. 'Demographic Changes and the LongTerm Pension Finances in Vietnam: A Stochastic Actuarial Assess- 
ment.' Discussion paper 08-05, GRIPS Policy Information Center, Tokyo.

Moscarola, F. C. 2009. 'Measuring the Sustainability of Pension Systems through a Microsimulation Model: The Case of Italy'. ENEPRI Research Report 66, The European Network of Economic Policy Research Institutes, n. p.

This paper is published under the terms of the Attribution-

NonCommercial-NoDerivatives 4.o International (CC B Y-NC-ND 4.0)

License (http://creativecommons.org/licenses/by-nc-nd/4.o/). 



\author{
Vpliv stilov vodenja na uspešnost podjetij na področju znanja \\ in upravljanja človeških virov \\ Ivan Miloloža
}

Znanje in človeški viri so postali središče številnih raziskav zaradi njihovega vpliva na celotno poslovanje podjetja. Poleg tega je učinkovitost upravljanja znanja in upravljanja s človeškimi viri odvisna od številnih dejavnikov. Cilj te raziskave je ugotoviti, v kolikšni meri glavne vrste vodstvenega sloga vplivajo na uspeh podjetja na področju upravljanja znanja in človeških virov. Opravljena je bila raziskava na vzorcu hrvaških podjetij in odnos med vodstvenim slogom in podjetniškim uspehom na področju znanja in upravljanja s človeškimi viri je bil preverjen $\mathrm{z}$ uporabo več linearnih regresijskih modelov.

Ključne besede: stil vodenja, upravljanje znanja, upravljanje s človeškimi viri, raziskava, linearna regresija

Klasifikacija JEL: 015

Managing Global Transitions 16 (2): 103-122

\title{
Asimetrični prehodni učinki monetarne politike na cene stanovanj v Južni Afriki \\ Andrew Phiri
}

Po nedavni finančni krizi, ki jo je spodbudil padec cen stanovanj v ZDA, so akademski krogi ponovno pokazali zanimanje za preučevanje prehodnih učinkov instrumenta denarne politike na inflacijo cen stanovanj. Ta študija preučuje asimetrično prehodnost učinkov denarne politike na inflacijo cen stanovanj v primeru Južne Afrike. V naši študiji uporabljamo avto-regresivni model $\mathrm{z}$ zagonskim pragom in ustrezen model praga korekcije napak. Iz empiričnih rezultatov je razviden negativen in pomemben prehod iz obrestnih mer v inflacijo cen stanovanj, čeprav so takšni prehodni učinki razmeroma šibki. Na splošno te ugotovitve ogrožajo sposobnost Južnoafriške banke rezerv za nadzorovanje realne inflacije cen stanovanj.

Ključne besede: nesimetrična sointegracija, instrument denarne politike, inflacija stanovanjskih cen, Južna Afrika

Klasifikacija JEL: C22, C52, E31, E52

Managing Global Transitions 16 (2): 123-140 
Časovno-frekvenčna analiza CA P M: Uporaba pri CAC 40 Roman Mestre in Michel Terraza

Ocena tržnih linij implicitno predvideva, da so njeni parametri v času nespremenljivi, ne glede na naložbeno obdobje; vlagatelji se vedejo podobno. V tem članku bomo razpravljali o tej hipotezi z uporabo tehnike signalov. Najprej bomo preverili pričakovani rezultat glede na statistične slabosti tržne linije in velikega nihanja njenih parametrov. Nato bomo uporabili signale za oceno frekvenčne beta funkcije. Pokazali smo, da klasična beta funkcija (ocenjena $\mathrm{z} \mathrm{MNK}$ ) obravnava kratkoročno beta različico. Predlagamo metodologijo, temelječo na časovno-frekvenčni analizi, ki vodi do pregleda lastnosti delnic, ki so koristne za upravljavce portfeljev.

Ključne besede: tržna linija, signali, MODW T, frekvenčne beta funkcije Klasifikacija JEL: GOO, G11, G12

Managing Global Transitions 16 (2): 141-157

\section{Vloga multidisciplinarnega in interdisciplinarnega izobraževanja v računalništvu: pregled literature}

Kari-Pekka Heikkinen in Teppo Räisänen

Težave v gospodarstvu, ki jih povzročata internetna in komunikacijska tehnologija ter njun učinek na druge industrije, so in bodo še naprej močno vplivale na obstoječe poslovne modele in proizvodnjo blaga $\mathrm{v}$ naslednjih desetletjih. Poleg tega naraščajoča kompleksnost globalnih problemov zahteva nove sposobnosti za reševanje problemov. Kompleksni reševalci problemov, znanstveni delavci, vedno bolj delujejo po principu sodelovalnih struktur, kjer $\mathrm{k}$ ustvarjanju rešitve pripomore več-profesionalni način dela. Ta študija se osredotoča na trend, kako se visokošolsko izobraževanje, zlasti na področju računalništva in inženirstva, odziva na izziv izobraževanja in podajanja sodelovalnega znanja delavcem v delovnem okolju, ki temelji na znanju. Študija je bila izvedena s pregledom literature, ki zajema publikacije, indeksirane v bibliografski podatkovni zbirki Scopus, $\mathrm{z}$ namenom najti relevantne raziskovalne članke in preglede, objavljene med letoma 2000 in 2016. Rezultati kažejo na naraščajoče zanimanje za multidisciplinarno in interdisciplinarno izobraževanje. Večina interesov se pojavlja $\mathrm{v}$ zdravstvenih, medicinskih in socialnih panogah, interesi za inženirstvo in računalništvo pa so občutno manjši. Rezultate študije lahko uporabimo za nadaljnje proučevanje neizkoriščenega potenciala inženirstva in računalništva za multidisciplinarno in interdisciplinarno izobraževanje.

Ključne besede: visokošolsko izobraževanje, interdisciplinarno, multidisciplinarno, med-strokovno, računalniški inženiring 
Klasifikacija JEL: I23, L86

Managing Global Transitions 16 (2): 159-172

Trajnost pokojninskega sistema v Republiki Makedoniji: izzivi in rešitve

Hyrije Abazi-Alili, Shpresa Alija, Abdylmenaf Bexheti, Irina B. Panovska in Remzije Rakipi

Cilj študije je oblikovati model za napovedovanje trenda stanja pokojninskega, invalidskega in invalidskega sklada Republike Makedonije. Metodologija, ki se uporablja za ocenjevanje vzdržnosti pokojninskega sistema in obvladovanje tveganja za pokojninske sklade, je napoved posameznih spremenljivk s pomočjo avto-regresivnega modela prvega reda. Ta metoda bo omogočila oceno prihodnje negotovosti prispevkov in izdatkov pokojninskega zavarovanja. Napovedani podatki kažejo, da bo v letu 2056, če se ne bo izvajalo nobene druge reforme, povečanje odstotne točke števila delodajalcev manjše od povečanja števila upokojencev za 3,9 odstotne točke. Glede natalitete in umrljivosti: v Republiki Makedoniji je predvidena le ena tretjina statistike natalitete iz leta 2016, medtem ko se bo umrljivost do leta 2056 podvojila.

Ključne besede: vzdržnost pokojnin, odložena upokojitev, prispevki in izdatki, finančne in demografske napovedi, tranzicijsko gospodarstvo Klasifikacija JEL: H55, J26, J11

Managing Global Transitions 16 (2): 173-187 